US Army Corps of Engineers $s_{\circledast}$

Engineer Research and

Development Center
ERDC

INNOVATIVE SOLUTIONS

for a safer, better world

Rapid Airfield Damage Recovery (RADR) Program

\title{
Development of an Engineering Soil Database
}

Mansour Zakikhani, Philip T. Gidley, and Jeb S. Tingle

December 2017

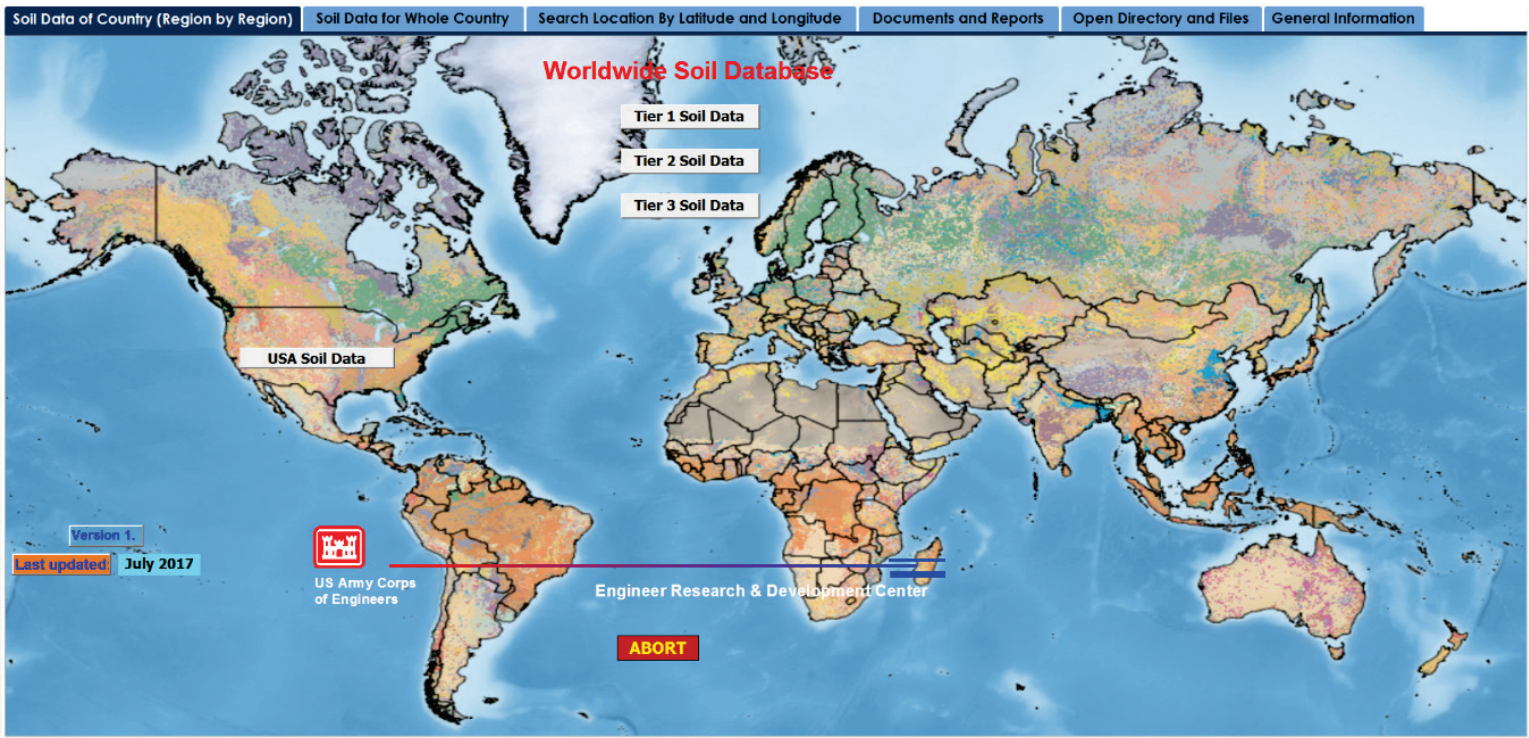


The US Army Engineer Research and Development Center (ERDC) solves the nation's toughest engineering and environmental challenges. ERDC develops innovative solutions in civil and military engineering, geospatial sciences, water resources, and environmental sciences for the Army, the Department of Defense, civilian agencies, and our nation's public good. Find out more at www.erdc.usace.army.mil.

To search for other technical reports published by ERDC, visit the ERDC online library at http://acwc.sdp.sirsi.net/client/default. 


\title{
Development of an Engineering Soil Database
}

\author{
Mansour Zakikhani and Philip T. Gidley \\ Environmental Laboratory \\ U.S. Army Engineer Research and Development Center \\ 3909 Halls Ferry Road \\ Vicksburg, MS 39180-6199 \\ Jeb S. Tingle \\ Geotechnical and Structures Laboratory \\ U.S. Army Engineer Research and Development Center \\ 3909 Halls Ferry Road \\ Vicksburg, MS 39180-6199
}

Final Report

Approved for public release; distribution is unlimited.

Prepared for Air Force Civil Engineer Center (AFCEC)

139 Barnes Drive, Tyndall AFB, FL 32403

Under Rapid Airfield Damage Recovery (RADR) Program "6JGGB2" 


\section{Abstract}

This report describes the development of a standalone engineering soil database that may be used with the design, evaluation, maintenance, and repair of airfields around the world. The soil database was developed using data from different sources. The soil data are divided into three tiers: Tier 1, Tier 2, and Tier 3. Tier 1 Data are soil data that have been measured, collected, and reported by verified U.S. Army Corps of Engineers (USACE) or U.S. Air Force (USAF) reports based on measurements and testing including the Unified Soil Classification System (USCS). Tier 2 includes data that reports USCS classification, but the data have been collected from non-verified sources such as other non-USACE reports, web sites, and published articles. Tier 3 Data includes data with alternative soil classification systems such as agricultural and geological soil classifications and soil parameters. Tier 3 Data were converted into equivalent USCS classification system. The standalone database described in this report is being converted to a web-based tool for technology transfer. At the time of publication, the database includes Tier 1 Data for 53 countries, Tier 2 data for 16 countries, and Tier 3 Data for 31 countries. The database will be updated periodically as additional data sources are identified and verified.

DISCLAIMER: The contents of this report are not to be used for advertising, publication, or promotional purposes. Citation of trade names does not constitute an official endorsement or approval of the use of such commercial products. All product names and trademarks cited are the property of their respective owners. The findings of this report are not to be construed as an official Department of the Army position unless so designated by other authorized documents. 


\section{Contents}
Abstract ii
Figures and Tables
...v
Preface. .vii
Unit Conversion Factors viii
Acronyms and Abbreviations.
ix

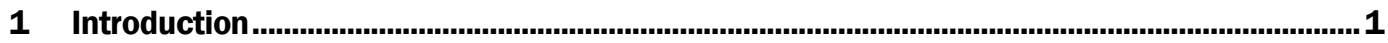

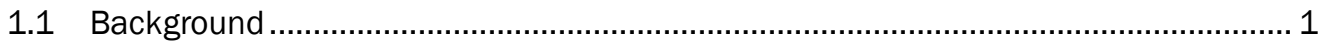

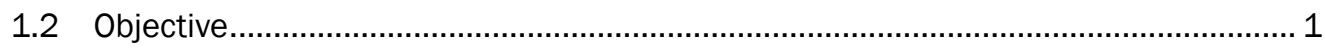

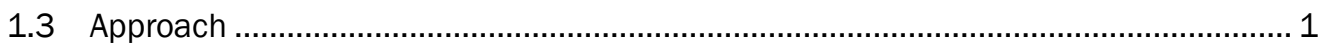

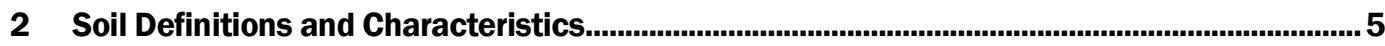

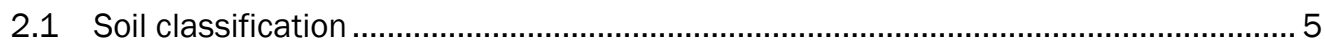

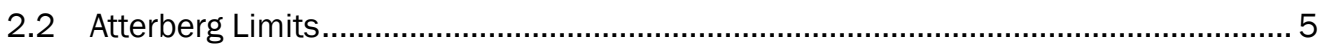

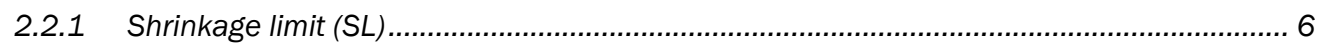

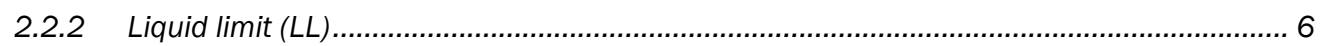

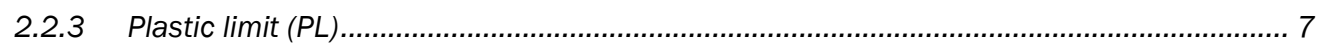

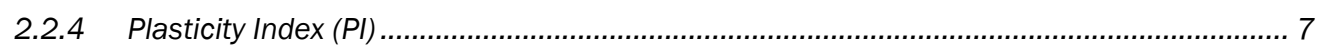

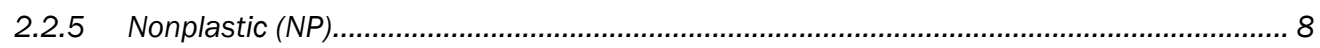

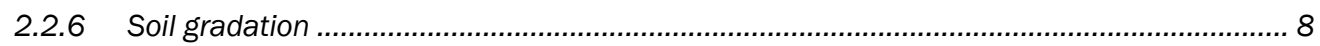

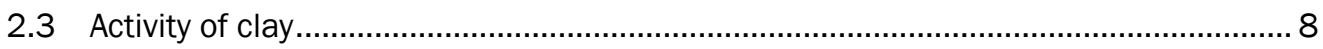

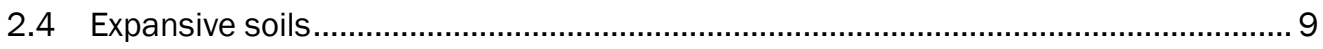

2.5 Unified Soil Classification System (USCS) ......................................................... 9

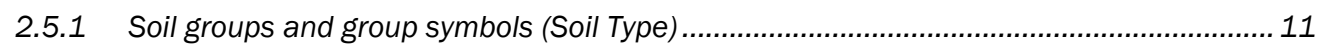

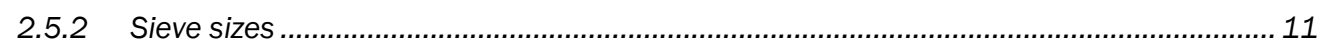

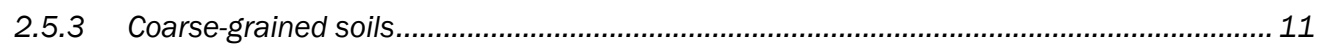

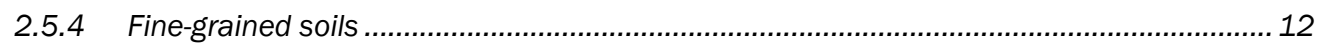

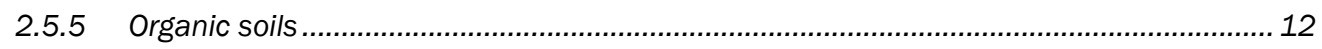

2.6 AASHTO soil classification ............................................................................ 12

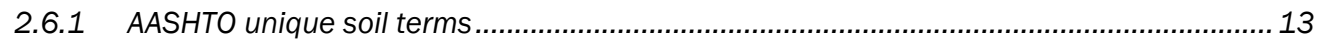

2.6.2 Comparison of AASHTO and USCS classification systems ............................................... 14

2.7 U.S. Department of Agriculture (USDA) textural soil classification ........................... 16

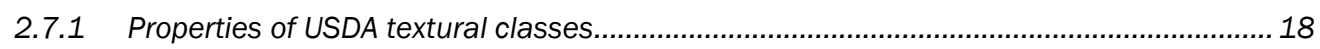

2.7.2 Size and percentage criteria for the 12 major USDA textural classes..............................19

2.8 Correlation between USDA and USCS classification.............................................20

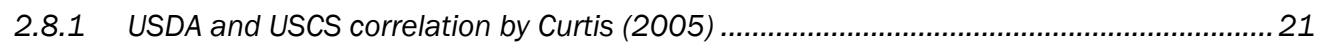

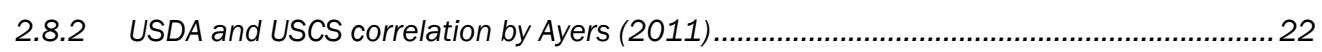

2.8.3 USDA and USCS correlation by Baylot et al. (2013) ....................................................... 23

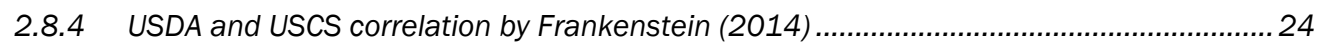

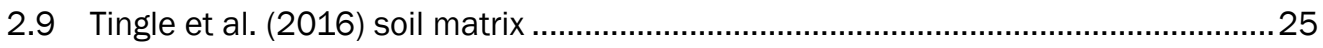


3 Soil Data Sources..............................................................................................................27

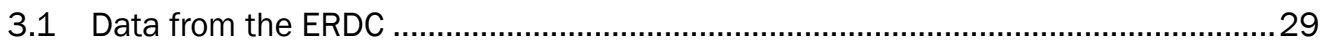

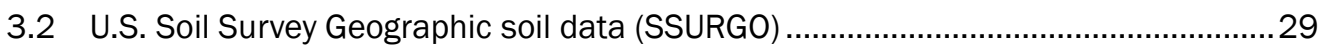

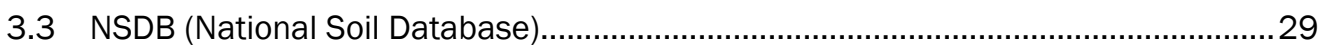

3.4 ASRIS (Australian Soil Resource Information System)...........................................30

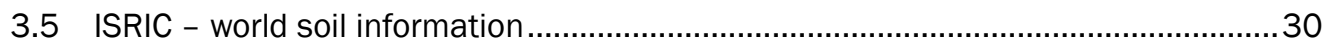

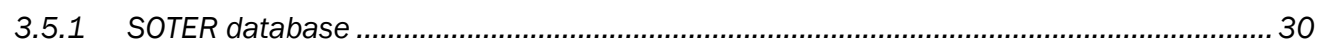

3.5.2 Harmonized World Soil Database (HWSD).................................................................. 31

3.5.3 ISRIC-WISE harmonized global soil profile dataset ........................................................... 35

3.5.4 World Reference Base (WRB) for soil resources (WRB 2006) ........................................ 36

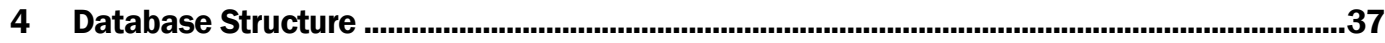

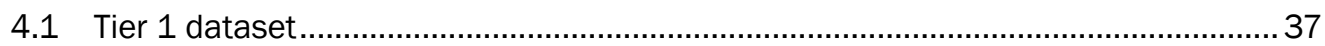

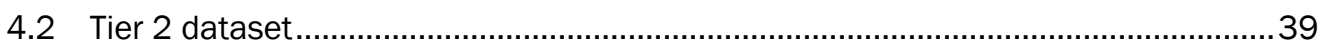

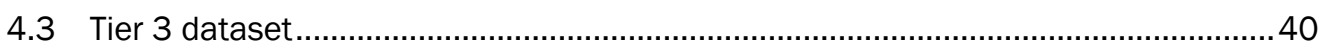

4.3.1 Converting non-USCS to USCS classification system ..................................................... 40

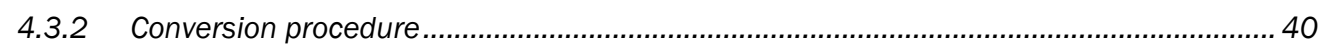

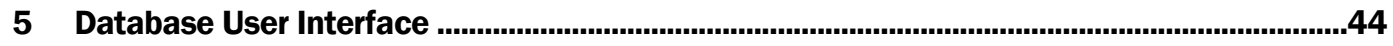

5.1 Soil data of a country (region by region) ................................................................... 44

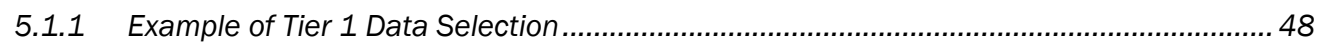

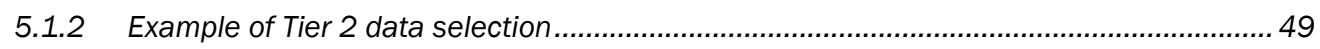

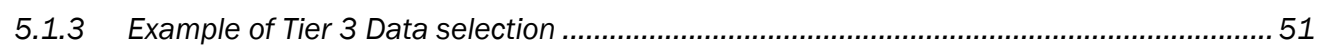

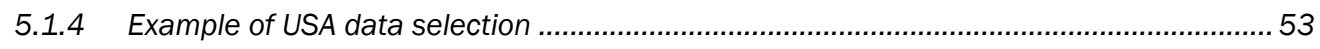

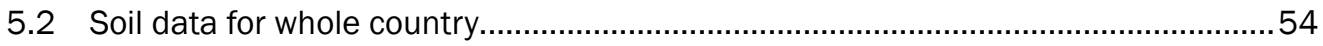

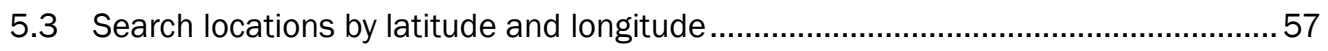

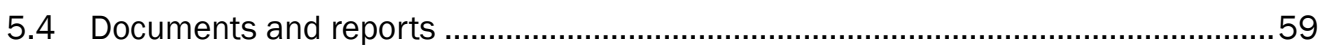

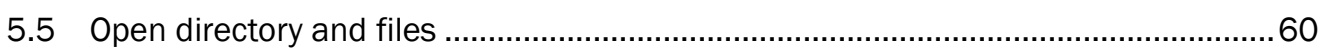

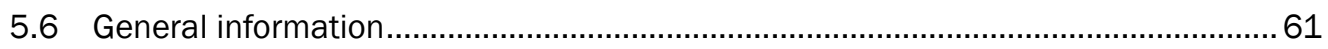

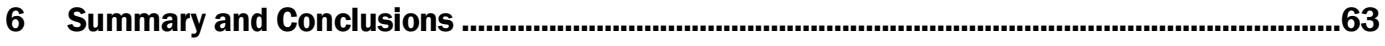

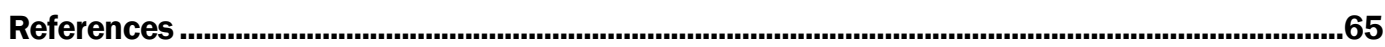

Report Documentation Page (SF 298) ........................................................................................69

Report Documentation Page 


\section{Figures and Tables}

\section{Figures}

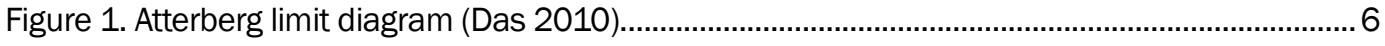

Figure 2. Liquid Limit $(L L)$ testing of the fine-grained fraction of a soil..............................................

Figure 3. USDA textural triangle for particle size distribution classes used in original data

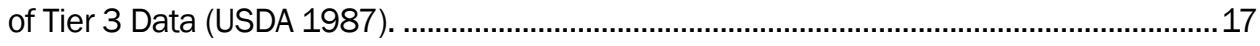

Figure 4. USCS classification mapped onto the USDA triangle by Curtis (2005)...............................21

Figure 5. USCS classification mapped onto the USDA triangle by Ayers et al. (2011). ......................22

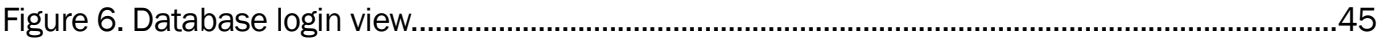

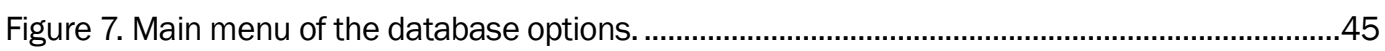

Figure 8. Tier 1 Soil Data display options. .....................................................................................46

Figure 9. Tier 2 Soil Data display options. .....................................................................................46

Figure 10. Tier 3 Soil Data display options. ...................................................................................4

Figure 11. Tier 1 USA soil data display options........................................................................... 47

Figure 12. Example of Tier 1 Data Selection...................................................................................48

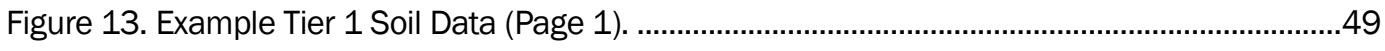

Figure 14. Example Tier 1 Soil Data (Page 2).............................................................................. 49

Figure 15. Example of Tier 2 data selection..............................................................................50

Figure 16. Example Tier 2 Soil Data (Page 1)............................................................................50

Figure 17. Tier 2 Soil Data for example data selection (Page 2)......................................................51

Figure 18. Example of Tier 3 Data selection. ...............................................................................52

Figure 19. Tier 3 Soil Data for example data selection....................................................................52

Figure 20. USA soil data selections display dialog. .....................................................................53

Figure 21. Example Tier 1 Soil Data for a site in State of Alabama, USA. .........................................54

Figure 22. Database option to select soil data for whole country...................................................55

Figure 23. Database option of Soil Data for Whole Country: View Tier 1 Data for Denmark (4 Regions, one region for each Figure below)..................................................................55

Figure 24. Display dialog of search option for a soil data location by latitude and

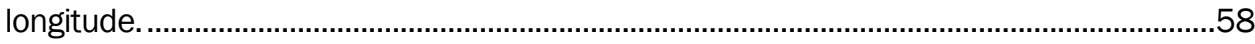

Figure 25. Search result of an example locations, location 1.......................................................58

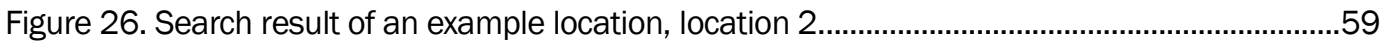

Figure 27. Display dialog of the Documents and Reports option..................................................60

Figure 28. Dialog display of Open Directory and Files option of database......................................61

Figure 29. Example of Open Directory and Files option used to open the DoD website...................61

Figure 30. A dialog display of General Information option..............................................................62

\section{Tables}

Table 1. Tier 1 Data fields in the Engineering Soil database. ........................................................... 2

Table 2. Plasticity Index (PI) range (Das and Sobhan 2014) ............................................................ 7 
Table 3. Typical activity number of different clay minerals (Das 2016)..............................................

Table 4. USCS group soil groups and group symbols.....................................................................

Table 5. Sieve designation and size of openings (USDA 1990).......................................................11

Table 6. Classification of AASHTO subgrade materials (Das and Sobhan 2014)..............................13

Table 7. Comparison of the AASHTO system with the USCS (Das and Sobhan 2014)......................15

Table 8. Comparison of the USCS with the AASHTO system (Das and Sobhan 2014).......................15

Table 9. A comparison of the reactions of three soil separates to certain behavioral properties based on USDA particle size class (USDA 1987)............................................19

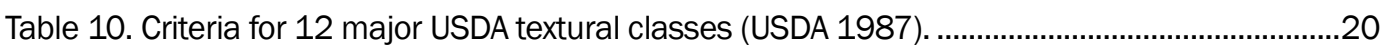

Table 11. USCS fit for USDA based on Ayers et al. (2011) data (Garcia-Gaines and

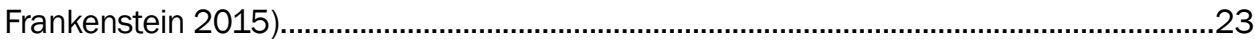

Table 12. Soil classification group conversion (Baylot et al. 2013).....................................................23

Table 13. USDA classification equivalency in USCS classification (Frankenstein 2014). ..................24

Table 14. USCS and other soil classification systems (Tingle et al. 2016)........................................26

Table 15. Recommended codes for the reference soil groups (WRB 2006)....................................31

Table 16. Conversion procedure from USDA to USCS classification. ...................................................40 


\section{Preface}

This study was conducted for the U.S. Air Force Civil Engineer Center under the Rapid Airfield Damage Recovery (RADR) Program.

This work was performed by the Water Quality and Environmental Modeling Branch (WQMB) of the Environmental Processes and Engineering Division (EP), U.S. Army Engineer Research and Development Center-Environmental Laboratory (ERDC-EL). At the time of publication, Mr. Mark R. Noel was Chief, CEERD-WQCMB; Mr. Warren Lorentz was Chief, CEERD-EP; Dr. Jack E. Davis was Deputy Director of ERDC-EL; and Dr. Beth Fleming was Director, ERDC-EL.

The authors express appreciation to Mr. Danny W. Harrelson, Dr. Ernest S. Berney, Mr. Seth M. Martin, Ms. Maria T. Stevens, the U.S. Army Engineer Research and Development Center-Geotechnical and Structures Laboratory (ERDC-GSL), and many other engineers and scientists for providing valuable data and information that were used to develop the database.

COL Bryan S. Green was the Commander of ERDC, and Dr. David W. Pittman was the Director. 


\section{Unit Conversion Factors}

\begin{tabular}{|c|c|c|}
\hline Multiply & By & To Obtain \\
\hline acres & $4,046.873$ & square meters \\
\hline acre-feet & $1,233.5$ & cubic meters \\
\hline cubic feet & 0.02831685 & cubic meters \\
\hline cubic inches & 1.6387064 E-05 & cubic meters \\
\hline cubic yards & 0.7645549 & cubic meters \\
\hline degrees (angle) & 0.01745329 & radians \\
\hline degrees Fahrenheit & $(\mathrm{F}-32) / 1.8$ & degrees Celsius \\
\hline feet & 0.3048 & meters \\
\hline foot-pounds force & 1.355818 & joules \\
\hline gallons (US liquid) & 3.785412 E-03 & cubic meters \\
\hline hectares & $1.0 \mathrm{E}+04$ & square meters \\
\hline inches & 0.0254 & meters \\
\hline inch-pounds (force) & 0.1129848 & newton meters \\
\hline miles (nautical) & 1,852 & meters \\
\hline miles (US statute) & $1,609.347$ & meters \\
\hline miles per hour & 0.44704 & meters per second \\
\hline
\end{tabular}




\section{Acronyms and Abbreviations}

\begin{tabular}{|c|c|}
\hline Term & Definition \\
\hline AASHTO & American Association of State Highway and Transportation Officials \\
\hline ACS & Airfield Classification System \\
\hline AFWA & Air Force Weather Agency \\
\hline ASRIS & Australian Soil Resource Information System \\
\hline ASTM & American Society for Testing and Materials \\
\hline BSCS & British Soil Classification System \\
\hline CBR & California Bearing Ratio \\
\hline $\mathrm{CD}$ & Compact disk \\
\hline DoD & U.S. Department of Defense \\
\hline ERDC & U.S. Army Engineer Research and Development Center \\
\hline ESDB & European Soil Database \\
\hline FAO & Food and Agriculture Organization (of the United Nations) \\
\hline FASST & Fat All-Season Soil Strength \\
\hline GI & Group index \\
\hline GSL & Geotechnical and Structural Laboratory \\
\hline GUI & Graphical User Interface \\
\hline HWSD & Harmonized World Soil Database \\
\hline ISRIC & International Soil Reference and Information Centre \\
\hline ISSS & International Soil Science Society \\
\hline IUSS & International Union of Soil Sciences \\
\hline LL & Liquid Limit \\
\hline NATO & North Atlantic Treaty Organization \\
\hline NP & Nonplastic \\
\hline NRMM & NATO Reference Mobility Model \\
\hline NSDB & National Soil Database (Canada) \\
\hline OMB & Office of Management and Budget \\
\hline PGI & Partial Group Index \\
\hline PI & Plasticity Index \\
\hline PL & Plastic Limit \\
\hline RADR & Rapid Airfield Damage Recovery \\
\hline RSG & Reference Soil Group \\
\hline SL & Shrinkage limit \\
\hline SOTER & Soil and Terrain (database for Latin America and the Caribbean) \\
\hline SSURGO & US Soil Survey Geographic \\
\hline UNEP & United Nations Environmental Program \\
\hline UNESCO & United Nations Educational, Scientific and Cultural Organization \\
\hline USACE & United States Army Corps of Engineers \\
\hline USAF & United States Air Force \\
\hline USCS & Unified Soil Classification System \\
\hline USDA & U.S. Department of Agriculture \\
\hline WQMB & Water Quality and Environmental Modeling Branch \\
\hline WRB & World Reference Base \\
\hline
\end{tabular}




\section{Introduction}

\subsection{Background}

U.S. Air Force (USAF) engineer units are charged with the design, evaluation, maintenance, and repair of airfields around the world. Most projects require engineer units to work with different local soils to complete their projects. Project planners often need information on the local soils to understand materials they will encounter and have as available resources. While laboratory testing facilities are available in many deployed locations, the ability to rapidly characterize local soils and relate those characteristics to expected engineering behavior is limited. Often, it is desirable to assess site conditions before assets are ever developed.

\subsection{Objective}

There are several worldwide soils databases with different soil characteristics available within the U.S. Department of Defense (DoD). However, none of the databases are comprehensive in regards to engineering properties. Most of the databases are very specific to one aspect of soil behavior, and few of these databases exist in a searchable electronic format. A comprehensive soils database has been needed to provide basic soil geographic distribution, soil properties, and engineering characteristics to help planners and engineers conduct military projects globally.

\subsection{Approach}

A worldwide engineering soil database has been developed containing different quality soil data, or tiers. The data have been ranked into three tiers: Tier 1, Tier 2, and Tier 3. The data sources for Tier 1 Soil Data are from the United States Army Corps of Engineers (USACE) or USAF reports that have been archived at the U.S. Army Engineer Research and Development Center (ERDC) and databases that were available from other ERDC laboratories. Tier 1 Data are soil data that have been measured, collected, and reported by trusted DoD sources. This data are based on field and laboratory measurements, testing, and having Unified Soil Classification System (USCS) engineering grouping system. Tier 2 data have USCS classification information, but they have been collected from 
non-DoD sources such as other nations' reports, web sites, and published articles. Tier 2 data have enough soil characterization data to indicate proper and consistent classification based on the USCS. Tier 3 Data were collected from data sources and databases that have classification systems such as agricultural and geological classifications data and were converted with our database into equivalents within the USCS classification system.

The database developed here provides the soil data with USCS classification system. Only Tier 3 Data were converted from non-USCS data to the USCS soil classification system using scientific and engineering assumptions and formulations. At the time of this publication, the database has Tier 1 Data for 53 countries, including Tier 1 Data for all states of the U.S. The Tier 2 data are available for 16 countries, and Tier 3 Data are available for 31 countries. The user should check for updated databases, which will have soil data for more countries and locations.

Tier 1 Data include typical USCS parameters and other parameters of interest for planning of construction projects such as California Bearing Ratio (CBR), $k$ (Modulus of subgrade reaction), Density, Moisture, liquid Limit ( $L L$ ), Plasticity Index (PI), \% Passing \# 200, aggregate properties, etc. (Table 1).

Table 1. Tier 1 Data fields in the Engineering Soil database.

\begin{tabular}{|c|c|c|}
\hline Field Name & Data Type & Description \\
\hline ID & AutoNumber & \\
\hline ID Region & Number & ID for Country Region or Data Location \\
\hline Country Code & Short Text & Two Letters Country Code \\
\hline Country Region & Short Text & Name of Site, Airport, Road etc. (Needs to be Updated) \\
\hline Nearest City & Short Text & Name of city that is served by the airport \\
\hline Latitude Region & Short Text & General Latitude of the site \\
\hline Longitude Region & Short Text & General Longitude of the site \\
\hline Description & Short Text & A general description of the subgrade soils \\
\hline Classification System & Short Text & Classification system, for example: USCS \\
\hline Soil Type & Short Text & Classification code or value \\
\hline CBR (\%) & Short Text & $\begin{array}{l}\text { Conservative design value for the California Bearing } \\
\text { Ratio }\end{array}$ \\
\hline Average CBR (\%) & Short Text & Average CBR of several values of the subgrade \\
\hline Minimum CBR (\%) & Short Text & Minimum CBR of the subgrade measured at the site \\
\hline
\end{tabular}




\begin{tabular}{|c|c|c|}
\hline Field Name & Data Type & Description \\
\hline Maximum CBR (\%) & Short Text & Maximum CBR of the subgrade measured at the site \\
\hline CBR Method & Short Text & Method used to determine CBR \\
\hline Soaked Field CBR (\%) & Short Text & Value for the field soaked CBR of the subgrade \\
\hline Min Soaked Field CBR (\%) & Short Text & Minimum field soaked CBR of the subgrade \\
\hline Max Soaked Field CBR (\%) & Short Text & Minimum field soaked CBR of the subgrade \\
\hline Unsoaked Field CBR (\%) & Short Text & Value of field unsoaked CBR of the subgrade at the site \\
\hline Min Unsoaked Field CBR (\%) & Short Text & Minimum field unsoaked CBR of the subgrade \\
\hline Max Unsoaked Field CBR (\%) & Short Text & Maximum field unsoaked CBR of the subgrade \\
\hline Lab CBR (\%) & Short Text & Value for the laboratory CBR of the subgrade \\
\hline 100\% Lab CBR (\%) & Short Text & Value for the laboratory $100 \%$ CBR of the subgrade \\
\hline 95\% Lab CBR (\%) & Short Text & Value for the laboratory $95 \%$ CBR of the subgrade \\
\hline 90\% Lab CBR (\%) & Short Text & Value for the laboratory $90 \%$ CBR of the subgrade \\
\hline k (pci) & Short Text & Modulus of subgrade reaction \\
\hline Minimum k (pci) & Short Text & Minimum $\mathrm{k}$ value at the site \\
\hline Maximum k (pci) & Short Text & Maximum $\mathrm{k}$ value at the site \\
\hline Dry Density (pcf) & Short Text & Average dry weight density of the subgrade \\
\hline Gravimetric Moisture Content (\%) & Short Text & Engineering gravimetric moisture content in \% \\
\hline Subgrade Aggregate Properties & Short Text & Aggregate properties of the subgrade, e.g., hardness \\
\hline $\begin{array}{l}\text { Construction Aggregate } \\
\text { Properties }\end{array}$ & Short Text & Aggregate properties in the surrounding area \\
\hline Liquid Limit (\%) & Short Text & Average liquid limit for the subgrade at the site \\
\hline Plasticity Index (\%) & Short Text & Average plasticity index for the subgrade at the site \\
\hline \% Passing \#200 sieve & Short Text & Range of values (units in \%) passing a \#200 sieve \\
\hline Short Reference & Short Text & Short reference of the source of the data \\
\hline Long Reference & Short Text & Long reference for the source of the data \\
\hline
\end{tabular}

The first version of the database described in this report was developed as a Microsoft Access 2013 database. The soil data were stored in MS Excel ${ }^{\circledR}$ tables integrated in a database (interface). Microsoft Access was chosen because of its availability and versatility as a relational database application. The current MS Access ${ }^{\circledR}$ database can be accessed only by compact disk (CD) distribution and assigned username and password. The software is standalone and can be installed on desktops or laptops. The database provides digital (tables or reports) information for specific locations based on a country and regional selection identified by the latitude and longitude of the location. 
The database will be gradually expanded over time to include soil data for all countries. However, the database must remain portable and userfriendly. The MS Access ${ }^{\circledR}$ database is versatile for future developments and web-based applications as explained below.

The end users of the database are military troops (especially, USAF staff) that would need to gather intelligence for a decision brief regarding an operation in whatever area of the world they are concerned about. Other users would include other DoD engineers with a need for basic soil information. The goal for the database is also to integrate disparate DoD databases. The database is *.mil restricted at this time. Ultimately, the database will be migrated to a web-based tool for DoD users to log into and access using a graphical user interface (GUI) to search whatever area of the world they are interested, identify the types of data (Tier 1, Tier 2, or Tier 3) available for that area, and select from a list of available soil data for compiling in a printable table/summary. The database will be continuously expanded and include high quality data (Tier 1) as well as lower-quality (Tier 2 and Tier 3) data along with the algorithms that convert other classification systems into USCS. 


\section{Soil Definitions and Characteristics}

\subsection{Soil classification}

Soil classification is the separation of different types of soil into classes or groups, each having similar characteristics and potentially similar behavior. Soil classification systems can be divided into two main divisions, one for soil science and one for engineering purposes. For engineering purposes, soil classification systems divide soils into groups and subgroups based on engineering properties such as grain size distribution, LL, and Plastic Limit (PL). The two major classification systems presently in use for engineering purposes are (1) The American Association of State Highway and Transportation Officials (AASHTO) soil classification system and (2) the USCS. The AASHTO system is used mainly for the classification of soils for highway projects. The USCS is a derivation of some of the earliest classification systems, and the predominant system used by the DoD. For reasons of practical use, this project focused mainly on the USCS system because a global relation between the classification and the behavior of the material has been developed. The database described within provides USCS soil parameters or converts alternative soil data into an equivalent USCS classification. The USCS system classifies a soil sample according to the following field and laboratory tests or terms.

\subsection{Atterberg Limits}

The Atterberg Limits are a basic measure of the critical water contents of a fine-grained soil to include shrinkage limit, $P L$, and liquid limit. As a dry, fine-grained soil takes on increasing amounts of water, it undergoes distinct changes in behavior and consistency (Figure 1). These limits were introduced by Albert Atterberg, a Swedish agriculturist. They were later refined by Casagrande (1948) and ultimately used in the USCS to differentiate the behavior of fine-grained soils.

A study of the Atterberg Limits of different clays has shown that the ratio of the $L L$ to the $P L$ defines the type of clay present in a soil. This ratio $R$ (or plasticity ratio) is shown to be related exponentially to Skempton's Activity (Skempton 1953). Skempton suggested three classes of clays according to activity: (a) inactive for activities less than 0.75; (b) normal for activities 
between 0.75 and 1.25, and (c) active for activities greater than 1.25. Active clays provide the most shrink-swell potential (ASTM D-4318). More description on the activity of clay, which is an essential part of the methodology used for Tier 3 conversion of alternative soil data, is provided below.

Figure 1. Atterberg limit diagram (Das 2010).

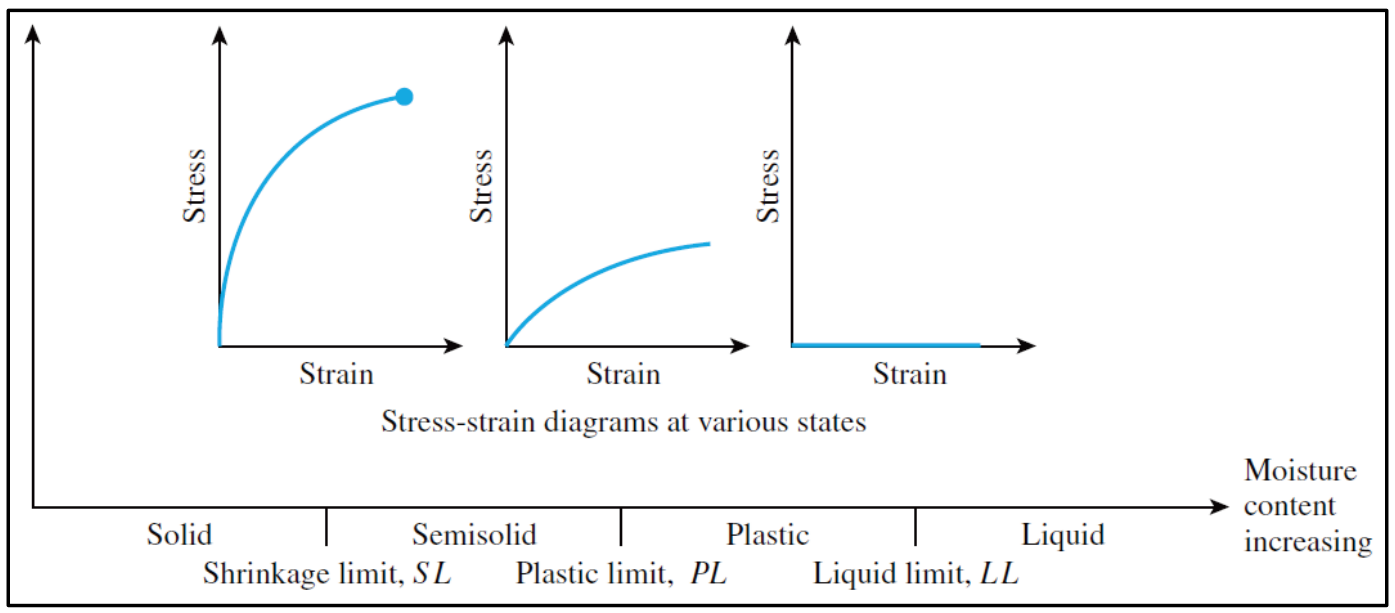

\subsubsection{Shrinkage limit (SL)}

The $S L$ of a soil is the water content, expressed as a percentage of the weight of the oven-dried soil, at which further loss in moisture will not cause a decrease in its volume. As part of the $S L$ test, the shrinkage ratio and linear shrinkage are also usually determined. The shrinkage ratio is defined as the ratio between a given volume change and the corresponding change in water content above the $S L$. The linear shrinkage is defined as the decrease in one dimension of a soil mass, expressed as a percentage of the original dimension, when the water content is reduced from a given value to the $S L$. This defines the limit between the solid and semisolid states of consistency.

\subsubsection{Liquid limit (LL)}

The $L L$ is the water content corresponding to the arbitrary limit between the liquid and plastic states of a soil's consistency. This is the water content at which a part of soil, cut by a groove 2 millimeters $(\mathrm{mm})$ wide (5/64 inch [in.]), will flow together for a distance of $13 \mathrm{~mm}(1 / 2 \mathrm{in}$.) under the impact of 25 blows in a standard liquid limit apparatus. Figure 2 shows an $L L$ testing of the fine-grained fraction of a soil. 
Figure 2. Liquid Limit ( $L L)$ testing of the fine-grained fraction of a soil.

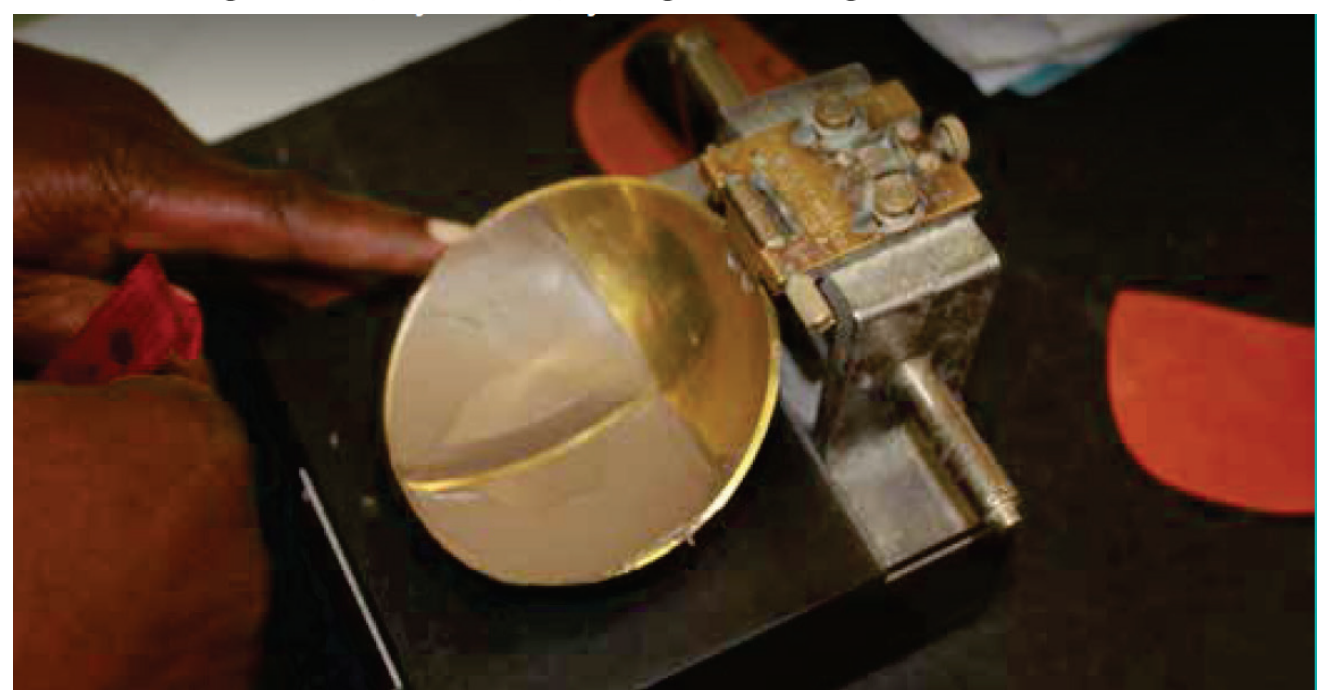

\subsubsection{Plastic limit $(P L)$}

The boundary between the plastic and the solid state of the soil is called the $P L$. The $P L$ is the moisture content at which the soil will just begin to crumble when rolled into a threads with a diameter of $3 \mathrm{~mm}$ (1/8 in.).

\subsubsection{Plasticity Index (PI)}

The $P I$ is a measure of the plasticity of a soil. The plasticity index is the size of the range of water contents where the soil exhibits plastic properties. The $P I$ is the difference between the $L L$ and the $P L(P I=L L-P L)$. Table 2 provides a qualitative numbers of $P I$.

Table 2. Plasticity Index $(P)$ range (Das and Sobhan 2014).

\begin{tabular}{|l|l|}
\hline Plasticity Index (PI) (\%) & Description \\
\hline 0 & Nonplastic \\
\hline $1-5$ & Slightly plastic \\
\hline $5-10$ & Low Plasticity \\
\hline $10-20$ & Medium plasticity \\
\hline $20-40$ & High plasticity \\
\hline$>40$ & Very high plasticity \\
\hline
\end{tabular}




\subsubsection{Nonplastic (NP)}

For soil that the $L L$ or $P L$ cannot be determined, or the $P L$ is equal to or greater than the $L L$, the soil is termed non-plastic.

\subsubsection{Soil gradation}

The size and shape of the soil particles describe properties of the individual grains in a soil mass. Soil gradation provides information on the distribution of the different size groups within a soil. The soil may be well $(\mathrm{W})$ or poorly $(\mathrm{P})$ graded depending on the distribution of particle sizes within the soil mass. To be classified as $\mathrm{W}$, a soil must have a good range of all representative particle sizes between the largest and the smallest. All sizes must be represented, and no one size should be either overabundant or missing. $\mathrm{P}$ soils are either those containing a narrow range of particle sizes or those with some intermediate sizes lacking. Soils with a limited range of particle sizes are called uniformly graded. Soils that have some intermediate size or sizes not well represented or missing are called gap graded, step graded, or skip graded.

\subsection{Activity of clay}

The mineralogy of clay has direct relation with its geotechnical parameters (Mukherjee 2013). The ratio of the plasticity index to the clay fraction content is approximately constant, and may be defined as the activity of the clay (A) (Skempton 1953; Equation 1). Values of activity are given for many clays and also for the more common minerals. It is shown that activity is related to the mineralogy and geological history of clays and to the proportion of their shear strength contributed by true cohesion. The activity value is an essential part of the methodology used to convert alternative soil data into Tier 3 Data and were needed in addition to other soil information to convert non-USCS data to USCS data.

$$
A=\frac{\text { plasticity index }(P I)}{\text { clay fraction }}
$$

Table 3 lists typical activity values for different clay minerals. 
Table 3. Typical activity number of different clay minerals (Das 2016).

\begin{tabular}{|l|l|l|l|}
\hline Mineral & Liquid limit, LL & Plastic limit, PL & Activity A \\
\hline Kaolinite & $35-100$ & $20-40$ & $0.3-0.5$ \\
\hline Illite & $60-120$ & $35-60$ & $0.5-1.2$ \\
\hline Montmorillonite & $100-900$ & $50-100$ & $1.5-7.0$ \\
\hline Halloysite (hydrated) & $50-70$ & $40-60$ & $0.1-0.2$ \\
\hline Halloysite (dehydrated) & $40-55$ & $30-45$ & $0.4-0.6$ \\
\hline Attapulgite & $150-250$ & $100-125$ & $0.4-1.3$ \\
\hline Allophane & $200-250$ & $120-150$ & $0.4-1.3$ \\
\hline
\end{tabular}

\subsection{Expansive soils}

Expansive soil is soil that is prone to large volume changes (swelling and shrinking) that are directly related to changes in water content. When an expansive soil is compacted, it will not retain its density as an increase in moisture content will cause it to swell and thus lose density. This is undesirable in most engineering applications. There are laboratory tests designed specifically to measure the expansion potential of a particular soil sample. By adding water to the sample while measuring its deformation, the soils engineer will compare the result to a scale or expansion index. The American Society of Testing Materials (ASTM D-4829) has published a test method and an expansion index to quantify the results. The expansion index range and potential expansion are as follows: $0-20$ : Very Low; 21-50: Low; 51-90: Medium; 91-130: High; >130: Very High.

\subsection{Unified Soil Classification System (USCS)}

Several soil classifications have been developed based on properties of soils such as texture, plasticity, strength, and other characteristics. A few classification systems have gained fairly wide acceptance. Normally, a single soil classification does not provide the complete information on a soil that the engineer needs. The USCS of soils, however, has been developed to provide a simple classification system of the properties of a given soil that can be used by the engineers. The USCS classification was developed to broadly distinguish between behaviors of the different material.

The USCS classification of soils is based on a combination of visual observation and laboratory tests. The USCS classifies soils according to 
their textural and plasticity qualities and on their grouping with respect to behavior. The USCS is based on those characteristics of the soil that indicate how it will behave as an engineering construction material. ASTM D-2487-11 provides information on visual and field classification of soil sample for USCS. Table 4 provides a list of the USCS soil types.

Table 4. USCS group soil groups and group symbols.

\begin{tabular}{|c|c|c|c|c|}
\hline $\begin{array}{l}\text { Primary } \\
\text { divisions }\end{array}$ & & & Group symbol & Descriptions \\
\hline \multirow{8}{*}{$\begin{array}{l}\text { COARSE-GRAINED } \\
\text { SOILS } \\
\text { Sands } \\
\text { Gravels } \\
\text { Over } 50 \% \text { retained } \\
\text { on \#200 sieve }\end{array}$} & \multirow{4}{*}{$\begin{array}{l}\text { GRAVELS } \\
\text { Over } 50 \% \text { of } \\
\text { coarse } \\
\text { material } \\
\text { retained on } \\
\text { \#4 sieve }\end{array}$} & \multirow{2}{*}{$\begin{array}{l}\text { CLEAN } \\
\text { GRAVEL } \\
\text { Less than } \\
5 \% \text { passing } \\
\text { \#200 sieve }\end{array}$} & GW & $\begin{array}{l}\text { Well graded gravel, many } \\
\text { different particle sizes, little or } \\
\text { no fines }\end{array}$ \\
\hline & & & GP & $\begin{array}{l}\text { Poorly graded, few different } \\
\text { particle sizes, little or no fines }\end{array}$ \\
\hline & & \multirow{2}{*}{$\begin{array}{l}\text { GRAVEL } \\
\text { WITH FINES }\end{array}$} & GM & $\begin{array}{l}\text { Silty gravels, gravel-sand-silt } \\
\text { mixtures }\end{array}$ \\
\hline & & & $\mathrm{GC}$ & $\begin{array}{l}\text { Clayey gravels, gravel-sand-clay } \\
\text { mixtures }\end{array}$ \\
\hline & \multirow{4}{*}{$\begin{array}{l}\text { SAND } \\
\text { Over } 50 \% \text { of } \\
\text { coarse } \\
\text { material } \\
\text { passed \#4 } \\
\text { sieve }\end{array}$} & \multirow{2}{*}{$\begin{array}{l}\text { CLEAN } \\
\text { SANDS } \\
\text { Less than } \\
5 \% \text { passing } \\
\text { \#200 sieve }\end{array}$} & SW & $\begin{array}{l}\text { Well graded gravel, many } \\
\text { different particle sizes, little or } \\
\text { no fines }\end{array}$ \\
\hline & & & SP & $\begin{array}{l}\text { Poorly graded, few different } \\
\text { particle sizes, little or no fines }\end{array}$ \\
\hline & & \multirow{2}{*}{$\begin{array}{l}\text { SAND WITH } \\
\text { FINES }\end{array}$} & SM & $\begin{array}{l}\text { Silty gravels, gravel-sand-silt } \\
\text { mixtures }\end{array}$ \\
\hline & & & SC & $\begin{array}{l}\text { Clayey gravels, gravel-sand-clay } \\
\text { mixtures }\end{array}$ \\
\hline \multirow{6}{*}{$\begin{array}{l}\text { FINE-GRAINED } \\
\text { SOILS } \\
\text { Silts } \\
\text { Clays } \\
\text { (Over } 50 \% \text { passing } \\
\text { the \#200 sieve) }\end{array}$} & \multirow{3}{*}{\multicolumn{2}{|c|}{$\begin{array}{l}\text { Silts and Clays } \\
\text { Liquid limit less than } \\
50\end{array}$}} & ML & $\begin{array}{l}\text { Inorganic silts, slight to no } \\
\text { plasticity }\end{array}$ \\
\hline & & & $\mathrm{CL}$ & $\begin{array}{l}\text { Inorganic clays, low to moderate } \\
\text { plasticity }\end{array}$ \\
\hline & & & $\mathrm{OL}$ & $\begin{array}{l}\text { Organic silts and clays of low } \\
\text { plasticity }\end{array}$ \\
\hline & \multirow{3}{*}{\multicolumn{2}{|c|}{$\begin{array}{l}\text { Silts and Clays } \\
\text { Liquid limit } 50 \text { or more }\end{array}$}} & $\mathrm{MH}$ & $\begin{array}{l}\text { Inorganic silts, moderate to high } \\
\text { plasticity }\end{array}$ \\
\hline & & & $\mathrm{CH}$ & $\begin{array}{l}\text { Inorganic clays, high plasticity, } \\
\text { fat clays }\end{array}$ \\
\hline & & & $\mathrm{OH}$ & $\begin{array}{l}\text { Organic silts and clays of high } \\
\text { plasticity }\end{array}$ \\
\hline Highly organic soils & \multicolumn{2}{|c|}{$\begin{array}{l}\text { Primary organic matter, dark } \\
\text { in color, and organic odor }\end{array}$} & PT & Peat \\
\hline
\end{tabular}




\subsubsection{Soil groups and group symbols (Soil Type)}

Under the USCS, soils are primarily identified as coarse-grained, finegrained, and highly organic. On a textural basis, coarse-grained soils are those that have 50 percent or more by weight of the overall soil sample retained on the No. 200 sieve, fine-grained soils are those that have more than 50 percent by weight passing the No. 200 sieve. Organic soils, like top soil and peat, exhibit an odor. These odors are indicative of decaying vegetation and other organic matter. These soils should be avoided for anything related to construction except for landscaping applications. The coarse-grained soils are subdivided into gravel and gravelly soils (G) and sands and sandy soils (S). Fine-grained soils are subdivided on the basis of their Atterberg Limits. The symbol $L$ is used for soils with $L L s$ of 50 and less, and the symbol $H$ for soils with $L L$ s in excess of 50 . Peat and other highly organic soils are designated by the symbol $P t$.

\subsubsection{Sieve sizes}

U.S. sieve sizes are used in describing soil groups. Table 5 provides a list of U.S. standard sieve sizes and their opening sizes.

Table 5. Sieve designation and size of openings (USDA 1990).

\begin{tabular}{|c|c|c|}
\hline U.S. standard sieve sizes & Size of opening in $\mathrm{mm}$ & Size of opening in inches \\
\hline $3^{\prime \prime}$ & 75.0 & 3 \\
\hline $3 / 4^{\prime \prime}$ & 19.0 & $3 / 4$ \\
\hline$\# 4$ & 4.75 & $3 / 16$ \\
\hline$\# 10$ & 2.00 & - \\
\hline$\# 40$ & 0.425 & - \\
\hline$\# 200$ & 0.075 & - \\
\hline
\end{tabular}

\subsubsection{Coarse-grained soils}

Coarse-grained material are divided into two groups, $\mathrm{S}$ or G. If over 50 percent of soil sample would pass the \#4 sieve (Table 3), then the soil sample is a sand (first letter is S). If less than $50 \%$ of soil sample would pass the \#4 sieve, then the soil sample is a gravel (first letter is G).

After grouping the soil into either the G or S category, the sample is tested for percentage of fine material to check whether it has less than or more 
than $5 \%$ fines. If the sample has more than $5 \%$ fine particles, the type of fines must be examined. If the fines are primarily clay, then the second letter of the classification is $\mathrm{C}$. If the fines are silt (non-plastic) then the second letter is M.

If all the particle sizes of a sample of coarse-grained soil appear to be approximately the same, then it is a poorly graded soil (second letter is P). If a wide range of particle sizes is present, then the sample is a well graded soil (second letter is W).

\subsubsection{Fine-grained soils}

The fine-grained soil materials consist of silts $(M)$ and clays $(C)$. The primary piece of information in field classification of silts and clays is the level of stickiness, or cohesion present in the soil. A low-plasticity soil, probably is a silt $(M L)$, a moderately plastic soil is moderate plastic clay $(\mathrm{CL})$, and a highly plastic soil is either a highly plastic clay $(\mathrm{CH})$ or a highly plastic silt $(M H)$. Organic silts and clays are classified as $O L$ and $O H$.

\subsubsection{Organic soils}

Highly organic soils, like top soil and peat, should be avoided for anything related to construction except for landscape areas. These soils are classified as Peat (Pt).

\subsection{AASHTO soil classification}

The AASHTO soil classification was originally proposed by the Highway Research Board's Committee on classification of materials for subgrades and unpaved roads. According to this system, soils are divided into eight major groups, A-1 through A-8. The grouping is based on grain-size distribution, liquid limit, and plasticity indices. Soils listed in group A-1, A-2, and A-3 are coarse-grained materials, and those in group A-4, A-5, A-6, and A-7 are fine-grained materials. Peat, muck, and other highly organic soils are classified under A-8. Table 6 provides a list of group A-1 through A-7. 
Table 6. Classification of AASHTO subgrade materials (Das and Sobhan 2014).

\begin{tabular}{|c|c|c|c|c|c|c|c|c|c|c|c|}
\hline \multirow{3}{*}{$\begin{array}{l}\text { General classification } \\
\text { Group classification }\end{array}$} & \multicolumn{7}{|c|}{$\begin{array}{c}\text { Granular materials } \\
\text { (35\% or less of total sample } \\
\text { passing No. } 200)\end{array}$} & \multicolumn{4}{|c|}{$\begin{array}{c}\text { Silt-clay materials (more } \\
\text { than } 35 \% \text { of total sample } \\
\text { passing No. 200) }\end{array}$} \\
\hline & \multicolumn{2}{|l|}{$A-1$} & \multirow[t]{2}{*}{ A-3 } & \multicolumn{4}{|l|}{ A-2 } & \multirow[t]{2}{*}{ A-4 } & \multirow[t]{2}{*}{$A-5$} & \multirow[t]{2}{*}{ A-6 } & \multirow{2}{*}{$\begin{array}{l}A-7 \\
A-7-5^{a} \\
A-7-6^{b}\end{array}$} \\
\hline & A-1-a & A-1-b & & \begin{tabular}{|l|} 
A-2- \\
4
\end{tabular} & $\begin{array}{l}\text { A-2- } \\
5\end{array}$ & $\begin{array}{l}\text { A-2- } \\
6\end{array}$ & $\begin{array}{l}\text { A-2- } \\
7\end{array}$ & & & & \\
\hline \multicolumn{12}{|l|}{$\begin{array}{l}\text { Sieve analysis } \\
\text { (percentage passing) }\end{array}$} \\
\hline No. 10 & $\leq 50$ & - & - & - & - & - & - & - & - & - & - \\
\hline No. 40 & $\leq 30$ & $\leq 50$ & $\geq 51$ & - & - & - & - & - & - & - & - \\
\hline No. 200 & $\leq 15$ & $\leq 25$ & $\leq 10$ & $\leq 35$ & $\leq 35$ & $\leq 35$ & $\leq 35$ & $\geq 36$ & $\geq 36$ & $\geq 36$ & $\geq 36$ \\
\hline \multicolumn{12}{|l|}{$\begin{array}{l}\text { Characteristics of } \\
\text { fraction passing No. } 40\end{array}$} \\
\hline Liquid Limit & \multicolumn{2}{|l|}{-} & - & $\leq 40$ & $\geq 41$ & $\leq 40$ & $\geq 41$ & $\leq 40$ & $\geq 41$ & $\leq 40$ & $\geq 41$ \\
\hline Plasticity index & \multicolumn{2}{|l|}{$\leq 6$} & NP & $\leq 10$ & $\leq 10$ & $\geq 11$ & $\geq 11$ & $\leq 10$ & $\leq 10$ & $\geq 11$ & $\geq 11$ \\
\hline $\begin{array}{l}\text { Usual types of } \\
\text { significant constituent } \\
\text { materials }\end{array}$ & \multicolumn{2}{|c|}{$\begin{array}{l}\text { Strong } \\
\text { fragments, } \\
\text { gravel, and } \\
\text { sand }\end{array}$} & $\begin{array}{l}\text { Fine } \\
\text { sand }\end{array}$ & \multicolumn{4}{|c|}{$\begin{array}{l}\text { Silty or clayey gravel and } \\
\text { sand }\end{array}$} & \multicolumn{2}{|c|}{ Silty soils } & \multicolumn{2}{|c|}{ Clayey soils } \\
\hline General subgrade rating & \multicolumn{7}{|c|}{ Excellent to good } & \multicolumn{4}{|c|}{ Fair to poor } \\
\hline
\end{tabular}

\subsubsection{AASHTO unique soil terms}

The AASHTO classification system (USDA Module 2 1987) has its unique terms as listed below:

- Gravel - Soil particles that are finer than a 3 inch sieve and are retained on a No. 10 sieve (Table 5). This differs from the No. 4 sieve used by the USCS.

- Sand - Soil particles that are finer than a No. 10 sieve and retained on a No. 200 sieve. This differs from the No. 4 sieve used by the USCS.

- Coarse sand - A subdivision of sand. The soil particles finer than a No. 10 sieve and retained on a No. 40 sieve.

- Fine sand - A subdivision of sand. The soil particles finer than a No.40 sieve and retained on a No. 200 sieve.

- Fines - Soil particles finer than a No. 200 sieve. Expressed in percent of the dry weight of the soil passing a 3 inch sieve.

- Silty - Refers to soils that have a PI of 10 or less. 
- Clayey - Refers to soils that have a PI more than 10.

- Subgrade - The natural material at a particular location upon which a road or airfield is constructed.

- Base and or Sub-base - Materials placed on the subgrade generally as higher quality material than the material subgrade itself, as a supporting medium for improved roads and streets.

- Granular - Materials that have 35 percent or less finer than the No. 200 sieve. Percentages are on a dry weight basis.

- Silt-clay - Materials that have more than 35 percent finer than a No. 200 sieve on a dry weight basis.

- Group Index - A parameter that gives an indication of the load carrying capacity within an AASHTO soil group. It is numerically equal to Equation 2.

$$
G I=(F-35)[0.2+0.005(L L-40)]+0.01(F-15)(P I-15)(P I-10)(2)
$$

where:

$$
\begin{aligned}
F & =\text { Fines } \\
L L & =\text { Liquid Limit } \\
P I & =\text { Plasticity Index. }
\end{aligned}
$$

The group index (GI) is reported to the nearest whole number. It is listed in parentheses following the group symbol. A GI of (o) indicates the best construction material for base, sub-base, or subgrade. A GI of more than (20) indicates a very poor material for sub-base or subgrade. If the GI is calculated negative, it is reported (o).

The partial GI (PGI) is a parameter that may be calculated instead of GI for subgroup A-2-6 and A-2-7. Positive PGI values are reported to the nearest whole number. A negative PGI value is reported as (0).

The equation for PGI is the plasticity portion of the GI equation, or

$$
P G I=0.01(F-15)(P I-10)
$$

\subsubsection{Comparison of AASHTO and USCS classification systems}

There are significant differences between the AASHTO system and the USCS system. A unique comparison of the soil classifications according to 
both systems is not possible. A global comparison, however, is given in A Review of Engineering Soil Classification Systems by Liu (1967). Liu (1967) compared the AASHTO, USCS, and Food and Agriculture Organization of the United Nations (FAO) soil classification systems to identify whether or not these systems properly classify the soils with particular reference to transportation engineering. Table 8 and Table 9 summarize findings from Liu (1967), which are also discussed by Das and Sobhan (2014). Table 7 shows the mapping from AASHTO to USCS while Table 8 presents the reverse.

Table 7. Comparison of the AASHTO system with the USCS (Das and Sobhan 2014).

\begin{tabular}{|c|c|c|c|}
\hline \multirow{2}{*}{$\begin{array}{c}\text { Soil Group In AASHTO } \\
\text { System }\end{array}$} & \multicolumn{3}{|c|}{ Comparable Soil Group In USCS System } \\
\hline & Most Probable & Possible & Possible But Improbable \\
\hline A-1-a & GW, GP & SW, SP & GM, SM \\
\hline$A-1-b$ & SW, SP, GM, SM & GP & -- \\
\hline A-3 & SP & -- & SW, GP \\
\hline A-2-4 & GM, SM & $\mathrm{GC}, \mathrm{SC}$ & GW, GP, SW, SP \\
\hline$A-2-5$ & GM, SM & -- & GW, GP, SW, SP \\
\hline A-2-6 & $\mathrm{GC}, \mathrm{SC}$ & GM, SM & GW, GP, SW, SP \\
\hline A-2-7 & SM, SC, GM, GC & - & GW, GP, SW, SP \\
\hline A-4 & $\mathrm{ML}, \mathrm{OL}$ & $\mathrm{CL}, \mathrm{SM}, \mathrm{SC}$ & GM, GC \\
\hline$A-5$ & $\mathrm{OH}, \mathrm{MH}, \mathrm{ML}, \mathrm{OL}$ & -- & SM, GM \\
\hline A-6 & $\mathrm{CL}$ & $\mathrm{ML}, \mathrm{OL}, \mathrm{SC}$ & GC, GM, SM \\
\hline$A-7-5$ & $\mathrm{OH}, \mathrm{MH}$ & $\mathrm{ML}, \mathrm{OL}, \mathrm{CH}$ & GM, SM, GC, SC \\
\hline A-7-6 & $\mathrm{CM}, \mathrm{CL}$ & $\mathrm{ML}, \mathrm{OL}, \mathrm{SC}$ & $\mathrm{OH}, \mathrm{MH}, \mathrm{GC}, \mathrm{GM}, \mathrm{SM}$ \\
\hline
\end{tabular}

Table 8. Comparison of the USCS with the AASHTO system (Das and Sobhan 2014).

\begin{tabular}{|c|c|c|l|}
\hline \multirow{2}{*}{$\begin{array}{c}\text { Soil Group In } \\
\text { USCS }\end{array}$} & \multicolumn{2}{|c|}{ Comparable Soil Group In AASHTO System } \\
\cline { 2 - 4 } & Most Probable & Possible & Possible But Improbable \\
\hline GW & A-1-a & - & A-2-4, A-2-5, A-2,6, A-2-7 \\
\hline GP & A-1-a & A-1-b & A-3, A-2-4, A-2-5, A-2-6, A-2-7 \\
\hline GM & A-1-b, A-2-4, A-2-5, A-2-7 & A-2-6 & A-4, A-5, A-6, A-7-5, A-7-6, A-1-a \\
\hline GC & A-2-6, A-2-7 & A-2-4 & A-4, A-6, A-7-6, A-7-5 \\
\hline SW & A-1-b & A-1-a & A-3, A-2-4, A-2-5, A-2-6, A-2-7 \\
\hline SP & A-3, A-1-b & A-1-a & A-2-4, A-2-5, A-2-6, A-2-7 \\
\hline
\end{tabular}




\begin{tabular}{|c|c|c|l|}
\hline \multirow{2}{*}{$\begin{array}{c}\text { Soil Group In } \\
\text { USCS }\end{array}$} & \multicolumn{3}{|c|}{ Comparable Soil Group In AASHTO System } \\
\cline { 2 - 4 } & Most Probable & Possible & \multicolumn{1}{|c|}{ Possible But Improbable } \\
\hline SM & A-1-b, A-2-4, A-2-5, A-2-7 & A-2-6, A-4 & A-5, A-6, A-7-5, A-7-6, A-1-a \\
\hline SC & A-2-6, A-2-7 & A-2-4, A-6, A-4, A-7-6 & A-7-5 \\
\hline ML & A-4, A-5 & A-6, A-7-5, A-7-6 & - \\
\hline CL & A-6, A-7-6 & A-4 & - \\
\hline OL & A-4, A-5 & A-6, A-7-5, A-7-6 & - \\
\hline MH & A-7-5, A-5 & -- & A-7-6 \\
\hline CH & A-7-6 & A-7-5 & - \\
\hline OH & A-7-5, A-5 & - & A-7-6 \\
\hline Pt & A-8 & - & -- \\
\hline
\end{tabular}

\subsection{U.S. Department of Agriculture (USDA) textural soil classification}

The USDA textural soil classification is based on the particle size distribution. This type of soil classification has been introduced and developed mainly by the USDA. This textural classification system divides soils based upon grain size and texture into 12 primary soil types. The USDA triangle chart below (Figure 3) (USDA 1987) is divided into percentage of sand, percentage of clay, and percentage of silt. Solid lines show the divisions between 12 basic soil texture classes (S, LS, SL, SIL, SI, L, SCL, CL, SICL, SC, SIC, and C). The summation of the three percentages of sand, silt and clay must be 100 percent. The particle size fractions defined according to USDA (1987) are sand (2-0.5 mm), silt (0.050$0.002 \mathrm{~mm}$ ) and clay (>0.002 mm). 
Figure 3. USDA textural triangle for particle size distribution classes used in original data of Tier 3 Data (USDA 1987).

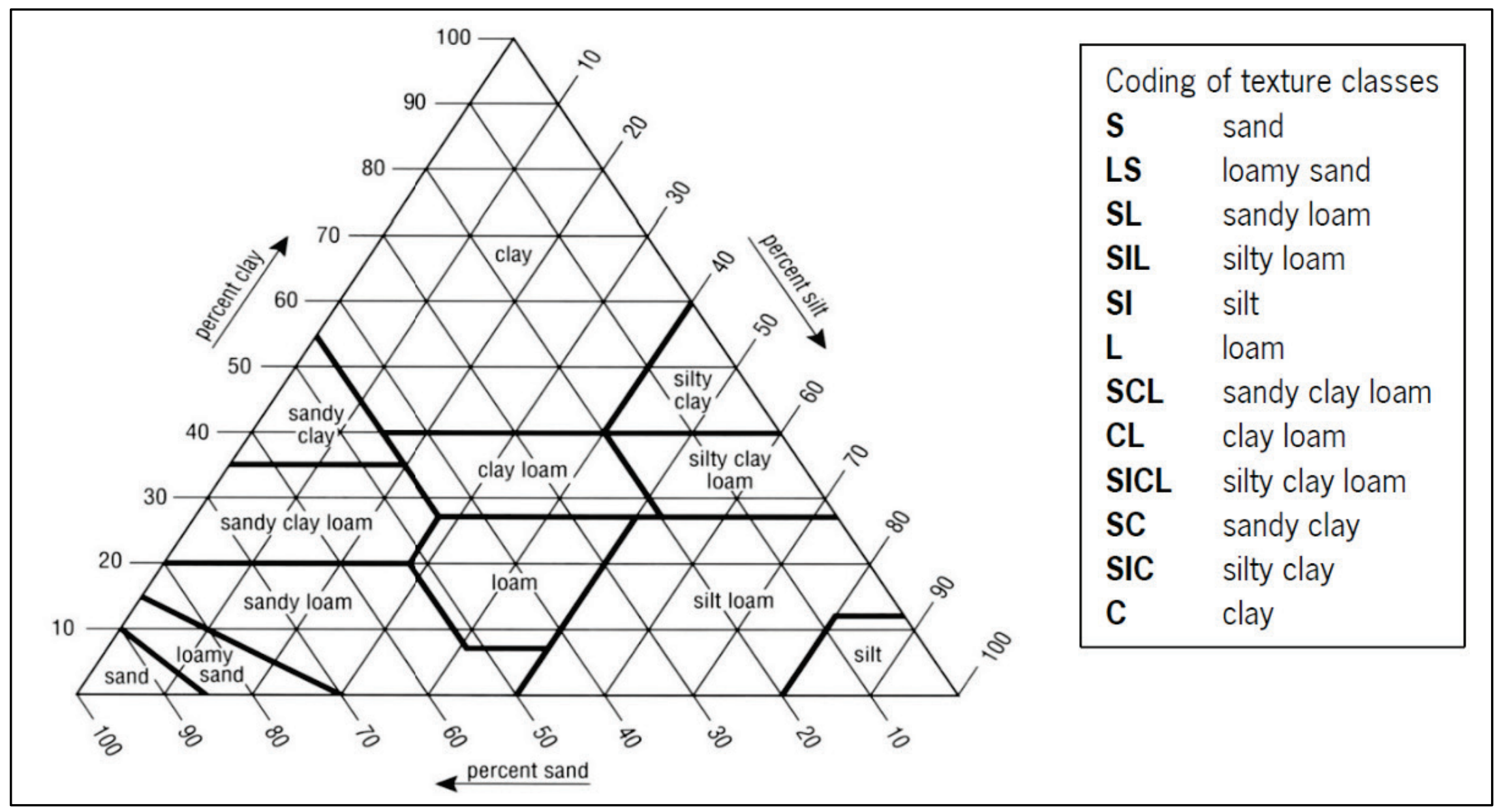




\subsubsection{Properties of USDA textural classes}

The important properties that can be used to differentiate soil's behavior in the USDA textual classification system are defined below:

- Specific Surface - Specific surface is the surface area of a soil particle per unit of mass. For instance, sands are the largest soil separate but have a relative high unit mass. Therefore, they have small specific surfaces. Clays include very small particles, have extremely low mass and large specific surfaces. Small, intermediate, and large are the terms used to describe a soil particle's specific surface (Table 8).

- Plasticity - Plasticity is the property of a soil that enables it to change shape continuously under the influence of an applied stress and to retain that shape on removal of the stress. This definition differs from that used by engineers in USCS soil classification. The descriptive terms used to describe plasticity are non-plastic (NP), slightly plastic, plastic, and very plastic. Plasticity depends on the amount and type of clay present and the water content.

- Stickiness - Stickiness is the adhesion exhibited by a soil and water mixture to other objects. It depends on the amount and type of clay and the water content. Descriptive terms used are non-sticky, slightly sticky, sticky, and very sticky.

- Particle Composition - Composition is the material that constitutes a soil's makeup. It may be parent rock material such as limestone, a primary mineral such as quartz, or a clay mineral such as Montmorillonite.

- Visibility - Visibility is the ease with which an observer can actually see the individual particles of a soil.

- Shape - Shape is the form of the individual soil particle. The normal particle shapes are round, irregular, or flat.

- Water Absorption and Retention - Water absorption and retention is the capability of a soil to readily take on and retain water. These properties are generally dependent on the amount and type of clay present in the soil. Terms used to describe these properties are low, moderate, and high.

Table 9 provides the above properties for sand, silt, and clay minerals. 
Table 9. A comparison of the reactions of three soil separates to certain behavioral properties based on USDA particle size class (USDA 1987).

\begin{tabular}{|c|c|c|c|}
\hline \multirow[b]{2}{*}{ Property } & \multicolumn{3}{|c|}{ Soil Separate } \\
\hline & Sand & Silt & Clay \\
\hline Specific surface & Small & Intermediate & Large \\
\hline Plasticity & Nonplastic & Nonplastic to slightly plastic & $\begin{array}{l}\text { Plastic to very } \\
\text { plastic }\end{array}$ \\
\hline Stickiness & Nonsticky & Nonsticky to slightly sticky & $\begin{array}{l}\text { Sticky to very } \\
\text { sticky }\end{array}$ \\
\hline Particle Composition Minerals & $\begin{array}{l}\text { Rock } \\
\text { fragments }\end{array}$ & Primary materials & Clay minerals \\
\hline Visibility of individual particles & Eye & $\begin{array}{l}\text { Large ones can be seen with a } \\
\text { hand lens }\end{array}$ & $\begin{array}{l}\text { Electron } \\
\text { microscope }\end{array}$ \\
\hline Shape & Round & Irregular & Flat \\
\hline $\begin{array}{l}\text { Ability to absorb and retain } \\
\text { water }\end{array}$ & Low & Low to moderate & High \\
\hline Size & $2.0-0.5 \mathrm{~mm}$ & $0.05-0.002 \mathrm{~mm}$ & $\begin{array}{l}\text { Less than } 0.002 \\
\mathrm{~mm}\end{array}$ \\
\hline
\end{tabular}

\subsubsection{Size and percentage criteria for the 12 major USDA textural classes}

The 12 major soil USDA textural classes, shown in Figure 3, are based on the relative percentage of sand, silt, and clay in the soil sample or material (USDA 1987). The definitive criteria for each of these classes are defined in Table 10. In the database, Tier 3 original soil data, these class symbols are used for data provided by the Soil and Terrain database for Latin America and the Caribbean (SOTER) database (van Engelen and Dijkshoorm 2013). The soil classification groups provided in Table 10 also are called particle size class and described in detail in the U.S. Department of Agriculture, Soil Mechanics Level I. Module 3-USDA Textual Soil Classification, Study Guide (USDA 1987). 
Table 10. Criteria for 12 major USDA textural classes (USDA 1987).

\begin{tabular}{|c|c|c|}
\hline $\begin{array}{l}\text { USDA } \\
\text { Textural Class }\end{array}$ & $\begin{array}{l}\text { Soil Class } \\
\text { Name }\end{array}$ & Description \\
\hline S & Sand & $\begin{array}{l}\text { Must contain } 85 \text { percent or more of sand, and } \\
\text { The percentage of silt plus } 1.5 \text { times the percentage of clay does not } \\
\text { exceed } 15 .\end{array}$ \\
\hline LS & Loamy Sand & $\begin{array}{l}\text { Upper Limit: } \\
\text { Must contain } 85 \text { to } 90 \text { percent of sand, and } \\
\text { The percentage of silt plus } 1.5 \text { times the percentage of clay is not less than } \\
15 . \\
\text { Lower Limit: } \\
\text { Must contain } 70 \text { to } 85 \text { percent of sand, and } \\
\text { The percentage of silt plus twice the percentage of clay does not exceed } 30 \text {. }\end{array}$ \\
\hline SL & Sandy Loam & $\begin{array}{l}\text { Contains } 20 \text { percent or less clay, and } \\
\text { The percentage of silt plus twice the percentage of clay exceeds } 30 \text { and has } \\
52 \text { percent or more sand, or } \\
\text { Contains less than } 7 \text { percent clay, less than } 50 \text { percent silt, and between } \\
43 \text { and } 52 \text { percent sand. }\end{array}$ \\
\hline L & Loam & $\begin{array}{l}\text { Contains } 7 \text { to } 27 \text { percent clay, } 28 \text { to } 50 \text { percent silt, and less than } 52 \\
\text { percent sand. }\end{array}$ \\
\hline SIL & Silty Loam & $\begin{array}{l}\text { Contains } 50 \text { percent or more silt and } 12 \text { to } 27 \text { percent clay, or } \\
\text { Contains } 50 \text { to } 80 \text { percent silt and less than } 12 \text { percent clay. }\end{array}$ \\
\hline SI & Silt & Contains 80 percent or more silt and less than 12 percent clay. \\
\hline $\mathrm{SCL}$ & $\begin{array}{l}\text { Sandy Clay } \\
\text { Loam }\end{array}$ & $\begin{array}{l}\text { Contains } 20 \text { to } 35 \text { percent cl ay, less than } 28 \text { percent silt, and } 45 \text { percent } \\
\text { or more sand. }\end{array}$ \\
\hline $\mathrm{CL}$ & Clay Loam & Contains 27 to 40 percent clay and 20 to 45 percent sand. \\
\hline SICL & Silty Clay Loam & $\begin{array}{l}\text { Contains } 27 \text { to } 40 \text { percent or more clay and less than } 20 \text { percent or more } \\
\text { sand. }\end{array}$ \\
\hline SC & Sandy Clay & Contains 35 percent or more $\mathrm{cl}$ ay and 45 percent or more sand. \\
\hline $\mathrm{SIC}$ & Silty Clay & Contains 40 percent or more $\mathrm{cl}$ ay and 40 percent or more silt. \\
\hline $\mathrm{C}$ & Clay & $\begin{array}{l}\text { Contains } 40 \text { percent or more clay, less than } 45 \text { percent sand, and less than } \\
40 \text { percent silt. }\end{array}$ \\
\hline
\end{tabular}

\subsection{Correlation between USDA and USCS classification}

For many locations around the world, access to soil textural (particle size distribution) data from agricultural sources is available; however, USCS data remains unavailable. There is no absolute translation from the USDA textural system to an equivalent USCS classification. However, many methods have been proposed to do this. In the past, several researchers studied the correlation between the soil texture classifications (here, it is referred to as USDA classification) to USCS classification. 


\subsubsection{USDA and USCS correlation by Curtis (2005)}

Curtis (2005) studied whether or not USDA and USCS classifications are comparable. Most of the data were collected from 1990 to 2001, mainly from military installations in the United States, Europe, and the Middle East. Some of the samples were prepared by ERDC researchers while others were obtained from the National Soils Survey Center in Lincoln, NE (Curtis 2005). Of the 1080 samples in Curtis's (2005) study, between 300 and 400 were classified in both USCS and the USDA system. Curtis (2005) mapped the USCS classed soils onto the USDA triangle, which is presented in Figure 4. Normally, one can conclude that there is no simple way to transfer USDA classifications to the USCS and vice versa.

Figure 4. USCS classification mapped onto the USDA triangle by Curtis (2005).

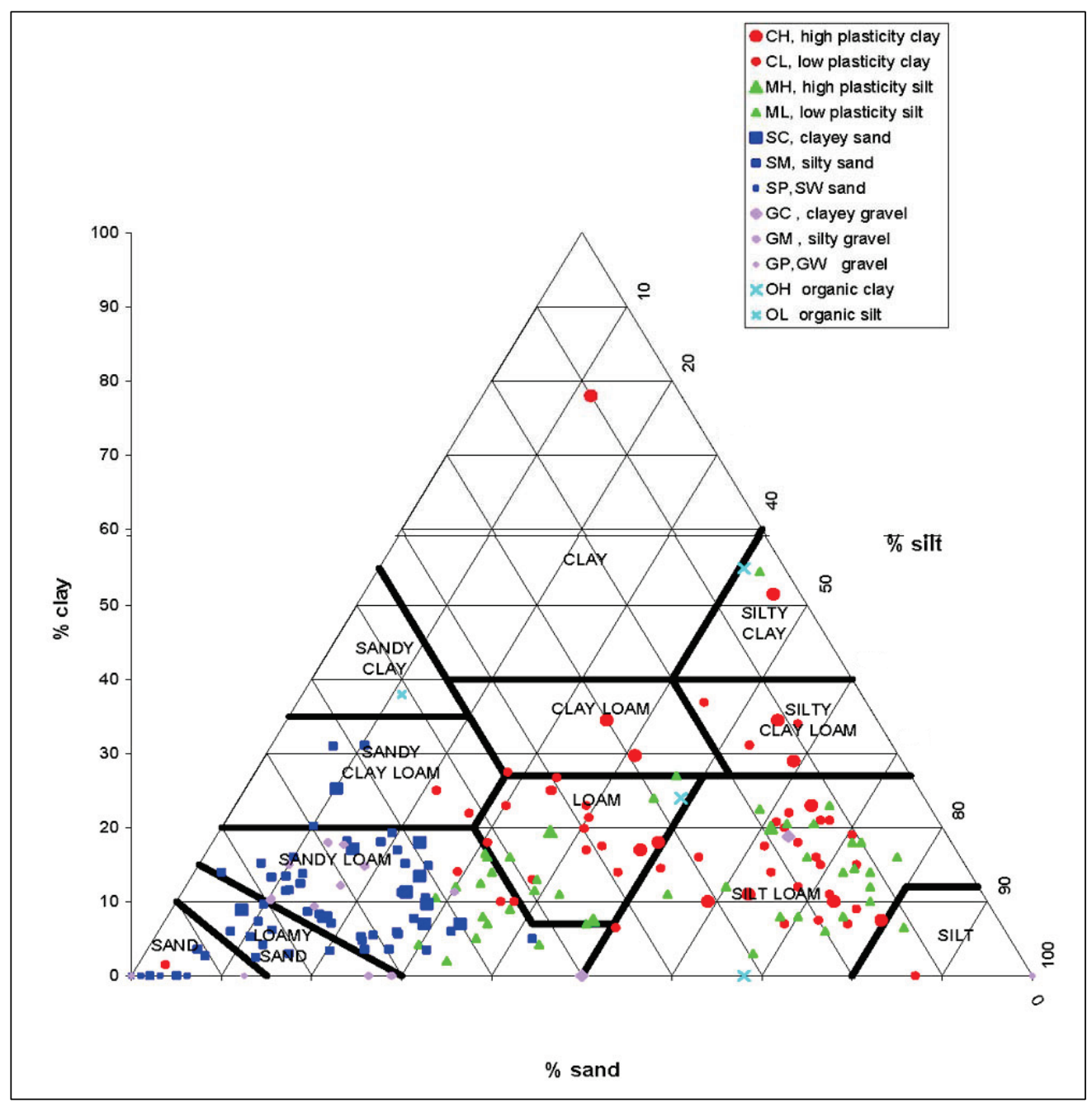




\subsubsection{USDA and USCS correlation by Ayers (2011)}

Ayers et al. (2011) presented a USCS version of the USDA triangle as shown in Figure 5. Using Ayers et al. (2011) data and an area-weighted mean, Garcia-Gaines and Frankenstein (2015) estimated the top two USCS classifications for each USDA type. In some cases, such as with clay, there was only one mapping. If two USCS classifications have approximately equal area means under the same USDA classification, both USCS classifications are considered as the most probable value. For example, clay loam can be classified as either MH or CL with equal probability by area mean. Table 11 lists Garcia-Gaines and Frankenstein (2015) mapping results.

Figure 5. USCS classification mapped onto the USDA triangle by Ayers et al. (2011).

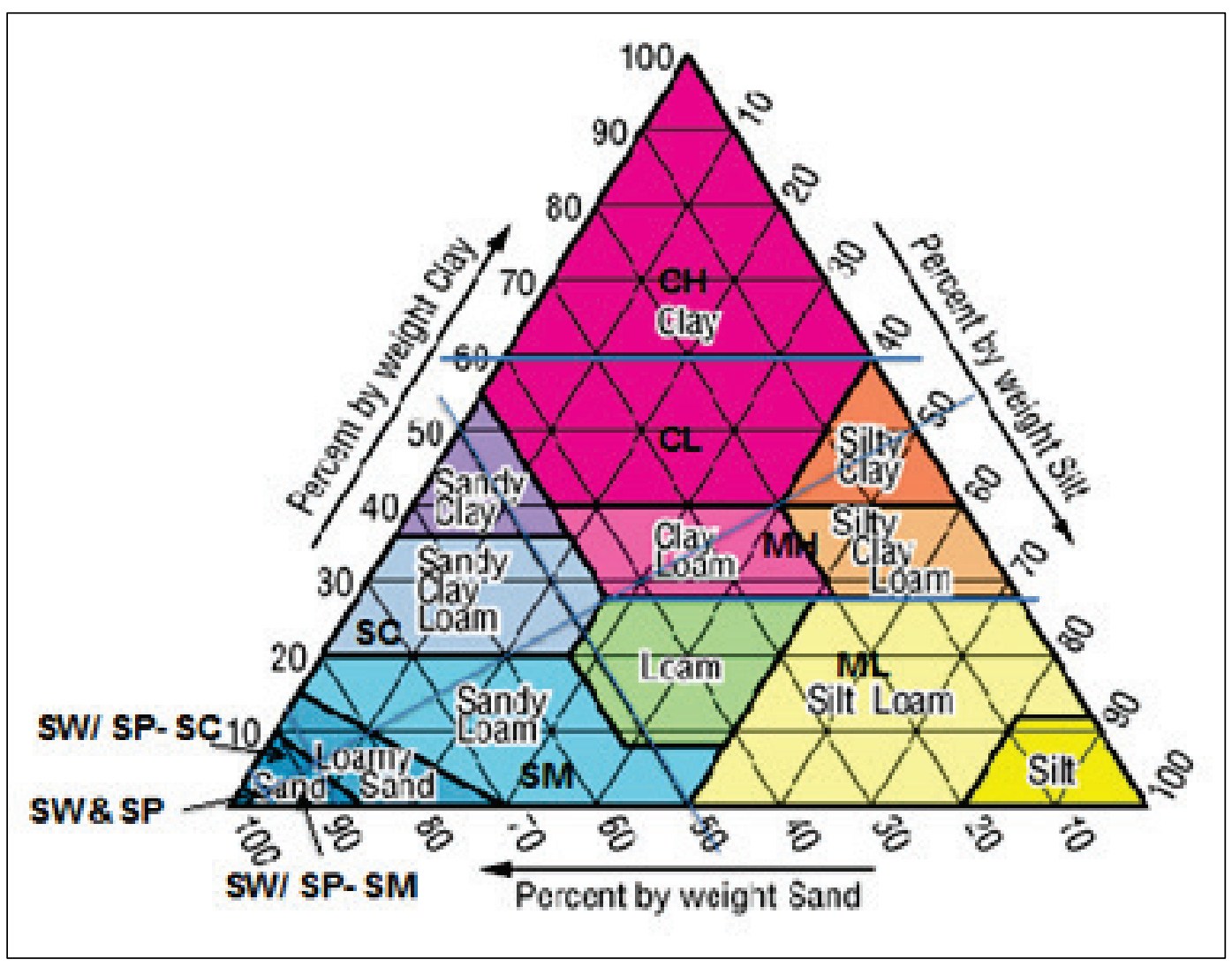


Table 11. USCS fit for USDA based on Ayers et al. (2011) data (Garcia-Gaines and Frankenstein 2015).

\begin{tabular}{|l|c|c|}
\hline \multirow{2}{*}{ USDA Classification } & \multicolumn{2}{|c|}{ USCS Classification } \\
\cline { 2 - 3 } & $\begin{array}{c}\text { Most } \\
\text { Probable }\end{array}$ & Possible \\
\hline Sand & SW, SP & -- \\
\hline Loamy Sand & SM & SC \\
\hline Sandy Loam & SM & -- \\
\hline Sandy Clay Loam & SC & -- \\
\hline Sandy Clay & SC & CL \\
\hline Loam & $\mathrm{ML}$ & -- \\
\hline Silt Loam & $\mathrm{ML}$ & - \\
\hline Silt & $\mathrm{ML}$ & -- \\
\hline Clay Loam & $\mathrm{CL}, \mathrm{MH}$ & -- \\
\hline Silty Clay Loam & $\mathrm{MH}$ & -- \\
\hline Clay & $\mathrm{CH}$ & $\mathrm{CL}$ \\
\hline Silty Clay & $\mathrm{CL}, \mathrm{MH}$ & -- \\
\hline Peat & -- & - \\
\hline
\end{tabular}

\subsubsection{USDA and USCS correlation by Baylot et al. (2013)}

Baylot et al. (2013) conducted a study to predict ground vehicle crosscountry mobility for combatant commands using the North Atlantic Treaty Organization (NATO) Reference Mobility Model (NRMM). Soil data from the Air Force Weather Agency (AFWA), based on data from the FAO, were used to estimate soil moisture. The FAO classifies its data using the USDA system. To estimate soil strength, NRMM needs USCS soil classifications. Table 12 lists Baylot et al. (2013) mapping algorithm for converting from USDA to USCS classifications.

Table 12. Soil classification group conversion (Baylot et al. 2013).

\begin{tabular}{|c|l|l|}
\hline FAO Number & USDA Classification & USCS Classification \\
\hline 1 & Sand & SP, poorly sorted sand \\
\hline 2 & Loamy Sand & SM, silty sand \\
\hline 3 & Sandy Loam & SC, clayey sand \\
\hline 4 & Silty Loam & SM, silty sand \\
\hline 5 & Silt & ML, low-plasticity silt \\
\hline
\end{tabular}




\begin{tabular}{|c|l|l|}
\hline FAO Number & USDA Classification & USCS Classification \\
\hline 6 & Loam & CL, low-plasticity clay \\
\hline 7 & Sandy Clay Loam & SC, clayey sand \\
\hline 8 & Silty Clay Loam & CL, low-plasticity clay \\
\hline 9 & Clay Loam & CL, low-plasticity clay \\
\hline 10 & Sandy Clay & SC, clayey sand \\
\hline 11 & Silty Clay & CL, low-plasticity clay \\
\hline 12 & Clay & CH, high plasticity clay \\
\hline 13 & Organic & OH, high plasticity organic soil \\
\hline
\end{tabular}

\subsubsection{USDA and USCS correlation by Frankenstein (2014)}

Frankenstein and Koenig (2004) developed a one-dimensional dynamic model called Fast All-Season Soil Strength (FASST). FASST's fundamental operations are the calculation of an energy and water budget that quantifies both the flow of heat and moisture within the soil and also the exchange of heat and moisture at all interfaces (ground/air or ground/snow; snow/air) using both meteorological and terrain data.

FASST can use the USDA classification system but was originally written to utilize the USCS method (Frankenstein and Koenig 2004). Because there is not a direct relationship between both classification systems, substantial overlap can occur. As stated before, a large amount of soils data has only USDA classification; and currently, FASST uses its own conversion scheme to relate soils data from one system to another as shown in Table 13 (Frankenstein 2014).

Table 13. USDA classification equivalency in USCS classification (Frankenstein 2014).

\begin{tabular}{|l|c|}
\hline USDA Classification & USCS Classification \\
\hline Sand & SP \\
\hline Loamy Sand & SM \\
\hline Sandy Loam & SM \\
\hline Sandy Clay Loam & SC \\
\hline Sandy Clay & SC \\
\hline Loam & $\mathrm{ML}$ \\
\hline Silty Loam & $\mathrm{ML}$ \\
\hline
\end{tabular}




\begin{tabular}{|l|c|}
\hline USDA Classification & USCS Classification \\
\hline Silt & $\mathrm{ML}$ \\
\hline Clay Loam & $\mathrm{CL}$ \\
\hline Silty Clay Loam & $\mathrm{CL}$ \\
\hline Clay & $\mathrm{CH}$ \\
\hline Silty Clay & $\mathrm{CH}$ \\
\hline Peat & $\mathrm{Pt}$ \\
\hline
\end{tabular}

\subsection{Tingle et al. (2016) soil matrix}

The USCS is the current soil classification system used by the ERDC and DoD (Tingle et al. 2016). Internationally, the British Soil Classification (BSCS) is based on particle size and is another modification of the Airfield Classification System (ACS). The USCS is a modified version of ACS. Germany uses the DIN 18196 soil classification system (Hack et al. 2004), which is similar to USCS. However, the French Soil Classification System focuses on the processes occurring in the soil, such as the source of deposition, agricultural characteristics, and drainage behavior. Most recently, many European countries have adopted the use of the European Standard EN ISO 14688-2 (Kovacevic et al. 2016), which differs considerably from USCS in terms of the grain sizes used to differentiate between soil classes and the characterization of the plastic behavior. Many other countries in South America, Africa, and Asia employ current U.S. or European (e.g., USCS) classification systems intact or with slight modification, based on the historical presence of the United States and European countries. Recognizing the need to integrate many diverse classification systems, the ERDC (Tingle et al. 2016) has developed a correlation soil (matrix) table to relate soils information from the above different international soil classification systems (Table 14).

Each of these soil classification systems seeks to group soils based upon their typical particle sizes and their behavioral characteristics. While similar in purpose, and in some cases, methodology, the soil groupings differ between systems and difficult to relate to one another. 
Table 14. USCS and other soil classification systems (Tingle et al. 2016).

\begin{tabular}{|c|c|c|c|c|c|c|c|c|c|c|c|c|c|c|c|}
\hline \multirow{2}{*}{$\operatorname{uscs} x$} & \multirow{2}{*}{$\begin{array}{c}\text { British Soil } \\
\text { Classification System } \\
\text { [BSCS] }\end{array}$} & \multirow{2}{*}{\begin{tabular}{|l|} 
German \\
DIN 18196
\end{tabular}} & \multirow{2}{*}{$\begin{array}{c}\text { ESCS }^{\pi \pi} \\
\text { EN ISO 14688- } \\
2\end{array}$} & \multirow{2}{*}{ France } & \multirow{2}{*}{ AASHTD } & \multirow{2}{*}{ Proposed Grouping } & \multicolumn{2}{|c|}{ Typical Design Values } & \multirow{2}{*}{$\begin{array}{c}\begin{array}{c}\text { Typical } \\
\text { Compacted } \\
\text { Dry Density }\end{array} \\
\\
\mathrm{Mg}^{3} \mathrm{~m}^{3}\end{array}$} & \multirow{2}{*}{$\begin{array}{c}\text { Typical } \\
\text { OMC } \\
\text { Range. } \\
\%\end{array}$} & \multicolumn{5}{|c|}{ General Soil Suitability } \\
\hline & & & & & & & CBR, \% & $\begin{array}{l}\text { 'k' Value } \\
\text { [pci] }\end{array}$ & & & $\begin{array}{l}\text { Foundation } \\
\text { Value } \\
\text { Non-Frost }\end{array}$ & $\begin{array}{c}\text { Road } \\
\text { Base Coarse }\end{array}$ & $\begin{array}{c}\text { Potential } \\
\text { Frost } \\
\text { Action }\end{array}$ & $\begin{array}{c}\text { Shrink- } \\
\text { Swell } \\
\text { Potential }\end{array}$ & \begin{tabular}{|l} 
Drainage \\
Characteristics
\end{tabular} \\
\hline GW & $\mathrm{GW}$ & GW & GrW & D1, D2 & A-1-a & \multirow{4}{*}{ I. GC-GW (Gravel) } & $60-100$ & $300-750$ & \multirow{4}{*}{$1.7-2.3$} & \multirow{4}{*}{ 3-11 } & \multirow{4}{*}{$\begin{array}{l}\text { Good to } \\
\text { Excellent }\end{array}$} & \multirow{4}{*}{ Poor to Good } & \multirow{4}{*}{$\begin{array}{c}\text { Medium to } \\
\text { Almost } \\
\text { None }\end{array}$} & \multirow{4}{*}{\begin{tabular}{|c|} 
Slight to \\
Almost None
\end{tabular}} & \multirow{4}{*}{$\begin{array}{l}\text { Practically } \\
\text { Impervious to } \\
\text { Excellent }\end{array}$} \\
\hline GP & GP, GPg & $\mathrm{GE}, \mathrm{GI}$ & GrP, GrM & D1, D2 & A-1-a & & \begin{tabular}{|l|}
$35-60$ \\
\end{tabular} & $300-500$ & & & & & & & \\
\hline GM & $\begin{array}{l}\text { GML, GMI, GMH, GMV, } \\
\text { GME }\end{array}$ & GU & \begin{tabular}{|c|} 
siGrW, siGrP, \\
siGrM
\end{tabular} & $\mathrm{c} 1, \mathrm{c} 2, \mathrm{c} 3, \mathrm{~B} 5$ & $\begin{array}{c}\text { A-1-B, A-2-4, A-2 } \\
5, A-2-7\end{array}$ & & $35-60$ & $300-500$ & & & & & & & \\
\hline GC & GCL, GCI, GCH, GCV, GCE & GT & $\begin{array}{c}\text { clGrW, c|GrP, } \\
\text { clGrM }\end{array}$ & $\mathrm{c} 1, \mathrm{c} 2, \mathrm{c3}, \mathrm{B} 6$ & $A-2-6, A-2-7$ & & $20-40$ & 200-300 & & & & & & & \\
\hline sw & GW, sw & GE, GI, SW & SaW & $\begin{array}{l}\text { D1, D2, B1, } \\
\text { B2, B3, B4 }\end{array}$ & $a-1-B$ & \multirow{5}{*}{ II. ML-SW (Silt-Sand) } & $20-60$ & $200-500$ & \multirow{5}{*}{$1.50-2.0$} & \multirow{5}{*}{$5.8-20$} & \multirow{5}{*}{ Fair to Good } & \multirow{5}{*}{$\begin{array}{c}\text { Not Suitable to } \\
\text { Poor }\end{array}$} & \multirow{5}{*}{$\begin{array}{c}\text { Medium to } \\
\text { Almost } \\
\text { None }\end{array}$} & \multirow{5}{*}{$\begin{array}{l}\text { Medium to } \\
\text { High to } \\
\text { Almost None }\end{array}$} & \multirow{5}{*}{$\begin{array}{l}\text { Practically } \\
\text { Impervious to } \\
\text { Excellent }\end{array}$} \\
\hline SP & SP, SPg & SE, SI & SAM, SaP & $\begin{array}{l}\text { D1, D2, B1, } \\
\text { B2, B3, B4 }\end{array}$ & $A-3, A-1-b$ & & $10-25$ & $200-300$ & & & & & & & \\
\hline sM & $\begin{array}{l}\text { GML, GMI, GMH, GMV, } \\
\text { GME, SML, SMI, SMH, } \\
\text { SMV, SME }\end{array}$ & su* & $\begin{array}{c}\text { sisaW, sisap, } \\
\text { sisam }\end{array}$ & $\left|\begin{array}{c}\mathrm{B} 1, \mathrm{~B} 2, \mathrm{~B} 3, \mathrm{~B} 4 \\
\mathrm{~B} 5, \mathrm{~B} 6\end{array}\right|$ & $\begin{array}{c}A-1-B, A-2-4, A-2 \\
5, A-2-7\end{array}$ & & $20-40$ & $200-300$ & & & & & & & \\
\hline sc & $\begin{array}{l}\text { GCL, GCI, GCH, GCV, GCE, } \\
\text { SCL, SCl, SCH, SCV, SCE }\end{array}$ & ST & $\begin{array}{c}\text { clsaW, cISaP, } \\
\text { cISaM }\end{array}$ & $\begin{array}{c}\text { B1, B2, B3, B4, } \\
\text { B5, B6 }\end{array}$ & $A-2-6, A-2-7$ & & $10-20$ & $150-200$ & & & & & & & \\
\hline $\mathrm{ML}$ & $\mathrm{ML}, \mathrm{MI}$ & UL & SiL, Sil & A1 & $A-4, A-5$ & & $5-15$ & $100-200$ & & & & & & & \\
\hline $\mathrm{CL}$ & $\mathrm{ML}, \mathrm{CL}, \mathrm{CL}-\mathrm{ML}$ & TL, ST & CIL, ClI & A2 & $A-6, A-7-6$ & \multirow{2}{*}{ III. CH-CL (Clay) } & 5-15 & $100-200$ & \multirow{2}{*}{$1.40-1.70$} & \multirow{2}{*}{$12-30$} & \multirow{2}{*}{$\begin{array}{l}\text { Very Poor to } \\
\text { Poor }\end{array}$} & \multirow{2}{*}{ Not Suitable } & \multirow{2}{*}{$\begin{array}{l}\text { Medium to } \\
\text { Medium to } \\
\text { Very High }\end{array}$} & High to & Practically \\
\hline $\mathrm{CH}$ & $\mathrm{MV}, \mathrm{ME}, \mathrm{CH}, \mathrm{CV}, \mathrm{CE}$ & TM & $\mathrm{ClH}$ & $\mathrm{A} 3, \mathrm{~A} 4$ & $A-7-6$ & & $3-5$ & $50-100$ & & & & & & $\mid \begin{array}{c}\text { Medum to } \\
\text { High }\end{array}$ & $\begin{array}{c}\text { Impervious to } \\
\text { Poor }\end{array}$ \\
\hline $\mathrm{MH}$ & $\mathrm{MV}, \mathrm{ME}$ & UM & $\mathrm{SiH}$ & $\mathrm{A} 3, \mathrm{~A} 4$ & $A-7-5, A-5$ & IV. Pt-OH-MH & 3-5 & $50-100$ & & & & & & & \\
\hline PT & PT & $\mathrm{HN}, \mathrm{HZ}$ & Or & $\mathrm{F}$ & A-5 & (Organic and Over- & 1 & $10-25$ & $0.48-0.90$ & - & Not Suitable & Not Suitable & Slight & Very & Poor to Fair \\
\hline $\mathrm{OH}$ & PT & $\mathrm{HN}, \mathrm{HZ}$ & Or & $\mathrm{F}$ & $A-5$ & Consolidated Soils) & 3-5 & $50-100$ & & & & & & & \\
\hline & $\begin{array}{l}\text { Unified Soil Classication Sys } \\
\text { and the sands have the greal a } \\
\text { graded (W) soils have a gao } \\
\text { European Soi Classifiction } \\
\text { American Asssociation of Sta }\end{array}$ & $\begin{array}{l}\text { (USCS). The } \\
\text { ortion passing } \\
\text { resentation o } \\
\text { m (ESCS) es } \\
\text { ighway and } 7\end{array}$ & $\begin{array}{l}\text { Se-grainec } \\
\text { Nor } 4 \text { siev } \\
\text { aarticle siz } \\
\text { shed in } 20 \\
\text { sportation }\end{array}$ & $\begin{array}{l}\text { subdivided it } \\
\text { se gravel (G) a } \\
\text { as the poorly } \\
\text { dopted by } 34 \text { E } \\
\text { (AASSHTO) }\end{array}$ & $\begin{array}{l}\text { ravels and } g r \\
\text { he sand (S) } g \\
\text { ed (P) soils ar } \\
\text { pean Countrie }\end{array}$ & $\begin{array}{l}\text { soils [G] and sands } \\
\text { re divided into fou } \\
\text { runiform or skip-0. }\end{array}$ & $\begin{array}{l}\text { sandy } \\
\text { ndary } \\
\text { graded }\end{array}$ & $\begin{array}{l}\text { S). The } \\
\text { s. GW at }\end{array}$ & ar & & $\mathrm{ASC}$ & th & fistril & nd nature & $\begin{array}{l}\text { the No. } 4 \text { sieve, } \\
n \text { the soils. Well- }\end{array}$ \\
\hline
\end{tabular}




\section{Soil Data Sources}

As discussed earlier, several soil classification systems have been developed around the world to address various needs of soil data use. Each classification system describes particular soil properties (permeability, strength, color, etc.) and follows its own scheme (particle size distribution, morphology, etc.). There is no direct relationship between soil classification systems, and relating soil classification from one to another can be a difficult task. Because of its relative simplicity, most soil databases classify soils using a textural classification system (Das 2010). Due to the need to relate soil data to engineering properties, further analysis have been developed to convert textural classification systems to USCS or AASHTO soil classifications.

The USDA (1987) textural classification system is not commonly used in engineering because it fails to describe important soil properties (e.g., plasticity). For this reason, USCS soil classification system is preferred by engineers. Some mappings have been created between USCS and the USDA classification system, but discrepancies exist between them. The database described in this report includes a methodology for the numerical conversion between the USDA soil classification and USCS system. This conversion allows for soil data with only USDA classifications to be converted to equivalent USCS classification group. As a result, additional soil data will be available for engineering interests.

A crucial part of this project was to search, collect, evaluate available worldwide sources of soil data, databases, maps, and reports. An important goal for the database was to begin to integrate the DoD disparate soil databases. This started with reviewing the historical background of world soil data collections, classification systems, and software developments. The soil data sources were ranked by the world continents, countries, and regions. The world continents included North America, Central America, South America, South Africa, West Africa, East Africa, East Asia, West Asia, South Asia, South East Asia, Oceania (Australia), Northern Europe, Western Europe, Southern Europe, and Eastern Europe. Data were first collected from countries from Asia (e.g., China and South Korea), countries from South Africa (e.g., South Africa), 
South America countries, Middle Eastern countries, and finally data collected from the North American countries.

South American countries such as Brazil, Argentina, Colombia, Bolivia, Peru, Chile, Paraguay, Venezuela, Uruguay, Ecuador, Guyana, Suriname, and French Guiana were used as search terms in Google Searches for georeferenced soil classification data. Soil data parameters included percent of clay, percent of sand, and percent of silt, bulk density, surface organic carbon, and moisture content, with latitude and longitude or soil maps. Some databases were available in Microsoft Access format that could be incorporated into the database without any format modification. These include data for country such as Brazil (Cooper et al. 2005). Here, the data were very clearly labeled in terms of grain sizes. The most helpful link was D.G. Rossiter's Soil Geographic Databases website with Cornell University (http://isric.org/explore/soil-geographic-databases). This was also a good place to start for information beyond South America.

The next most helpful sources of data were the SOTER from the International Soil Reference and Information Centre (ISRIC). There is also a specific SOTERs data for Brazil and Argentina, Eastern European countries, Middle Eastern countries, African countries, and Eastern Asian countries. There are also SOTER-based soil parameter estimates for the same regions. These databases are in Microsoft Access formats and contain information about the type of soil.

Data were also collected from some miscellaneous graphical soil data, databases, maps, and reports for countries along with data only for individual countries. However, these data were generally classified using the USDA textural soil classification system, but not the USCS classification system. A partial list of the world soil classification system includes Israeli systems, USDA Soil Taxonomy, AASHTO System, USCS Classification by DoD, French systems, FAO system (Food and Agriculture Organization), Australian systems, Brazilian systems, British systems, Canadian systems, Dutch systems, German systems, and Russian systems, Chinese System, Korean System, and South African System.

The goal of this project was to create a worldwide soil database based on a unified engineering soil classification system of USCS. The soil data sources were divided into Tier 1 Data sources, Tier 2 data sources, and Tier 3 Data sources. Tier 1 Data (USCS data) have the highest quality and 
reliability because they were assembled from the USACE or USAF reports on actual data measurements that have been stored in the ERDC archive. Specific citations for these data are provided in the database. The sources for Tier 2 (USCS classified data) datasets are from published reports and articles from non-DoD sources, and theses references are also provided in the database. Tier 3 Data is comprised of soil data converted from alternative soil classification systems into equivalent USCS classification. The main source of Tier 3 (converted to equivalent USCS) data are from the ISRIC and SOTER database. These sources of soil data and other specific sources of data are described below.

\subsection{Data from the ERDC}

As part of several transportation engineering studies, the ERDC collected soil data from nearly 200 sites throughout the U.S. USCS classification was determined from the Atterberg Limits and sieve analysis. The ERDC authors noted that better classification can be determined if grain-size distribution is known above and beyond the textural designation. The soil data in ERDC storage were converted into Excel tables and were integrated into the MS Access ${ }^{\circledR}$ database (Tier 1 Data).

\subsection{U.S. Soil Survey Geographic soil data (SSURG0)}

U.S. Soil Survey Geographic soil data (SSURGO) contains information about soil collected by the National Cooperative Soil Survey. Information is available for most areas of the United States and its territories. Lab analysis was performed on many of the samples (http://www.nrcs.usda.gov/wps/portal/nrcs/main/soils/survey/geo/).

The SSURGO data are listed in both USCS and the USDA system. GarciaGaines and Frankenstein (2015) analyzed the SSURGO data to determine the frequency distribution of a given USDA classification in the USCS schema. Currently, these data are not available to include into the database described in this report.

\subsection{NSDB (National Soil Database)}

National Soil Database (NSDB) data contains soil, landscape, and climatic data for Canada and serves as the national archive for land resources information. It was collected by federal and provincial field surveys or 
created by land analysis projects (http://sis.agr.gc.ca/cansis/nsdb/index.html). These data were not available to include into the database.

\subsection{ASRIS (Australian Soil Resource Information System)}

The ASRIS database contains soil and land resource information from Australia. It was developed for a broad range of users, including natural resources managers, educational institutions, planners, researchers, and community groups (http://www.asris.csiro.au). These data were not available to include into the database.

\subsection{ISRIC - world soil information}

ISRIC - World Soil Information is an independent, science-based foundation. The institute was founded in 1966 following a recommendation of the International Soil Science Society (ISSS) and a resolution of the United Nations Educational, Scientific and Cultural Organization (UNESCO). ISRIC operates in three priority areas of: 1) soil data and soil mapping, 2) application of soil data in global development issues, and 3) training and education (http://www.isric.org/).

Data from different sources that were part of ISRIC were available for this project. The data were in Microsoft Access format, but all in the USDA textural soil classification system. The different ISRIC databases that were converted into Tier 3 Data for this database are described below.

\subsubsection{SOTER database}

The SOTER database (Oldeman and van Engelen 1993) established at scale 1:5000, ooo, contains digitized map units and their attribute data are available in Microsoft Access format. The SOTER program was initiated in 1986 by the FAO, the United Nations Environment Program (UNEP), and ISRIC under the aegis of the International Union of Soil Sciences (IUSS). Under the program, soil and terrain databases were compiled for Latin America and the Caribbean, Central and Eastern Europe, Southern Africa, Central Africa, as well as a number of specific countries. In 2008, these SOTER databases were incorporated in the Harmonized World Soil Database, a collaborative activity led by FAO, IIASA, ISRIC, JRC and ISCCAS. 
SOTER relies mainly on existing soil information. The data have been extracted from various published and unofficial sources by local experts and coded according to a globally developed system. Where no appropriate soil survey data existed, they were completed with remote sensing data. It is assumed that soils information extracted from most recent soil surveys.

As mentioned earlier, the SOTER soil data were used to generate Tier 3 Data for some countries included in this database. Table 10 provides a list of the soil group (soil type) of these data. The database (Tier 3) converts SOTER data to USCS equivalent soil classification.

\subsubsection{Harmonized World Soil Database (HWSD)}

The HWSD (FAO 2012) combines existing regional and national updates of soil information worldwide-SOTER, European Soil Database (ESDB), Soil Map of China, World Inventory of Soil Emission Potentials (WISE) with information contained within the FAO-UNESCO Soil. This database contains over 16,000 different soil-mapping units (http://www.iiasa.ac.at/web/home/research/modelsData/HWSD/HWSD.en.html).

The HWSD provides digital soil particle size distribution data for many countries in Microsoft Access format. These data were incorporated into the database described in this report as Tier 3 Soil Data. Table 15 provides description of soil classification group used in HWSD data. The database converts the classification groups of HWSD data into equivalent USCS classification.

Table 15. Recommended codes for the reference soil groups (WRB 2006).

\begin{tabular}{|l|l|l|c|}
\hline Soil Group & Soil Code & Description & Soil Code in Database \\
\hline Acrisol & AC & $\begin{array}{l}\text { Acrisols are soils that have a higher clay content in the } \\
\text { subsoil than in the topsoil as a result of pedogenetic } \\
\text { processes (especially clay migration) leading to an argic } \\
\text { subsoil horizon. }\end{array}$ & AC (WRB) \\
\hline Albeluvisol & AB & $\begin{array}{l}\text { Albeluvisols are soils that have, beginning within 1 m of } \\
\text { the soil surface, a clay illuviation horizon with an irregular } \\
\text { or broken upper boundary resulting in tonguing of } \\
\text { bleached soil material into the illuviation horizon. }\end{array}$ & AB (WRB) \\
\hline Alisol & AL & $\begin{array}{l}\text { Alisols are soils that have a higher clay content in the } \\
\text { subsoil than in the topsoil as a result of pedogenetic } \\
\text { processes (especially clay migration) leading to an argic } \\
\text { subsoil horizon. }\end{array}$ & AL (WRB) \\
\hline Andosol & AN & $\begin{array}{l}\text { Andosols accommodate the soils that develop in volcanic } \\
\text { ejecta or glasses under almost any climate (except under } \\
\text { hyperarid climate conditions). }\end{array}$ & AN (WRB) \\
\hline
\end{tabular}




\begin{tabular}{|c|c|c|c|}
\hline Soil Group & Soil Code & Description & Soil Code in Database \\
\hline Anthrosol & AT & $\begin{array}{l}\text { Anthrosols comprise soils that have been modified } \\
\text { profoundly through human activities, such as addition of } \\
\text { organic materials or household wastes, irrigation and } \\
\text { cultivation. }\end{array}$ & AT (WRB) \\
\hline Arenosol & AR & $\begin{array}{l}\text { Arenosols comprise sandy soils, including both soils } \\
\text { developed in residual sands after in situ weathering of } \\
\text { usually quartz-rich sediments or rock, and soils developed } \\
\text { in recently deposited sands such as dunes in deserts and } \\
\text { beach lands. }\end{array}$ & AR (WRB) \\
\hline Calcisol & $\mathrm{CL}$ & $\begin{array}{l}\text { Calcisols accommodate soils in which there is substantial } \\
\text { secondary accumulation of lime. Calcisols are common in } \\
\text { highly calcareous parent materials and widespread in arid } \\
\text { and semi-arid environments. Formerly used soil names for } \\
\text { many Calcisols include Desert soils and Takyrs. In the US } \\
\text { Soil Taxonomy, most of them belong to the Calcids. }\end{array}$ & $\mathrm{CL}(\mathrm{WRB})$ \\
\hline Cambisol & $\mathrm{CM}$ & $\begin{array}{l}\text { Cambisols combine soils with at least an incipient } \\
\text { subsurface soil formation. Transformation of parent } \\
\text { material is evident from structure formation and mostly } \\
\text { brownish discoloration, increasing clay percentage, } \\
\text { and/or carbonate removal. }\end{array}$ & $\mathrm{CM}$ (WRB) \\
\hline Chernozem & $\mathrm{CH}$ & $\begin{array}{l}\text { Chernozems accommodate soils with a thick black } \\
\text { surface layer that is rich in organic matter. The Russian } \\
\text { soil scientist Dokuchaev coined the name Chernozem in } \\
1883 \text { to denote the typical zonal soil of the tall grass } \\
\text { steppes in continental Russia. }\end{array}$ & $\mathrm{CH}$ (WRB) \\
\hline Cryosol & $\mathrm{CR}$ & $\begin{array}{l}\text { Cryosols comprise mineral soils formed in a permafrost } \\
\text { environment. Where water is present, it occurs primarily in } \\
\text { the form of ice. Cryogenic processes are the dominant } \\
\text { Soil-forming processes. }\end{array}$ & CR (WRB) \\
\hline Durisol & DU & $\begin{array}{l}\text { Durisols are associated mainly with old surfaces in arid } \\
\text { and semi-arid environments and accommodate very } \\
\text { shallow to moderately deep, moderately well- to well- } \\
\text { drained soils that contain cemented secondary silica } \\
\text { (SiO2) within } 100 \mathrm{~cm} \text { of the soil surface. }\end{array}$ & DU (WRB) \\
\hline Ferralsol & FR & $\begin{array}{l}\text { Ferralsols represent the classical, deeply weathered, red } \\
\text { or yellow soils of the humid tropics. These soils have } \\
\text { diffuse horizon boundaries, a clay assemblage dominated } \\
\text { by low-activity clays (mainly Kaolinite) and a high content } \\
\text { of sesquioxides. Local names usually refer to the color of } \\
\text { the soil. }\end{array}$ & FR (WRB) \\
\hline Fluvisol & $\mathrm{FL}$ & $\begin{array}{l}\text { Fluvisols accommodate genetically young, azonal soils in } \\
\text { alluvial deposits. The name Fluvisols may be misleading in } \\
\text { the sense that these soils are not confined only to river } \\
\text { sediments (Latin fluvius, river); they also occur in } \\
\text { lacustrine and marine deposits. }\end{array}$ & FL (WRB) \\
\hline
\end{tabular}




\begin{tabular}{|c|c|c|c|}
\hline Soil Group & Soil Code & Description & Soil Code in Database \\
\hline Gleysol & $\mathrm{GL}$ & $\begin{array}{l}\text { Gleysols are wetland soils that, unless drained, are } \\
\text { saturated with groundwater for long enough periods to } \\
\text { develop a characteristic gleyic color pattern. This pattern } \\
\text { is essentially made up of reddish, brownish or yellowish } \\
\text { colors at ped surfaces and/or in the upper soil layer or } \\
\text { layers, in combination with greyish/bluish colors inside } \\
\text { the peds and/or deeper in the soil. }\end{array}$ & GL (WRB) \\
\hline Gypsisol & GY & $\begin{array}{l}\text { Gypsisols are soils with substantial secondary } \\
\text { accumulation of gypsum (CaSO } 4.2 \mathrm{H} 2 \mathrm{O}) \text {. These soils are } \\
\text { found in the driest parts of the arid climate zone, which } \\
\text { explains why leading soil classification systems labeled } \\
\text { many of them Desert soils (former Soviet Union), and } \\
\text { Yermosols or Xerosols (FAO-UNESCO, 1971-1981). The } \\
\text { US Soil Taxonomy terms most of them Gypsids. }\end{array}$ & GY (WRB) \\
\hline Histosol & HS & $\begin{array}{l}\text { Histosols comprise soils formed in organic material. } \\
\text { These vary from soils developed in predominantly moss } \\
\text { peat in boreal, arctic and subarctic regions, via moss peat, } \\
\text { reeds/sedge peat (fen) and forest peat in temperate } \\
\text { regions to mangrove peat and swamp forest peat in the } \\
\text { humid tropics. Histosols are found at all altitudes, but the } \\
\text { vast majority occurs in lowlands. }\end{array}$ & HS (WRB) \\
\hline Kastanozem & KS & $\begin{array}{l}\text { Kastanozems accommodate dry grassland soils, among } \\
\text { them the zonal soils of the short-grass steppe belt, south } \\
\text { of the Eurasian tall grass steppe belt with Chernozems. } \\
\text { Kastanozems have a similar profile to that of Chernozems } \\
\text { but the humus-rich surface horizon is thinner than and not } \\
\text { as dark as that of the Chernozems and they show more } \\
\text { prominent accumulation of secondary carbonates. }\end{array}$ & KS (WRB) \\
\hline Leptosol & LP & $\begin{array}{l}\text { Leptosols are very shallow soils over continuous rock and } \\
\text { soils that are extremely gravelly and/or stony. Leptosols } \\
\text { are azonal soils and particularly common in mountainous } \\
\text { regions. }\end{array}$ & LP (WRB) \\
\hline Lixisol & LX & $\begin{array}{l}\text { Lixisols comprise soils that have a higher clay content in } \\
\text { the subsoil than in the topsoil as a result of pedogenetic } \\
\text { processes (especially clay migration) leading to an argic } \\
\text { subsoil horizon. Lixisols have a high base saturation and } \\
\text { low-activity clays at certain depths. }\end{array}$ & LX (WRB) \\
\hline Luvisol & LV & $\begin{array}{l}\text { Luvisols are soils that have a higher clay content in the } \\
\text { subsoil than in the topsoil as a result of pedogenetic } \\
\text { processes (especially clay migration) leading to an argic } \\
\text { subsoil horizon. Luvisols have high-activity clays } \\
\text { throughout the argic horizon and a high base saturation at } \\
\text { certain depths. }\end{array}$ & LV (WRB) \\
\hline Nitisol & NT & $\begin{array}{l}\text { Nitisols are deep, well-drained, red, tropical soils with } \\
\text { diffuse horizon boundaries and a subsurface horizon with } \\
\text { more than } 30 \text { percent clay and moderate to strong } \\
\text { angular blocky structure elements that easily fall apart } \\
\text { into characteristic shiny, polyhedric (nutty) elements. } \\
\text { Weathering is relatively advanced but Nitisols are far more } \\
\text { productive than most other red, tropical soils. }\end{array}$ & NT (WRB) \\
\hline
\end{tabular}




\begin{tabular}{|c|c|c|c|}
\hline Soil Group & Soil Code & Description & Soil Code in Database \\
\hline Phaeozem & $\mathrm{PH}$ & $\begin{array}{l}\text { Phaeozems accommodate soils of relatively wet grassland } \\
\text { and forest regions in moderately continental climates. } \\
\text { Phaeozems are much like Chernozems and Kastanozems } \\
\text { but are leached more intensively. Consequently, they have } \\
\text { dark, humus-rich surface horizons that, in comparison } \\
\text { with Chernozems and Kastanozems, are less rich in } \\
\text { bases. Phaeozems may or may not have secondary } \\
\text { carbonates but have a high base saturation in the upper } \\
\text { meter of the soil. }\end{array}$ & $\mathrm{PH}$ (WRB) \\
\hline Planosol & $\mathrm{PL}$ & $\begin{array}{l}\text { Planosols are soils with a light-colored, surface horizon } \\
\text { that shows signs of periodic water stagnation and abruptly } \\
\text { overlies a dense, slowly permeable subsoil with } \\
\text { significantly more clay than the surface horizon. The US } \\
\text { Soil Classification coined the name Planosols in 1938; its } \\
\text { successor, the US Soil Taxonomy, includes most of the } \\
\text { original Planosols in the Great Groups of the Albaqualfs, } \\
\text { Albaquults and Argialbolls. }\end{array}$ & PL (WRB) \\
\hline Plinthosol & PT & $\begin{array}{l}\text { Plinthosols are soils with plinthite, petroplinthite or } \\
\text { pisoliths. Plinthite is an Fe-rich (in some cases also Mn- } \\
\text { rich), humus-poor mixture of kaolinitic clay (and other } \\
\text { products of strong weathering such as gibbsite) with } \\
\text { quartz and other constituents that changes irreversibly to } \\
\text { a layer with hard nodules, a hardpan or irregular } \\
\text { aggregates on exposure to repeated wetting and drying. } \\
\text { Petroplinthite is a continuous, fractured or broken sheet } \\
\text { of connected, strongly cemented to indurated nodules or } \\
\text { mottles. }\end{array}$ & PT (WRB) \\
\hline Podzol & PZ & $\begin{array}{l}\text { Podzols are soils with a typically ash-grey upper } \\
\text { subsurface horizon, bleached by loss of organic matter } \\
\text { and iron oxides, on top of a dark accumulation horizon } \\
\text { with brown, reddish or black illuviated humus and/or } \\
\text { reddish Fe compounds. Podzols occur in humid areas in } \\
\text { the boreal and temperate zones and locally also in the } \\
\text { tropics. }\end{array}$ & PZ (WRB) \\
\hline Regosol & RG & $\begin{array}{l}\text { Regosols form a taxonomic remnant group containing all } \\
\text { soils that could not be accommodated in any of the other } \\
\text { Reference Soil Groups (RSGs). In practice, Regosols are } \\
\text { very weakly developed mineral soils in unconsolidated } \\
\text { materials that do not have a mollic or umbric horizon, are } \\
\text { not very shallow or very rich in gravels (Leptosols), sandy } \\
\text { (Arenosols) or with fluvic materials (Fluvisols). Regosols } \\
\text { are extensive in eroding lands, particularly in arid and } \\
\text { semi-arid areas and in mountainous terrain. }\end{array}$ & RG (WRB) \\
\hline Solonchak & SC & $\begin{array}{l}\text { Solonchaks are soils that have a high concentration of } \\
\text { soluble salts at some time in the year. Solonchaks are } \\
\text { largely confined to the arid and semi-arid climate zones } \\
\text { and to coastal regions in all climates. Common } \\
\text { international names are saline soils and salt-affected } \\
\text { soils. In national soil classification systems, many } \\
\text { Solonchaks belong to: halomorphic soils (Russian } \\
\text { Federation), Halosols (China), and Salids (United States of } \\
\text { America). }\end{array}$ & $\mathrm{SC}$ (WRB) \\
\hline
\end{tabular}




\begin{tabular}{|c|c|c|c|}
\hline Soil Group & Soil Code & Description & Soil Code in Database \\
\hline Solonetz & $\mathrm{SN}$ & $\begin{array}{l}\text { Solonetz are soils with a dense, strongly structured, clayey } \\
\text { subsurface horizon that has a high proportion of adsorbed } \\
\mathrm{Na} \text { and/or Mg ions. Solonetz that contain free soda } \\
\text { (Na2CO3) are strongly alkaline (field pH }>8.5 \text { ). Common } \\
\text { international names are alkali soils and sodic soils. }\end{array}$ & SN (WRB) \\
\hline Stagnosol & ST & $\begin{array}{l}\text { Stagnosols are soils with a perched water table showing } \\
\text { redoximorphic features caused by surface water. } \\
\text { Stagnosols are periodically wet and mottled in the topsoil } \\
\text { and subsoil, with or without concretions and/or bleaching. } \\
\text { A common name in many national classification systems } \\
\text { for most Stagnosols is pseudogley. In the US Soil } \\
\text { Taxonomy, many of them belong to the Aqualfs, Aquults, } \\
\text { Aquents, Aquepts and Aquolls. }\end{array}$ & ST (WRB) \\
\hline Technosol & $\mathrm{TC}$ & $\begin{array}{l}\text { Technosols comprise a new RSG and combine soils whose } \\
\text { properties and pedogenesis are dominated by their } \\
\text { technical origin. They contain a significant amount of } \\
\text { artefacts (something in the soil recognizably made or } \\
\text { extracted from the earth by humans), or are sealed by } \\
\text { technic hard rock (material created by humans, having } \\
\text { properties unlike natural rock). They include soils from } \\
\text { wastes (landfills, sludge, cinders, mine spoils and ashes), } \\
\text { pavements with their underlying unconsolidated } \\
\text { materials, soils with geomembranes and constructed soils } \\
\text { in human-made materials. Technosols are often referred } \\
\text { to as urban or mine soils. }\end{array}$ & TC (WRB) \\
\hline Umbrisol & UM & $\begin{array}{l}\text { Umbrisols accommodate soils in which organic matter has } \\
\text { accumulated within the mineral surface soil (in most } \\
\text { cases with low base saturation) to the extent that it } \\
\text { significantly affects the behavior and utilization of the soil. } \\
\text { Umbrisols are the logical counterpart of soils with a mollic } \\
\text { horizon and a high base saturation throughout } \\
\text { (Chernozems, Kastanozems and Phaeozems). }\end{array}$ & UM (WRB) \\
\hline Vertisol & VR & $\begin{array}{l}\text { Vertisols are churning, heavy clay soils with a high } \\
\text { proportion of swelling clays. These soils form deep wide } \\
\text { cracks from the surface downward when they dry out, } \\
\text { which happens in most years. }\end{array}$ & VR (WRB) \\
\hline
\end{tabular}

\subsubsection{ISRIC-WISE harmonized global soil profile dataset}

The ISRIC-WISE database (Batjes 2008) was compiled from a wide range of soil profile data collected by many soil professionals worldwide. All profiles have been harmonized with respect to the original Legend (1974) and Revised Legend (1988) of FAO-UNESCO. The primary soil data and any secondary data derived from them can be linked using GIS to the spatial units of the soil map of the world as well as more recent Soil and Terrain (SOTER) database through the soil legend code. As cited by ISRIC-WISE (Batjes 2008), strict quality-control measures were applied in developing this database, but ISRIC does not warrant that the data are 
error-free. These soil data are classified and grouped according to the World Reference Base (WRB) (2006) as described in Section 3.5.4.

\subsubsection{World Reference Base (WRB) for soil resources (WRB 2006)}

In the period 1998-2006, the WRB became the official reference for soil nomenclature and soil classification for the European Commission and was adopted by the west and central African Soil Science Association as the preferred tool to harmonize and exchange soil information in the region. The main text was translated into 13 languages (Chinese, French, German, Hungarian, Italian, Japanese, Latvian, Lithuanian, Polish, Rumanian, Russian, Spanish, and Vietnamese) and adopted as a higher level of the national soil classification system in a number of countries (e.g., Italy, Mexico, Norway, Poland, and Vietnam).

The WRB (2006) provides digital particle size distribution data for many countries, which were included as Tier 3 Data. WRB (2006) data has the same soil classification group as HWSD soil data (Table 15). The database converts these group classifications into equivalent USCS soil classification. The database has options to show both the original soil data group and the converted to USCS group for selected countries and regions. 


\section{Database Structure}

A user interface was developed using Microsoft Access 2013 to allow users to search the database by geographic locator. Microsoft Access was chosen because of its availability and versatility as a relational database application. The majority of the data sources were prepared or available in MS Excel ${ }^{\circledR}$ tables and then be integrated into Microsoft Access.

The database includes several tables of the data, which can be expanded as more data are added. The current version of the database separates the U.S. soil data from the rest of world soil data. The soil tables are named based on the data quality ranking of Tier 1, Tier 2, and Tier 3 .

\subsection{Tier 1 dataset}

Tier 1 Data are engineering soil data assembled from verified U.S. reports on exact site locations from countries around the world and the U.S. These Tier data include soil classification data based on the USCS. The current database has Tier 1 Data for 53 countries and all 50 states of the U.S., including Washington D.C. and Puerto Rico, but excluding West Virginia because data were not available. Tier 1 Data includes USCS soil classification and other soil parameters, such as: CBR, $k$, Dry Density, Moisture Content, LL, PI, \% Passing \#200, and aggregate properties, and etc.

The Tier 1 Data were stored in MS Excel ${ }^{\circledR}$ tables with the following information and format.

- Country Code - The ISO country code (two letters combination) are internationally recognized codes that designates for each country and most of the dependent areas a two letter combination or a three letter combination.

- Country Region - Name of site, airport, road, etc. Often the name in the report is dated, search for the newest name of the site and have both the new name followed by old name in parenthesis.

- Nearest City - Name of the nearest major city.

- Latitude of Region - General latitude of the site. The units are either decimal degrees or degrees, minutes, and seconds (e.g., 31.61 or $\left.31^{\circ} 38^{\prime} \mathrm{N}\right)$. 
- Longitude of Region - General longitude of the site. The units are either decimal degrees or degrees, minutes, and seconds (e.g., 66.39 or $\left.65^{\circ} 43^{\prime} \mathrm{E}\right)$.

- Description - A general description of the subgrade soils (in top $100 \mathrm{~cm}$ ) at the site.

- Classification System - Classification system, for example: USCS, or AASHTO.

- Soil Type - Classification code or value. For example, if USCS: GP, CL, SM, SP, SC, SP-SM, etc. If AASHTO: A-1-a, A-4, A-6, etc.

- California Bearing Ratio (CBR) (\%) - Evaluated (recommended or selected) conservative design value for CBR of the subgrade at the site.

- Average CBR (\%) - Average CBR of several values of the subgrade measured from multiple locations at the site.

- Minimum CBR (\%) - Minimum CBR of the subgrade measured at the site.

- Maximum CBR (\%) - Maximum CBR of the subgrade measured at the site.

- CBR Method - Indicated here how the CBR was determined, for example: field (in place), lab, soaked, unsoaked, CPT (cone penetration test), DCP (dynamic cone penetrometer), etc.

- Soaked Field CBR (\%) - Recommended (or selected) value for the laboratory soaked CBR of the subgrade at the site. If a selected value is not provided, an average was calculated.

- Min Soaked Field CBR (\%) - Minimum field soaked CBR of the subgrade measured at the site.

- Unsoaked Field CBR (\%) - Recommended value for the field unsoaked CBR of the subgrade at the site. If a selected value is not provided, an average was calculated from provided values for multiple sampling locations.

- Min Unsoaked Field CBR (\%) - Minimum field unsoaked CBR of the subgrade at the site.

- Max Unsoaked Field CBR (\%) - Maximum field unsoaked CBR at the site.

- Lab CBR (\%) - Recommended (or selected) value for the laboratory determined CBR of the subgrade at the site. This column was used if the lab methods of $100 \%, 95 \%$, or $90 \%$ were not specified. Typically this is a 4-day socked CBR value.

- $\quad$ 100\% Lab CBR (\%) - Selected value for the laboratory determined $100 \%$ CBR of the subgrade at the site. Typically this is a 4-day socked CBR value. 
- 95\% Lab CBR (\%) - Selected value for the laboratory determined 95\% CBR of the subgrade at the site. Typically this is a 4-day socked CBR value.

- $\quad$ 90\% Lab CBR (\%) - Selected value for the laboratory determined 90\% CBR of the subgrade at the site. Typically this is a 4-day socked CBR value.

- $\quad \boldsymbol{k}$ (pci) - The recommended (or measured) value modulus of subgrade reaction $k$ in pounds per square inch per inch. If no recommended value is given, the average $k$ of the subgrade at the site is provided.

- Minimum $\boldsymbol{k}$ (pci) - Minimum $k$ value at the site in pounds per square inch per inch.

- Maximum $\boldsymbol{k}$ (pci) - Maximum $k$ value at the site in pounds per square inch per inch.

- Dry Density (pcf) - The average dry weight density of the subgrade in pounds per cubic foot.

- Gravimetric Moisture Content (\%) - The engineering gravimetric moisture content.

- Subgrade Aggregate Properties - The aggregate properties of the subgrade. For example, hardness, abrasion, reactability, calcium content, laterites, base rock CBR \%, etc.

- Construction Aggregate Properties - The aggregate properties in the surrounding area, which can be used in construction.

- Liquid Limit (\%) - Average liquid limit for the subgrade at the site.

- Plasticity Index (\%) - Average plasticity index for the subgrade at the site.

- \%passing \#200 sieve- Range of values passing a \#200 sieve.

- Short Reference- Short reference of the source of the data, for example: USACE, 1964; USAFCESA, 1995; Golder Associates, 2015; etc.

- Long Reference- Long reference for the source of the data, for example: US Air Force Civil Engineer Support Agency (USAFCESA), 1995. Airfield Pavement Evaluation: Cairo East Air Base, Egypt, July 1995.

\subsection{Tier 2 dataset}

Tier 2 Soil Data have USCS classification, but the data were collected from sources that cannot be verified for quality. These data were collected from other countries' reports, websites, and published articles. The Tier 2 data were stored in MS Excel ${ }^{\circledR}$ tables with the information and format as provided above for the Tier 1 Data. 


\subsection{Tier 3 dataset}

Tier 3 Soil Data do not have USCS soil classification, but soils data reported in alternative classification systems such as agricultural and geological classification systems. However, the database developed here is for engineering use, the Tier 3 Data were converted to the USCS soil classification system using some scientific and engineering assumptions and formulations as described in Section 4.3.1.

\subsubsection{Converting non-USCS to USCS classification system}

Converting the USDA and other soil classification systems to the USCS classification system without knowledge of the Atterberg Limits of the soils requires some assumptions of the soil characteristics, the mineralogy of the soil, etc. Section 2.8 describes some of the research studies on converting USDA soil classification data to USCS soil classification.

Previously, under another project at ERDC, a formulation was developed to convert soil data for the country of Liberia from USDA to USCS classification. The same developed procedure was programmed into the database. Table 16 outlines the basic steps, and the text below describes assumptions used. Note that these conversion formulations have not been validated with field data as no soil samples from the regions studied have been sampled and tested using USCS procedures. However, the developed procedure is based on USCS soil type characteristics and criteria that were used as a means of verification for quality and correctness.

\subsubsection{Conversion procedure}

The conversion procedure used here is given as a reference guide to direct further investigation and should not be relied upon solely without visual/manual classification techniques before conducting operations.

Table 16. Conversion procedure from USDA to USCS classification.

\begin{tabular}{|l|l|}
\hline Description & Action Processes \\
\hline & \% Gravel \\
Soil Input Parameters & \% Sand \\
& \% Silt \\
& \% Clay \\
\hline Plasticity Index (PI) & Soil Activity Parameter, A \\
\hline
\end{tabular}




\begin{tabular}{|c|c|}
\hline Description & Action Processes \\
\hline Check for Pure Silt or Clay & $\begin{array}{l}\text { IF (\%Clay+ \% Silt) > 50\% Then Check, } \\
\text { IF (\%Silt times } 2>\% \text { Clay) } \rightarrow \text { Silt } \\
\text { IF (\%Silt times } 2<\% \text { Clay) } \rightarrow \text { Clay }\end{array}$ \\
\hline Check either SM/SC or GM/GC & $\begin{array}{l}\text { IF (\%Clay + \%Silt) }<50 \text { and (\%Clay + \%Silt) }>12 \text {, } \\
\text { Then, } \\
\text { IF (\%Sand }<\% \text { Gravel) } \rightarrow \text { GM or GC } \\
\text { Otherwise } \rightarrow \text { SM or SC } \\
\text { IF (\%Clay + \%Silt) }<12 \text { and (\%Clay + \%Silt) }>5 \\
\rightarrow \text { Dual Soil Type, } \\
\text { Not (GM/GC or SM/SC) }\end{array}$ \\
\hline Check for fines designation of $\mathrm{M}$ or $\mathrm{C}$ & $\begin{array}{l}\text { IF (\%Silt times } 2>\% \text { Clay }) \rightarrow \mathrm{M} \\
\text { IF (\%Silt times } 2<\% \text { Clay }) \rightarrow \mathrm{C}\end{array}$ \\
\hline Final Check for USCS Equivalent Soil Type & $\begin{array}{l}\text { IF Step 3) provides SM or SC Then } \\
\text { IF Step 4) Provides C } \rightarrow \text { SC } \\
\text { IF Step 4) Provides M } \rightarrow \text { SM } \\
\text { IF Step 3) provides GM or GC Then } \\
\text { IF Step 4) Provides C } \rightarrow \text { GC } \\
\text { IF Step 4) Provides M } \rightarrow \text { GM } \\
\text { IF Step 3) Provides DUAL, Then } \\
\text { IF Step 4) Provides M, Then } \\
\text { IF \%Gravel > \%Sand } \rightarrow \text { GP-GM } \\
\text { Otherwise SP-SM } \\
\text { IF Step 3) Provides DUAL, Then } \\
\text { IF Step 4) Provides C, Then } \\
\text { IF \%Gravel > \%Sand } \rightarrow \text { GP-GC } \\
\text { Otherwise SP-SC } \\
\text { IF Step 2) Provides Clay, Then } \\
\text { IF Step 1) > 30, } \rightarrow \text { CH } \\
\text { Otherwise, } \rightarrow \text { CL } \\
\text { IF Step 2) Provides Silt, } \rightarrow \text { ML }\end{array}$ \\
\hline
\end{tabular}

1. Table 16, step 2) and step 4) check whether the soil type is silty or clayey. The soil is ranked as fine-grained if $50 \%$ or more passes the \#200 sieve. A delineation between silt and clay attributes was made based on the relative percentage of one fraction to another. It was assumed that if there was twice as much silt fraction as clay, then the soil would behave in a silty manner (with an $\mathrm{M}$ designation) and if not, then the soil would behave like a clay (a $\mathrm{C}$ designation). This breakdown is based solely on 
experience and a need to define some threshold at which this behavior could be observed if Atterberg Limits would be available for these soils.

"M" classification if \%Silt $>2 * \%$ Clay otherwise "C" classification

2. The PI of a soil sample can be estimated if the (colloidal) activity and the amount of the clay fraction are known. A breakdown of clay mineralogy from the parent soils of a region where these core samples are taken reveals percentages of Kaolinite, Illite, and Montmorillonite. These clay minerals have varying degrees of plasticity that contribute to the stickiness of the fine-grained matrix. Activity values for the clay minerals can be estimated also using published information (Table 3 ). The PI of the soil was related to Activity (A) and the clay content (\%Clay) by the following relationship:

$$
P I=A * \% \text { Clay }(\text { clay fraction })(\text { Reference: Skempton }, 1953)
$$

3. Based on the calculated PI value (step 1) (Table 16), fine-grained clay soils can be classified (step 5) (Table 16) as low-plasticity clay (CL) if the PI $\leq$ $30 \%$ and high plasticity clay $(\mathrm{CH})$ if the $\mathrm{PI}>30 \%$. This criteria was subjective based on the average vertical break between $\mathrm{CL}$ and $\mathrm{CH}$ soils on a plasticity chart. Any soil that had an $\mathrm{M}$ designation is assumed to be of low plasticity and classified as an ML. There are MH soils found in some regions especially within tropical zones, but they are difficult to quantify from the formulations provided here and criteria must be developed later.

4. The soil can be checked for other types if it contains various proportions of sand, gravel, silt and clay (with at least 12\% fines). If the soil has more sand than gravel, it is either SM or SC. Otherwise, it is either a GM or GC. The difference between $\mathrm{M}$ and $\mathrm{C}$ is based on the percentage of silt and clay fractions as noted in the outline number 1 . If there was twice as much as silt than clay, the soil was labels SM or GM; otherwise, it was classified as a SC or GC.

5. If the percentage of fines falls between 5 and $12 \%$, the soil receives a dual classification (step 5) (Table 16). If the percentage of gravel is more than percentage of sand, it is classified as a gravel soil (Table 16) and based on the silt or clay percentage they can be classified as either GPGM or GP-GC. If the percentage of sand is more than percentage of gravel, it is classified as a sandy soil (Table 16) and based on the silt or clay percentage they can be classified as either SP-SM or SP-SC. Note 
that the gravel or sand fraction here are assumed poorly graded. The soil types may change if soil gradation is known (Section 2.2.6).

The above approach was formulated as a general way to convert non-USCS data to the USCS classification system (Tier 3), where Tier 1 and Tier 2 data were not available. 


\section{Database User Interface}

A user interface was developed using Microsoft Access 2013 to display soil data in a user-friendly software. The soil data can be viewed and printed but not edited. The interface integrates tables of soil data and provides easy access to the data. The use of this database requires Microsoft Access software installed on the user's computer. The user interface requires a username and password (Figure 6). If the username and password are accepted, then the interface allows the user to access the main database and options (Figure 7).

Currently, the standalone database provides five main options. These options are (1) Soil Data of Region of a Country, (2) Soil Data for a Whole Country, (3) Search Locations by Latitude and Longitude, (4) Documents and Reports, and (5) Open Directory and Files. The first option allows users to select data for a region of a country. The second option allows users to get only Tier 1 Data for all regions of a country of interest. The third option allows user to search for soil information by location based on given latitude and longitude. The fourth option gives access to the users' computer directory ( $\mathrm{C}: \backslash$ Soi 1 DataBase $\backslash \mathrm{Hel}$ ) where guidelines and documentations are stored. The fifth option allows user to go to any directory and file or website of the computer in use.

\subsection{Soil data of a country (region by region)}

The first option of the database main menu contains features for different Tier data selections. The options include Tier 1 Soil Data, Tier 2 Soil Data, and Tier 3 Soil Data for all countries that data were available. The Tier 1 Data for U.S. states were separated from the world data and are available under the USA Soil Data option (Figure 6). Selecting Tier 1 Soil Data brings up a dialog box like that shown in Figure 8. Selecting Tier 2 Soil Data brings up a dialog box like that shown in Figure 9. Selecting Tier 3 Data brings up a dialog box like that shown in Figure 10. Selecting USA soil data brings up a dialog box as shown in Figure 11. 
Figure 6. Database login view.

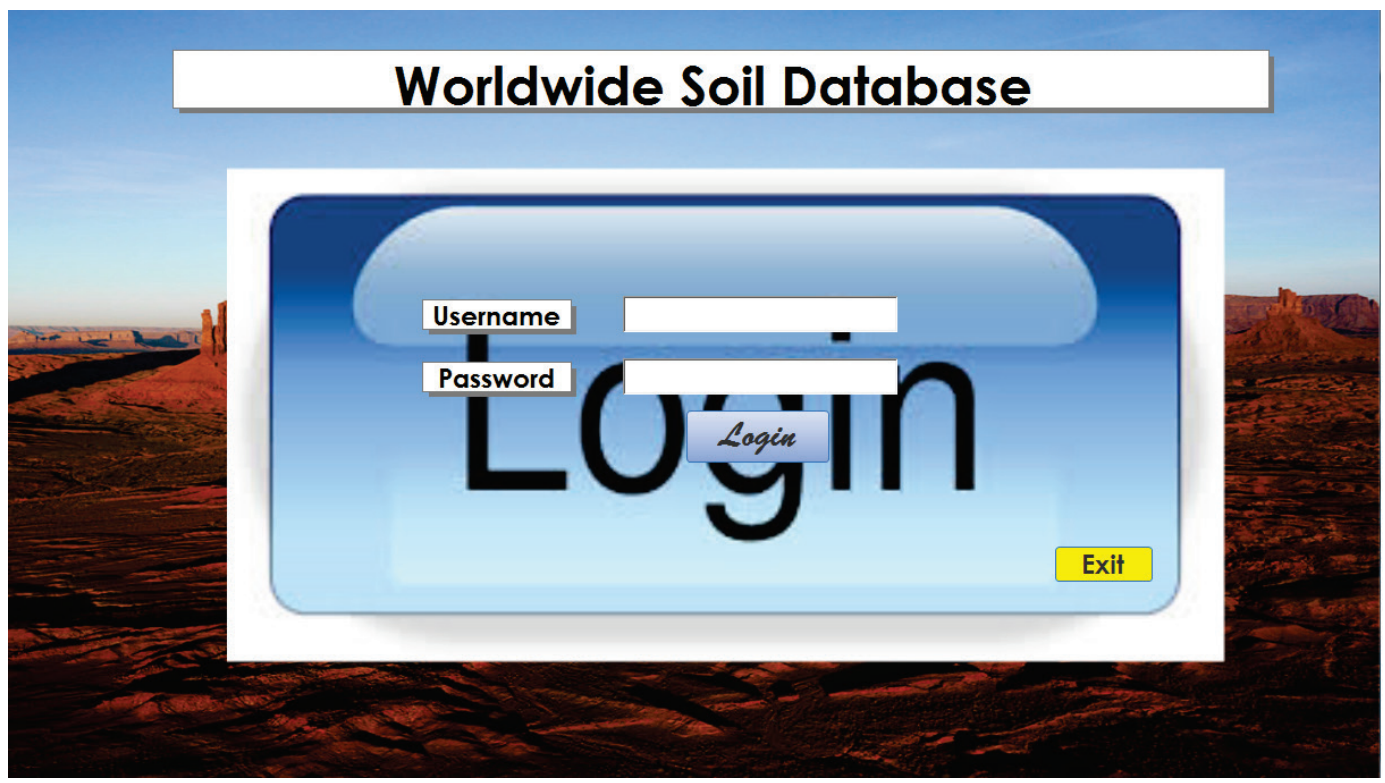

Figure 7. Main menu of the database options.

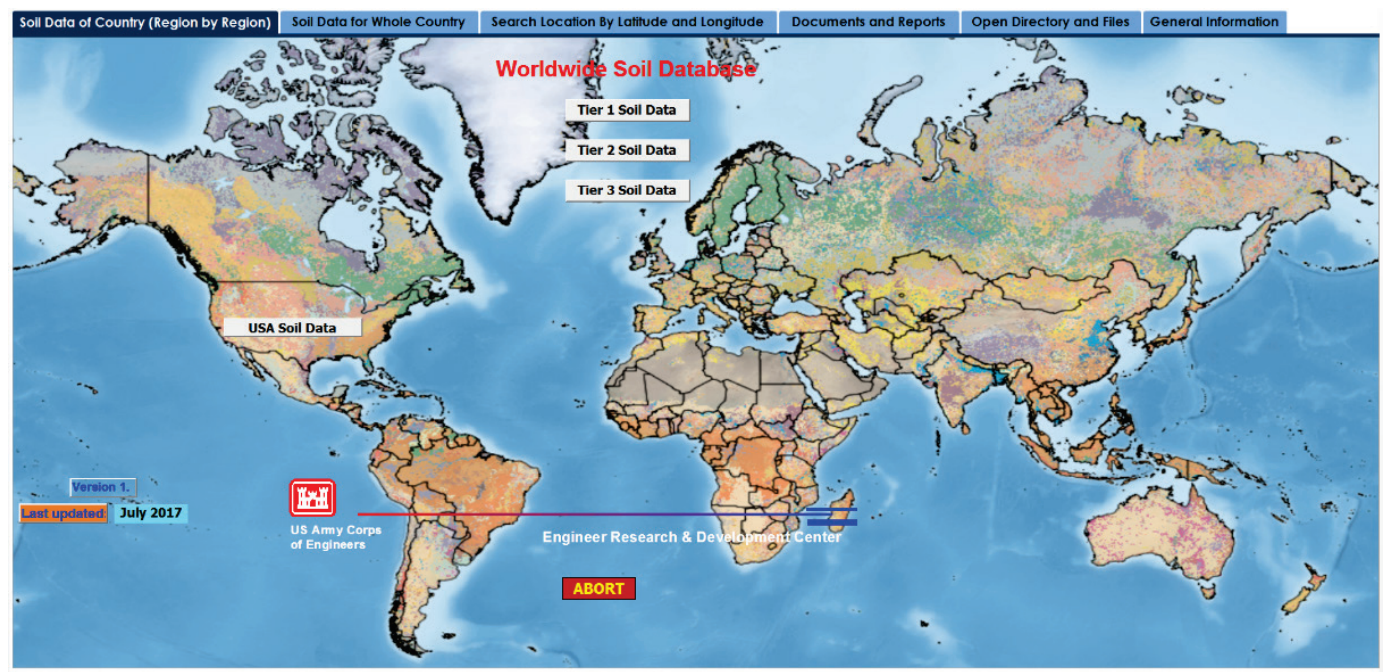


Figure 8. Tier 1 Soil Data display options.

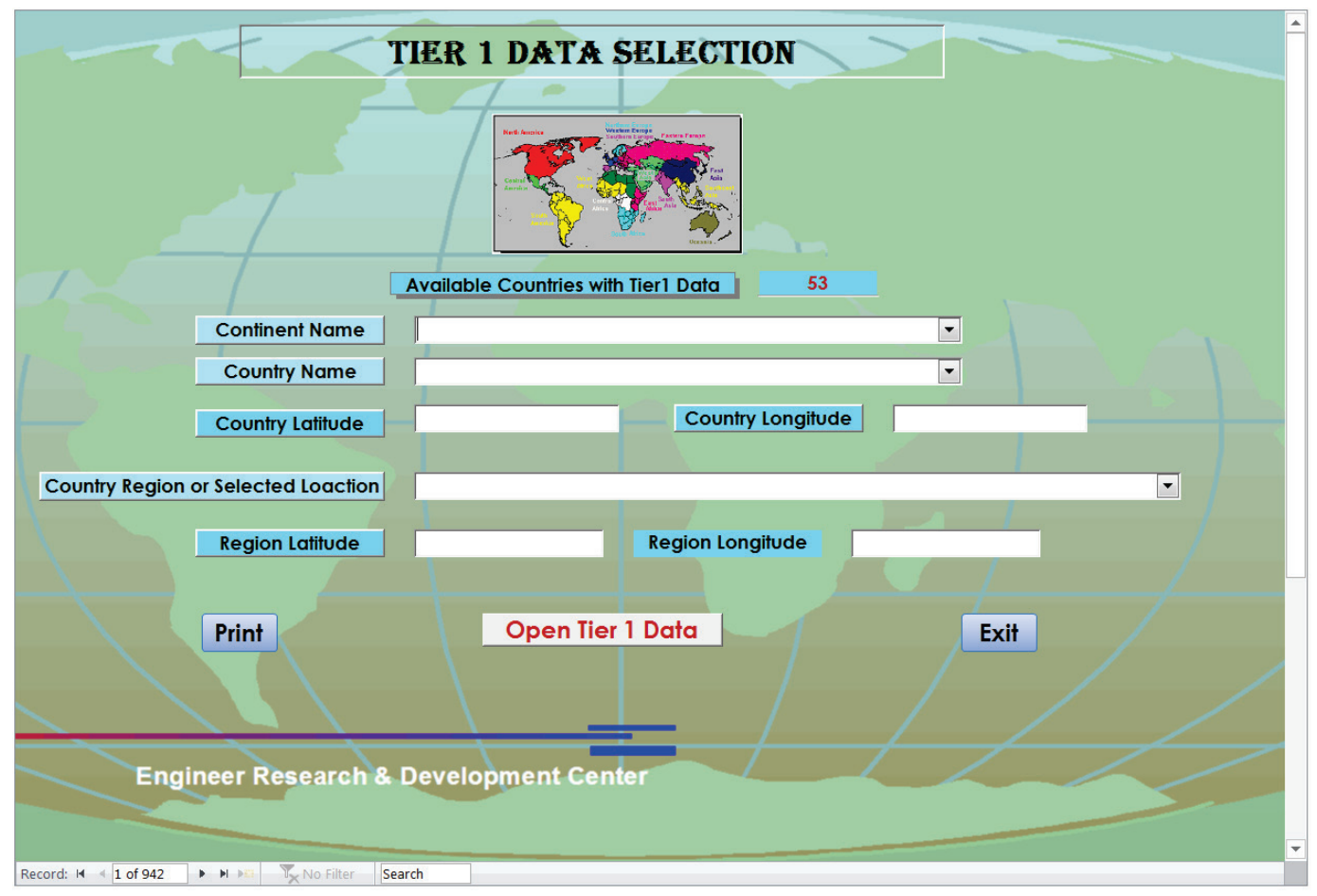

Figure 9. Tier 2 Soil Data display options.

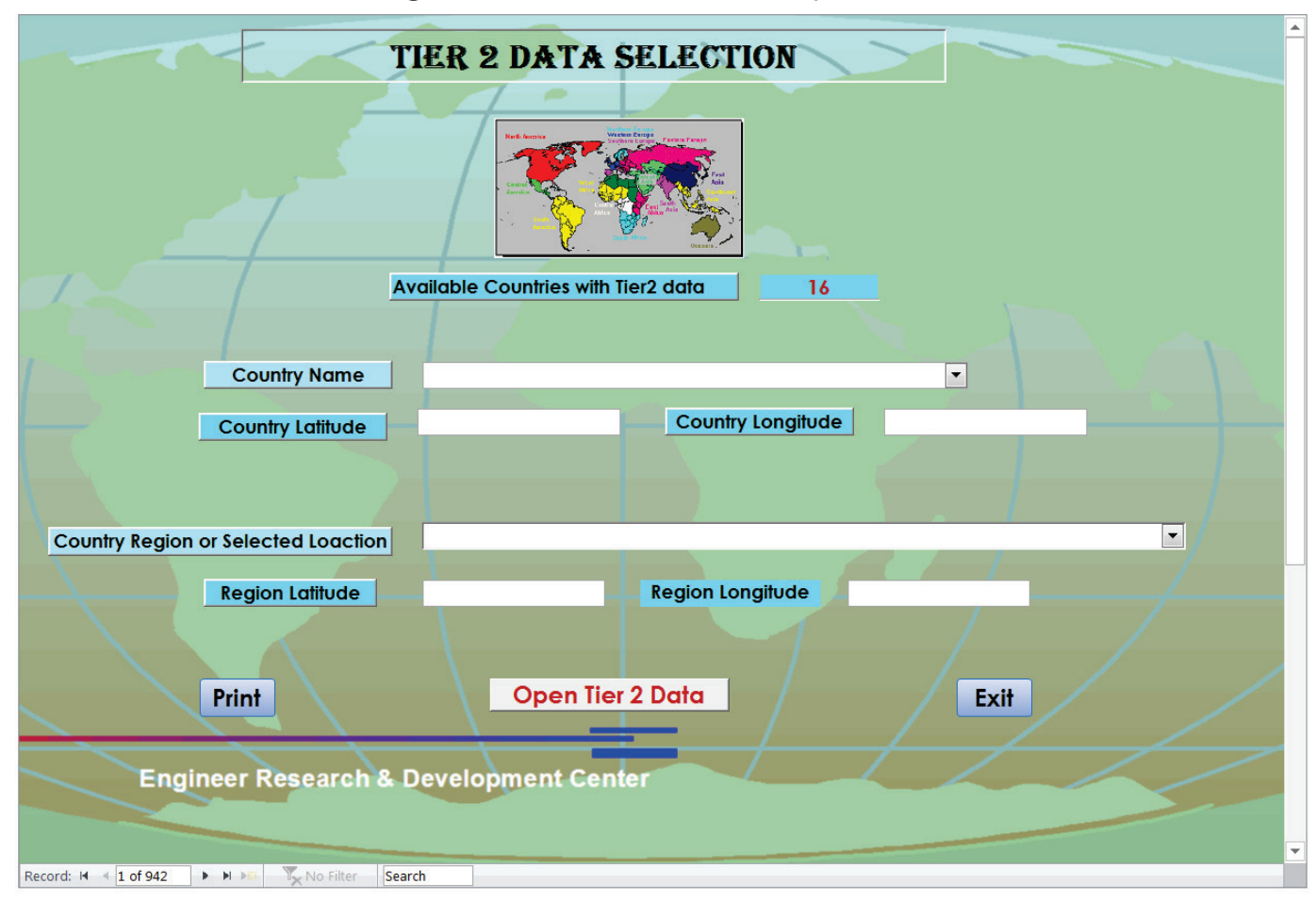


Figure 10. Tier 3 Soil Data display options.

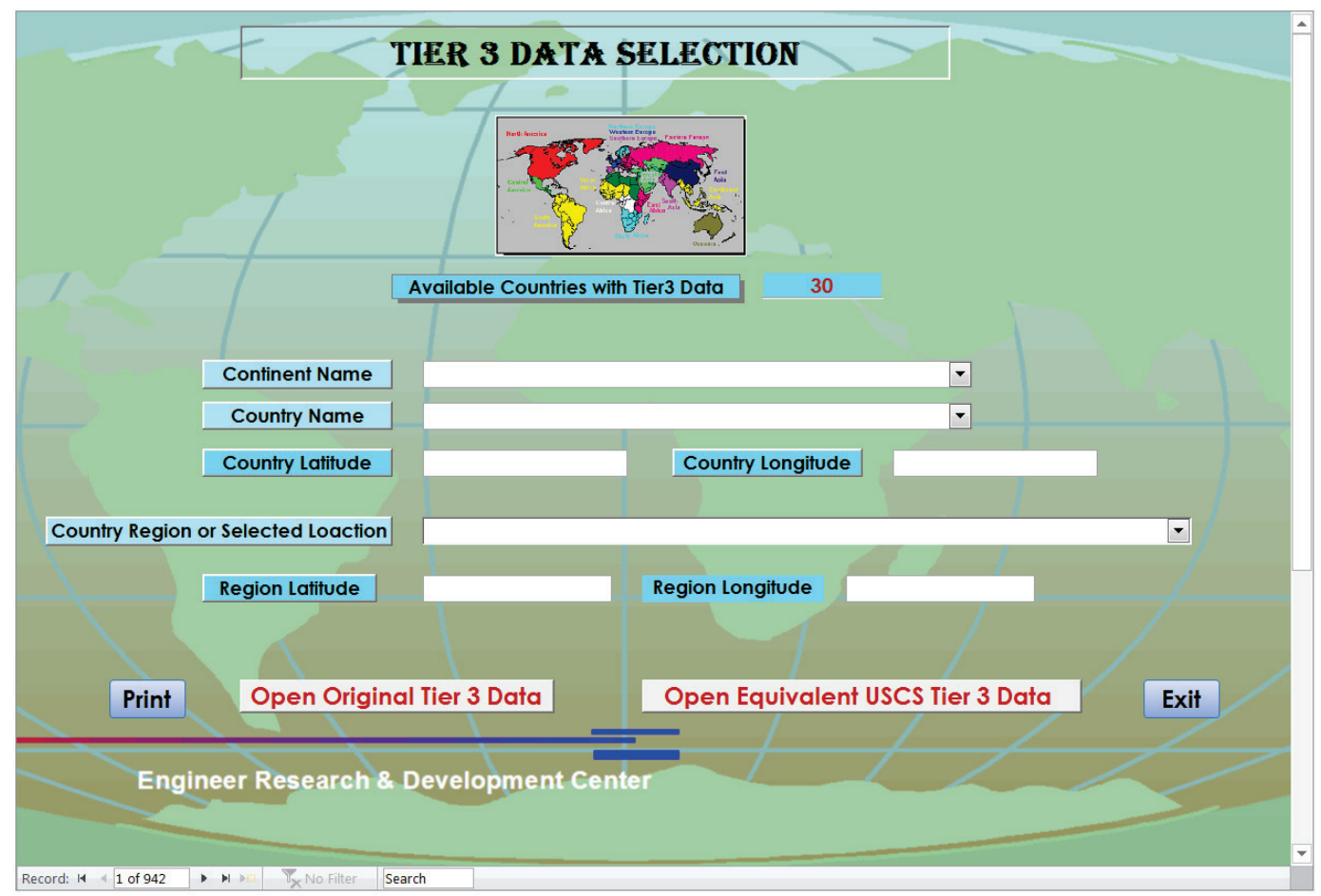

Figure 11. Tier 1 USA soil data display options.

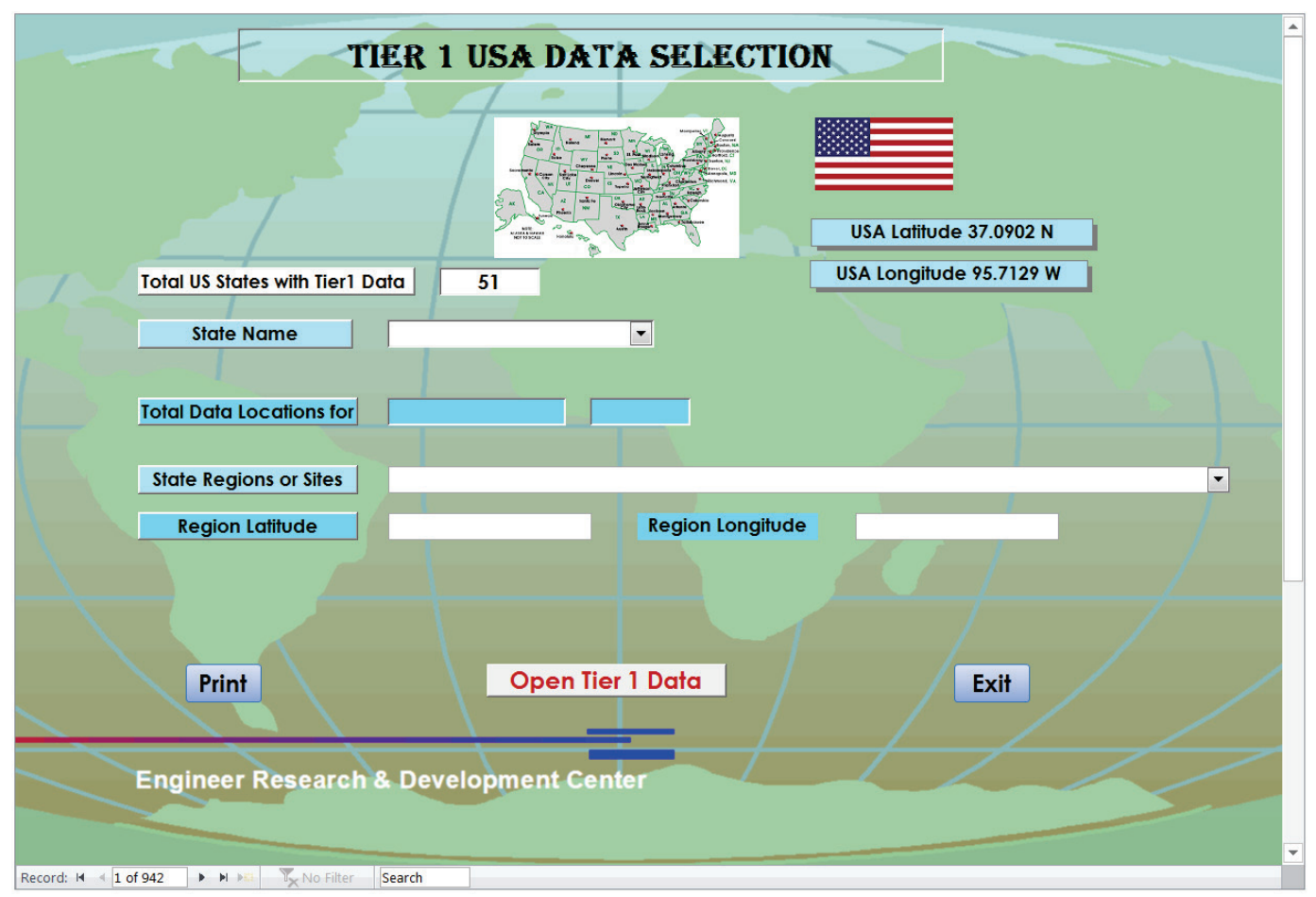




\subsubsection{Example of Tier 1 Data Selection}

The Tier 1 Data Selection Option (Figure 12) displays options to select a location of interest with a wealth of data integrated from the multiple data sources described in Chapter 4. The Tier 1 Data can be selected from available lists in world continent, country, and region of a country. Once the continent of interest has been chosen, the user can chose a country of interest and then a region of the selected country (Figure 12), and finally after selection of continent, country, and region, the user can select the Open Tier 1 Data, the soil data for that region will be displayed as an example in Figure 13 and Figure 14. The user also has an option to print information of Tier 1 Soil Data or Exit the display. This option provides soil data for one region of country at a time when it applies. There is another option in the database that user can get soil data for all regions of a country once.

Figure 12. Example of Tier 1 Data Selection.

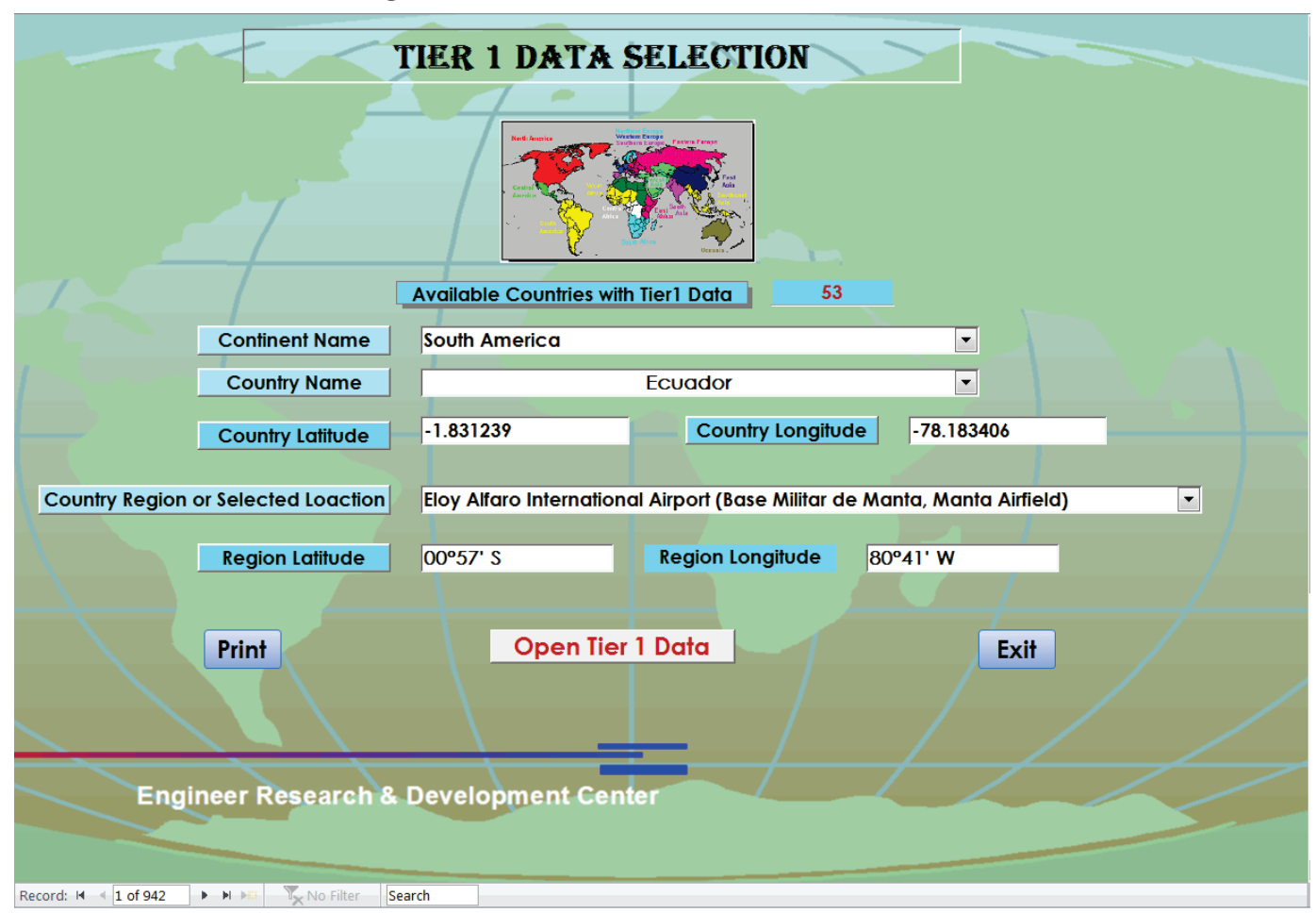


Figure 13. Example Tier 1 Soil Data (Page 1).

\begin{tabular}{|c|c|c|c|c|c|}
\hline \multicolumn{6}{|c|}{ Tier 1 Soil Data } \\
\hline & & & $\mathrm{N}$ & 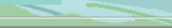 & \\
\hline Country Name & Ecuado & Country Region & \multicolumn{3}{|c|}{ |Eloy Alfaro International Airport (Base Militar de Manta, Manta Airfield) } \\
\hline Country Latitude & -1.831239 & Latitude Region & $00^{\circ} 57^{\prime} \mathrm{S}$ & & \multirow{3}{*}{ Exit } \\
\hline \multirow[t]{2}{*}{ Country Longitude } & -78.18340 & Longitude Region & $80^{\circ} 41^{\prime} \mathrm{W}$ & Print & \\
\hline & & Nearest City & Manta & & \\
\hline Classification System & \multicolumn{2}{|l|}{ UsCS } & Lab CBR (\%) & & \\
\hline Soil Type & \multicolumn{2}{|c|}{$\mathrm{CL}, \mathrm{sC}$} & $100 \%$ Lab CBR (\%) & & \\
\hline \multirow[t]{2}{*}{ Description } & \multicolumn{2}{|c|}{ sandy clays and low-plastic clays } & $95 \%$ Lab CBR (\%) & & \\
\hline & & & $90 \%$ Lab CBR (\%) & & \\
\hline CBR (\%) & \multicolumn{2}{|l|}{10} & $k$ (pci) & & \\
\hline Average CBR (\%) & & & Minimum $\mathrm{k}$ (pci) & 175 & \\
\hline Minimum CBR (\%) & 9 & & Maximum $\mathrm{k}(\mathrm{pci})$ & 250 & \\
\hline Maximum CBR (\%) & 27 & & Dry Density (pcf) & & \\
\hline CBR Method & DCP & & Gravimetric Moisture Content (\%) & & \\
\hline \multicolumn{3}{|l|}{ Soaked Field CBR (\%) } & Subgrade Aggregate Properties & & \\
\hline \multicolumn{2}{|l|}{ Min Soaked Field CBR (\%) } & & Construction Aggregate Properties & & \\
\hline \multicolumn{2}{|c|}{ Max Soaked Field CBR (\%) } & & Liquid Limit (\%) & & \\
\hline
\end{tabular}

Figure 14. Example Tier 1 Soil Data (Page 2).

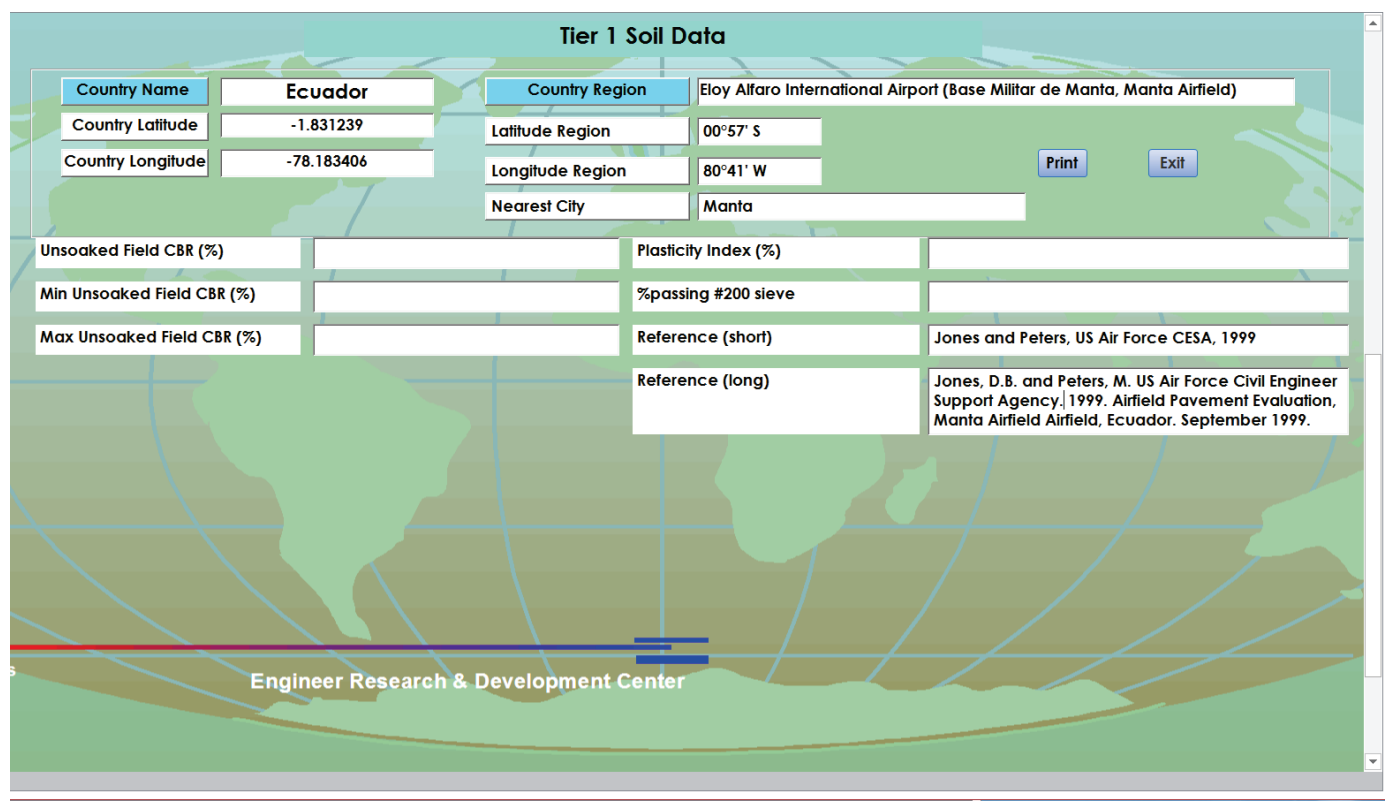

\subsubsection{Example of Tier 2 data selection}

The Tier 2 Soil Data, as described in Section 4.2, are from non-verified sources and typically have fewer soil parameters reported when compared to the Tier 1 Data. Therefore, the Tier 2 data selection display dialog (Figure 9) box looks different than those designed for the Tier 1 Data Selection (Figure 8) and does not list the continents. The data can only be selected from the provided list of countries but not the world continents. 
As an example, Figure 15 displays the selection of Tier 2 Soil Data for the country of Turkey. Once the country of interest (here, Turkey) has been chosen, the user can chose the region of the selected country (ex. Eminonu [Station $1 / 2$ ]) and finally, by clicking the Open Tier 2 Data, the soil data for that region will be displayed (Figure 16 and Figure 17). The user also has an option to print display soil data of Tier 2 or Exit the display.

Figure 15. Example of Tier 2 data selection.

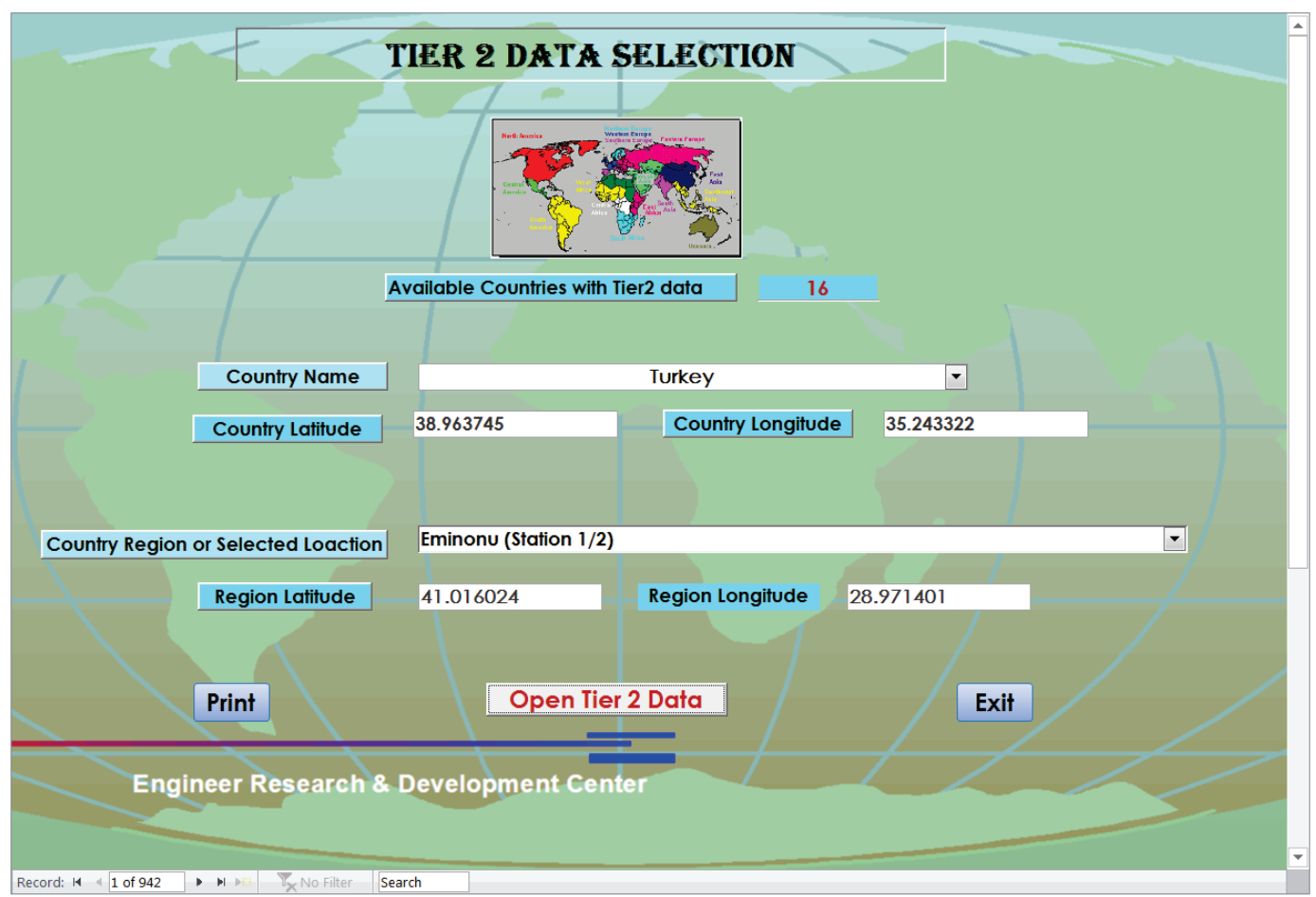

Figure 16. Example Tier 2 Soil Data (Page 1).

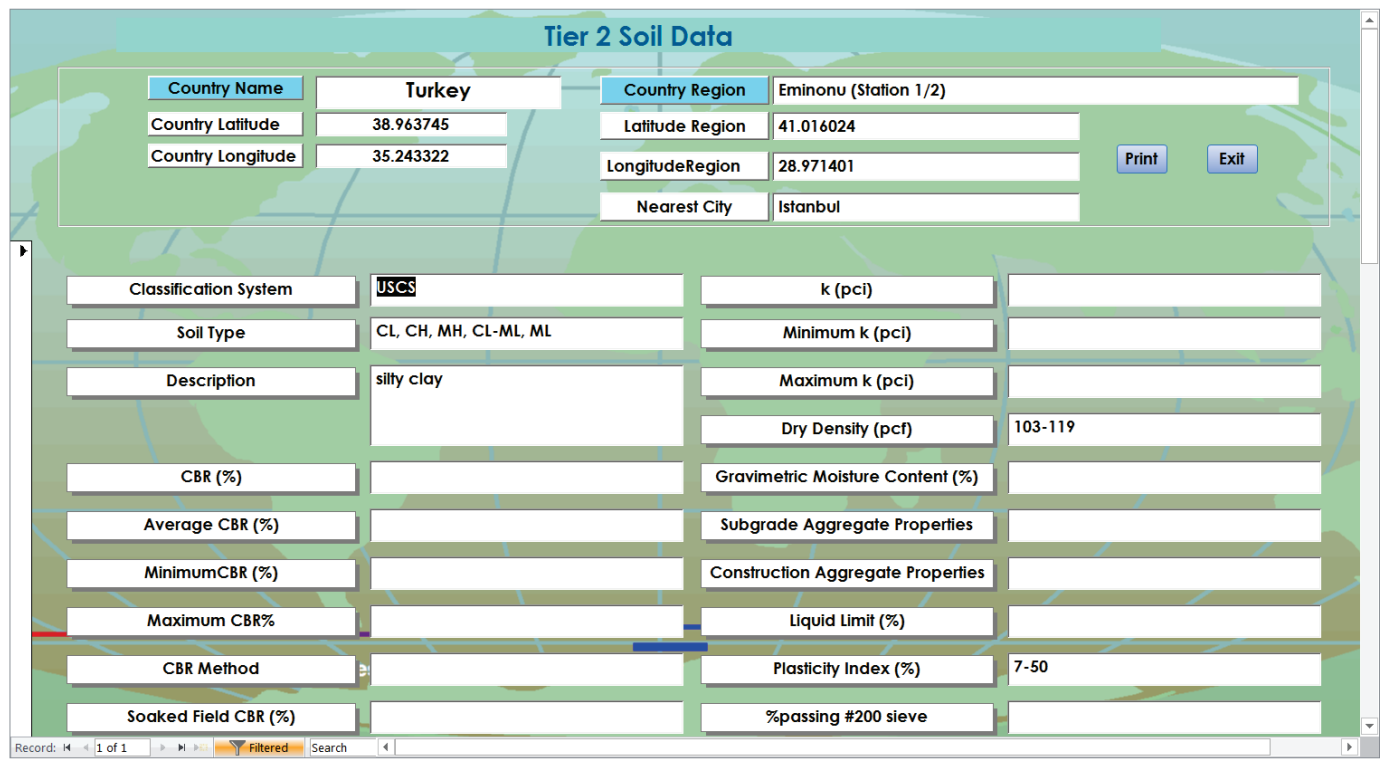


Figure 17. Tier 2 Soil Data for example data selection (Page 2).

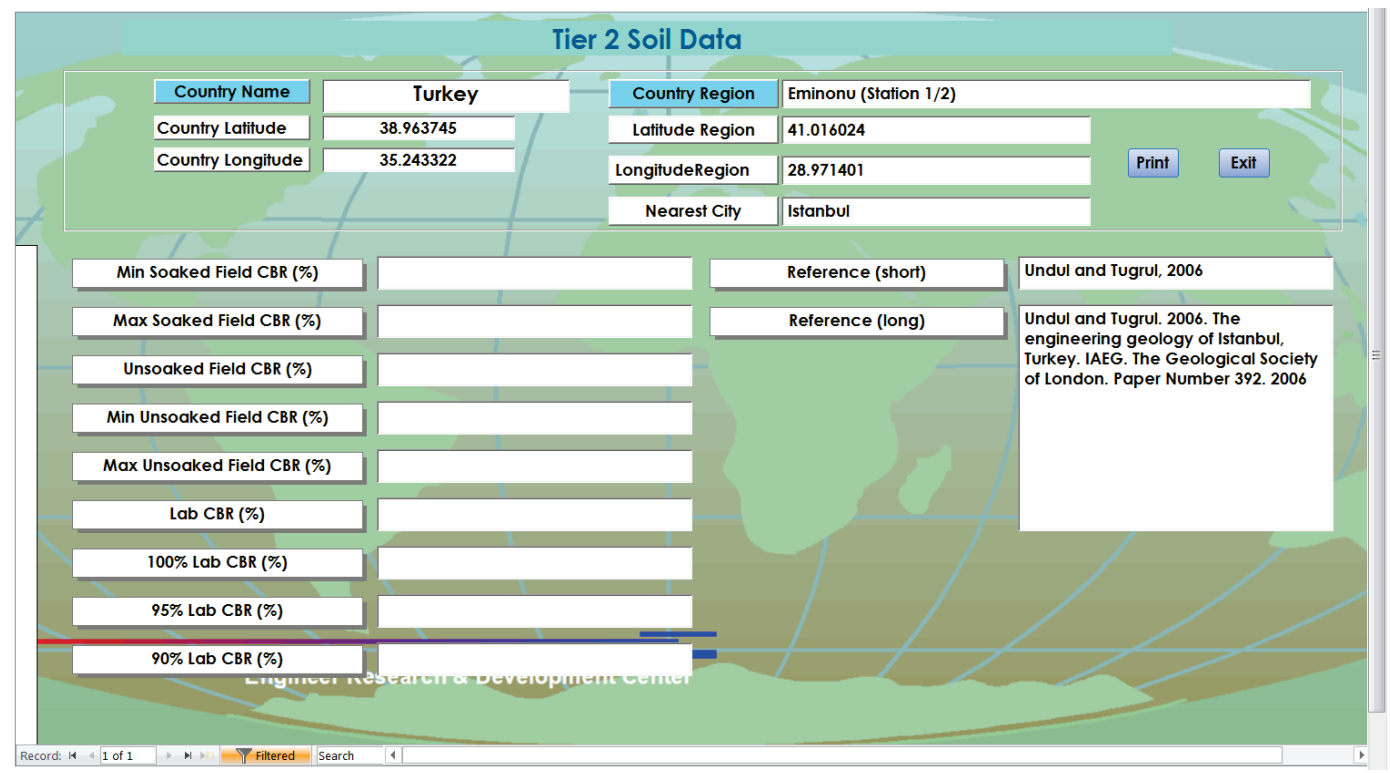

\subsubsection{Example of Tier 3 Data selection}

Tier 3 Data (as described in Section 4.3) are converted from the other soil classifications into a probable USCS soil classification. The majority of soil data around the world are not reported in terms of USCS. Hence, the converted Tier 3 Data can fill data gaps in the database where Tier 1 and Tier 2 data do not exist. A formulation was developed that converts the non-USCS soil data available in the Tier 3 Soil Data. However, the formulation and calculation require soil activity data, which are normally are not available with the soil data (see Sections 2.3 and 4.3.1).

To access Tier 3 Soil Data for a country and region, the user first selects a continent from the provided list (Figure 18). Then, the user selects a country (e.g., Rwanda) and then select a region of interest for this country (e.g., RW.07-068.0008). After these selections, the user can either click Open Original Tier 3 Data or Open Equivalent USCS Tier 3 Data. If the user selects the latter, a display dialog of USCS Tier 3 Soil Data will open (Figure 19). Again, the display data can be printed using Print option or be exited using Exit option. 
Figure 18. Example of Tier 3 Data selection.

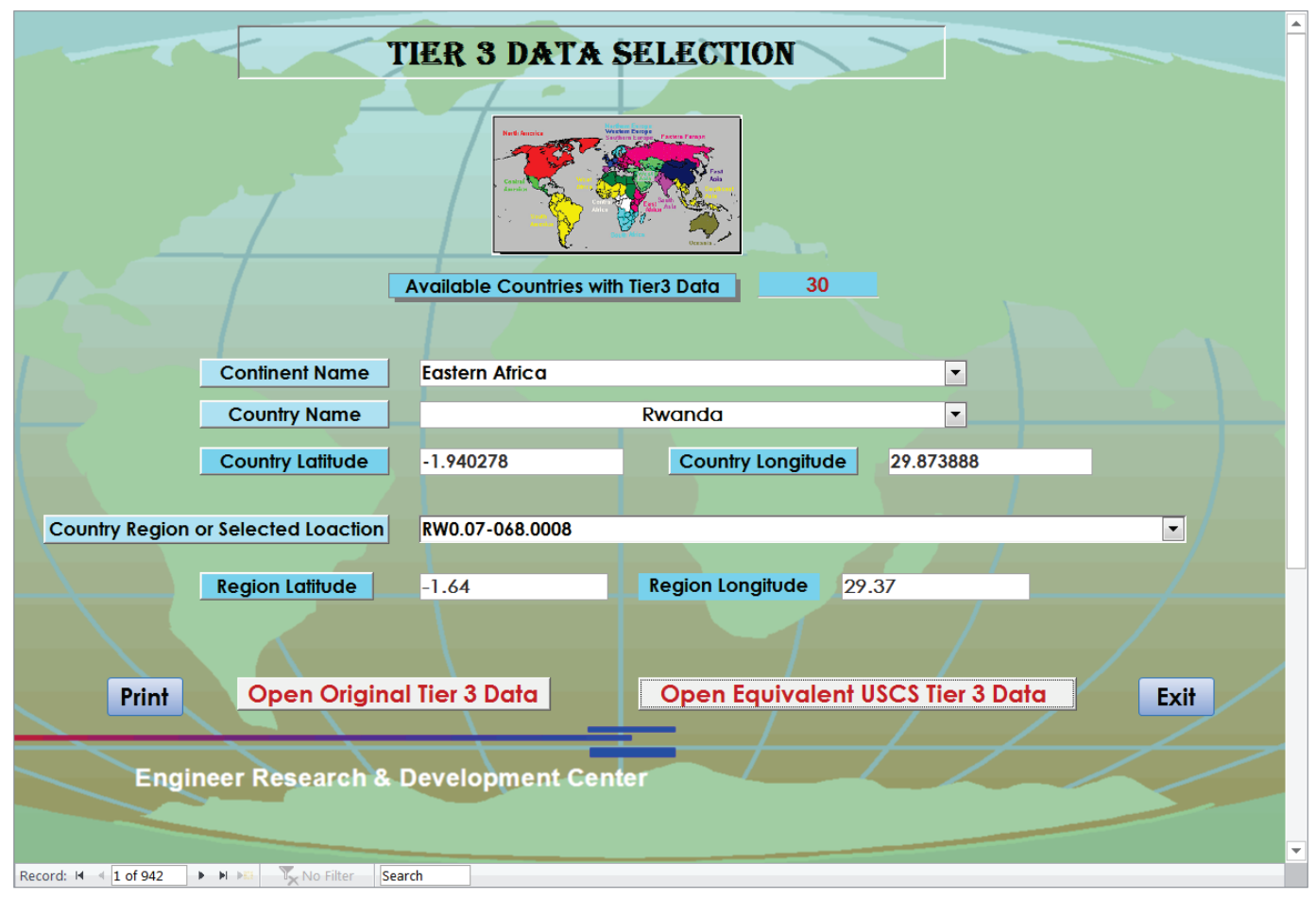

Figure 19. Tier 3 Soil Data for example data selection.

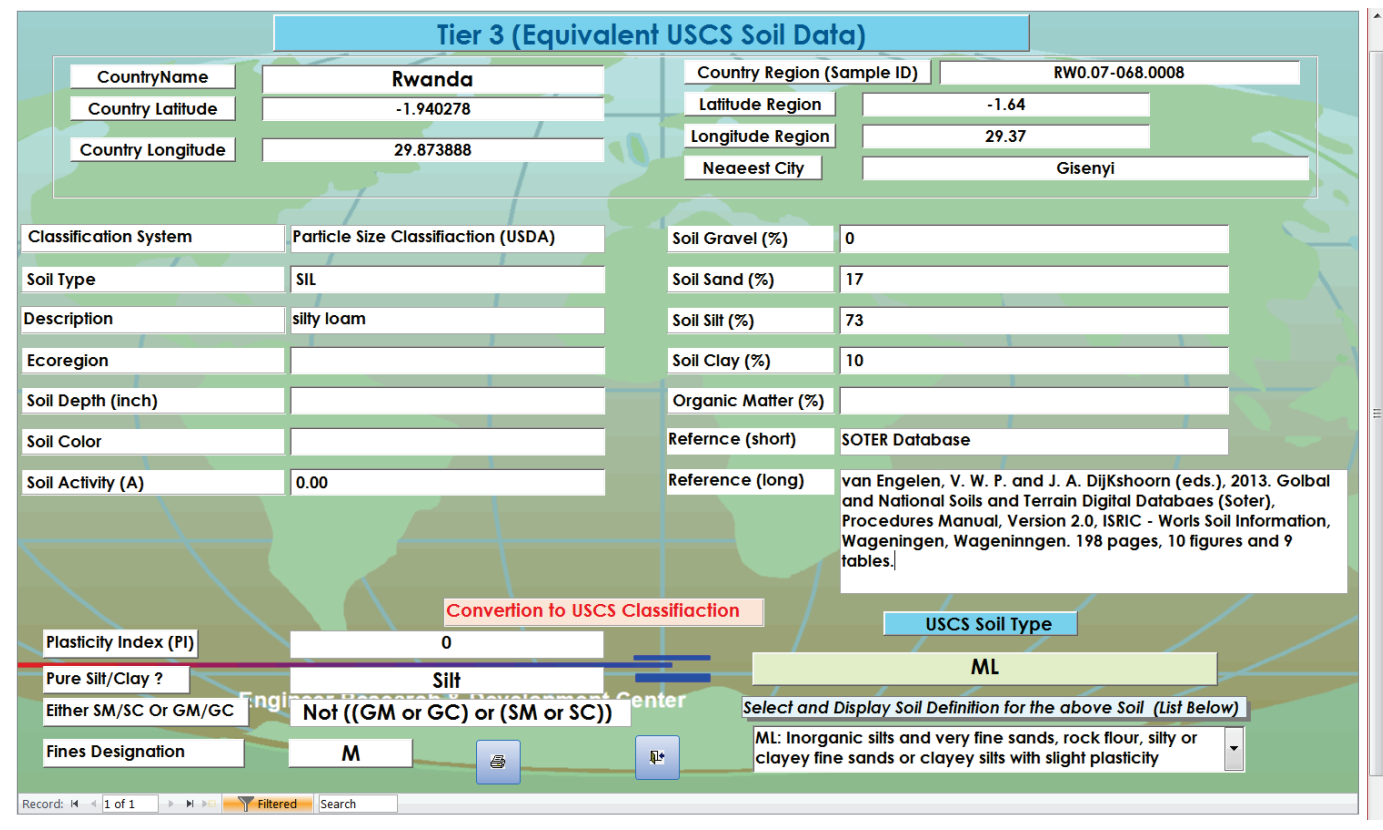




\subsubsection{Example of USA data selection}

All U.S. soil data were available from trusted and verified sources (ERDC archive databases). The U.S. data were separated from other world countries data because of the unique formation of states and regions. The display dialog Figure 20 will open if the user choses USA Soil Data from the main display menu (Figure 7). As an example here, the State of Alabama was selected from the provided list of states (State Name). Figure 20 shows that there are 43 data locations for the State of Alabama (Total Data Locations for Alabama $=43$ ). The user then can select a region or site location from the provided list (e.g., Cairns Army Airfield (Station 2/3)). By clicking the option Open Tier 1 Data (Figure 20), the data for Cairns Army Airfield (Station 2/3) is displayed in Figure 21. The region's name shows that this location is station 2 of 3 stations at this site (Station 2/3). Again, the user can print this display by clicking the Print option or can exit by clicking the Exit option.

Figure 20. USA soil data selections display dialog.

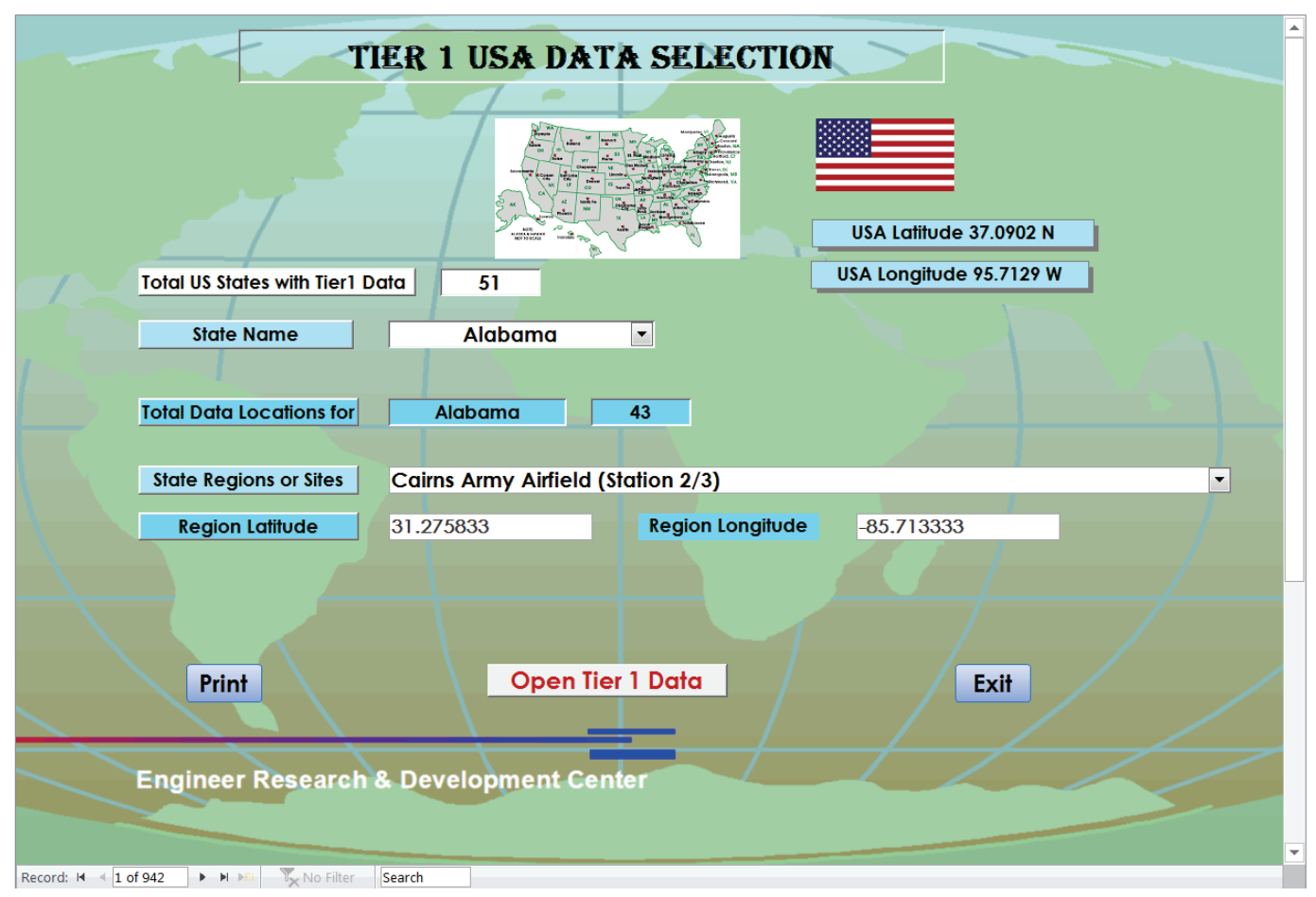


Figure 21. Example Tier 1 Soil Data for a site in State of Alabama, USA.

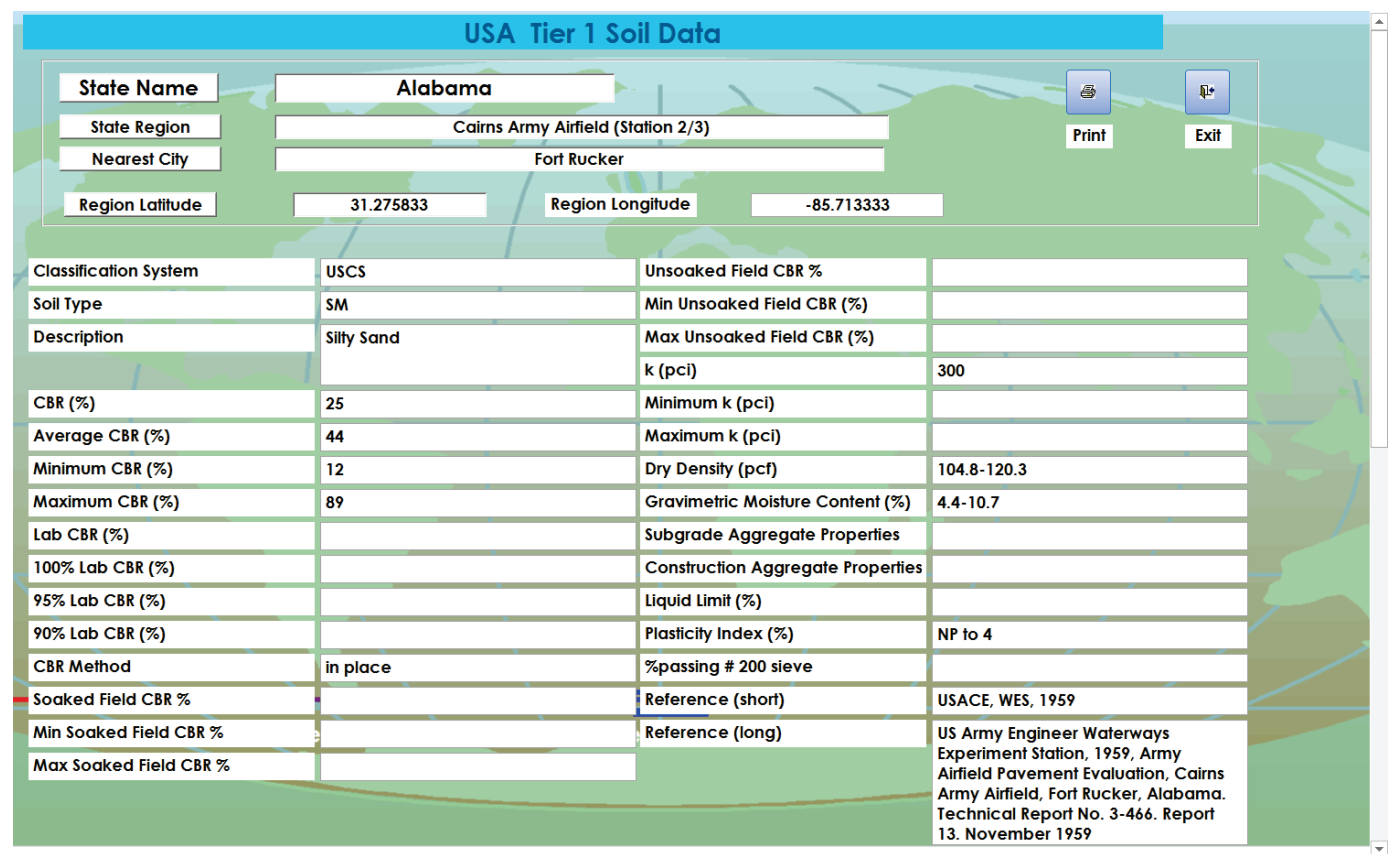

\subsection{Soil data for whole country}

The database provides an option to summarize Tier 1 Soil Data for all regions of a country in one file, which can be viewed, saved as PDF file, and/or printed using a selected or default printer. Figure 22 shows an example of the selection of Tier 1 Soil Data for all regions of Denmark. First, from the main display menu of the database select the option Soil Data for Whole Country (Figure 22). The display shows the available number of countries with Tier 1 Data is 53. Then the user can select a country, here Denmark, which has four regions populated with soil sample locations. After selecting the country, the user has two options: to view the data (View Tier 1 Data) or save it in a PDF file for printing (Click for Printable Report of Tier 1 Soil Data). Figure 22 shows the selection options, and Figure 23 displays the soil data for all regions or samples of Denmark stored in the database. 
Figure 22. Database option to select soil data for whole country.

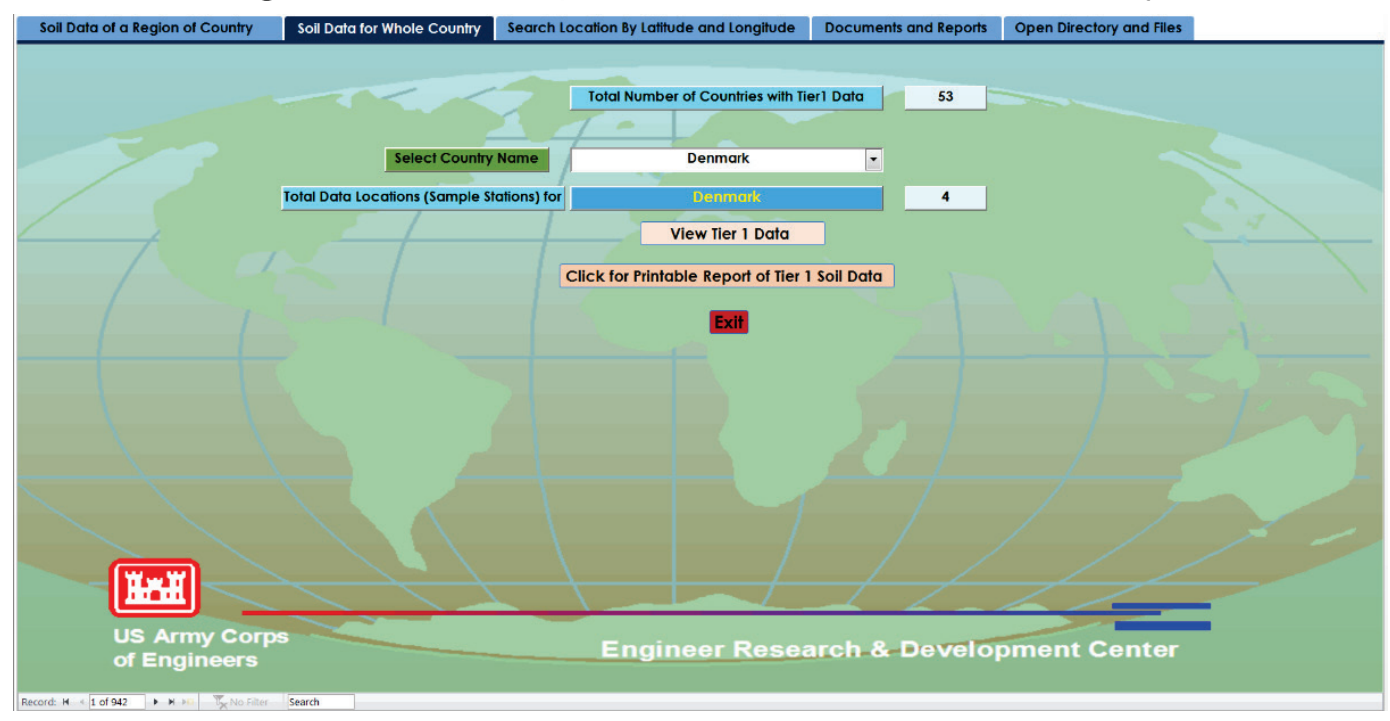

Figure 23. Database option of Soil Data for Whole Country. View Tier 1 Data for Denmark (4 Regions, one region for each Figure below).

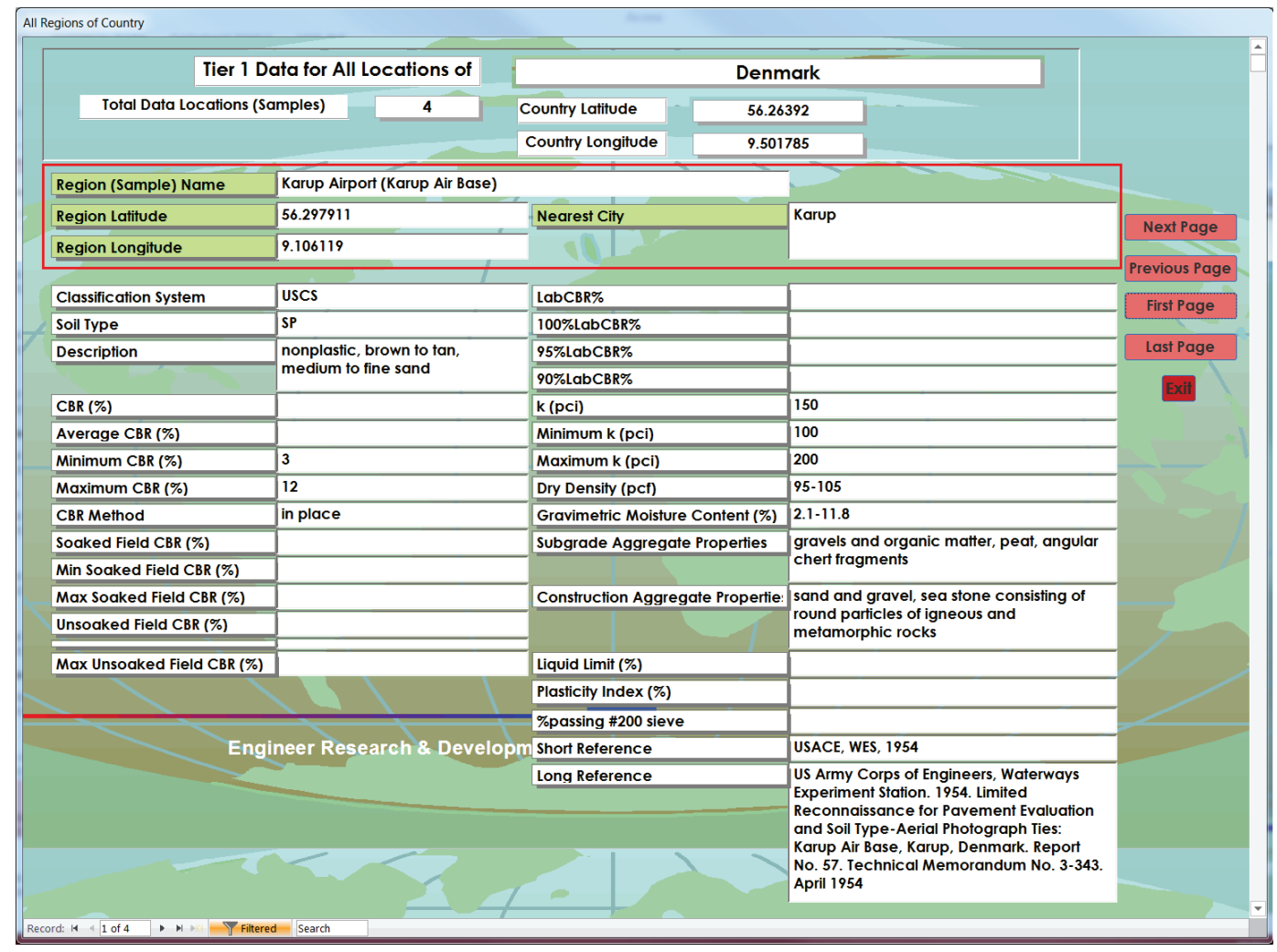


Figure 23. (Cont.)

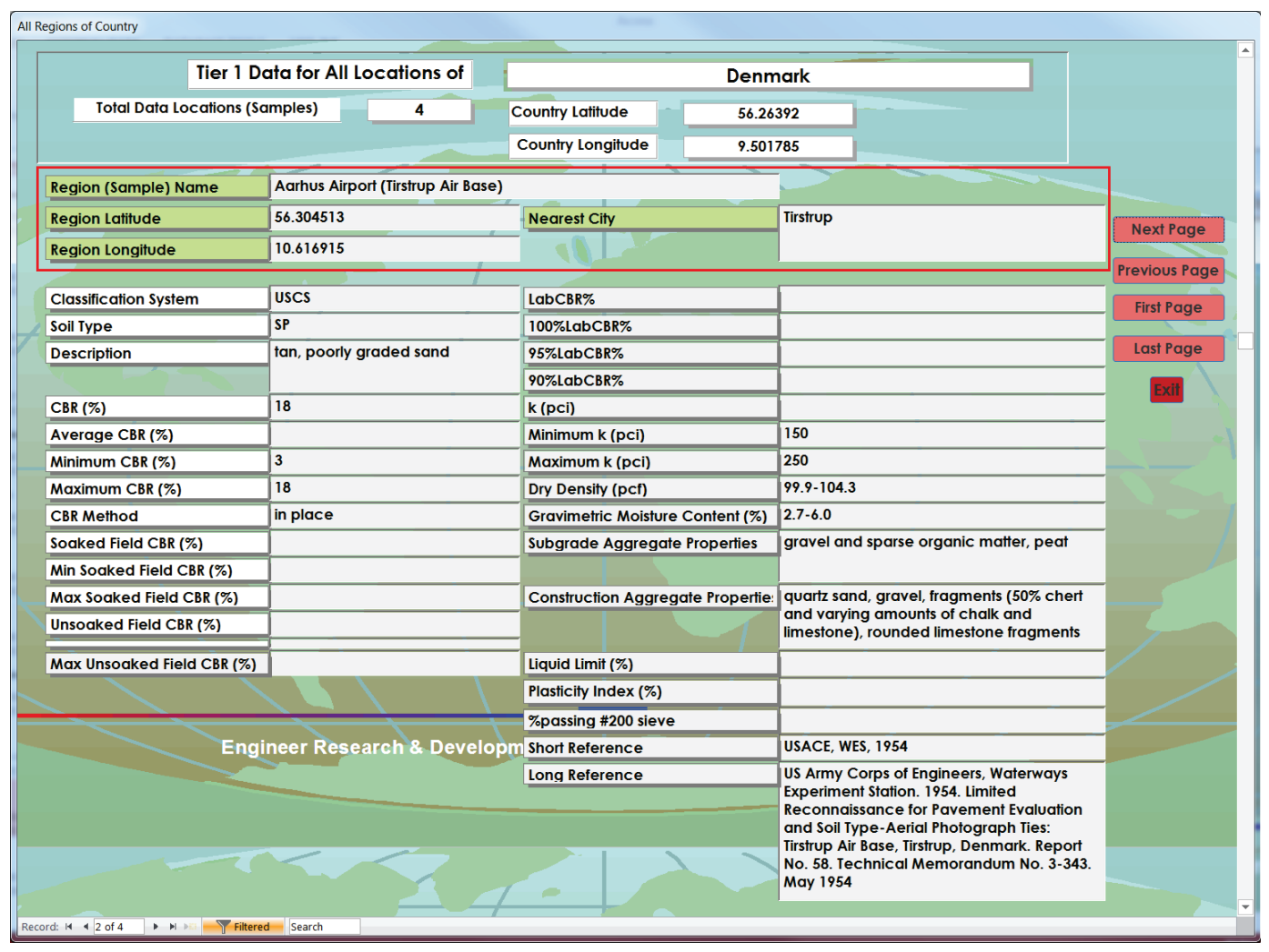

Figure 23. (Cont.)

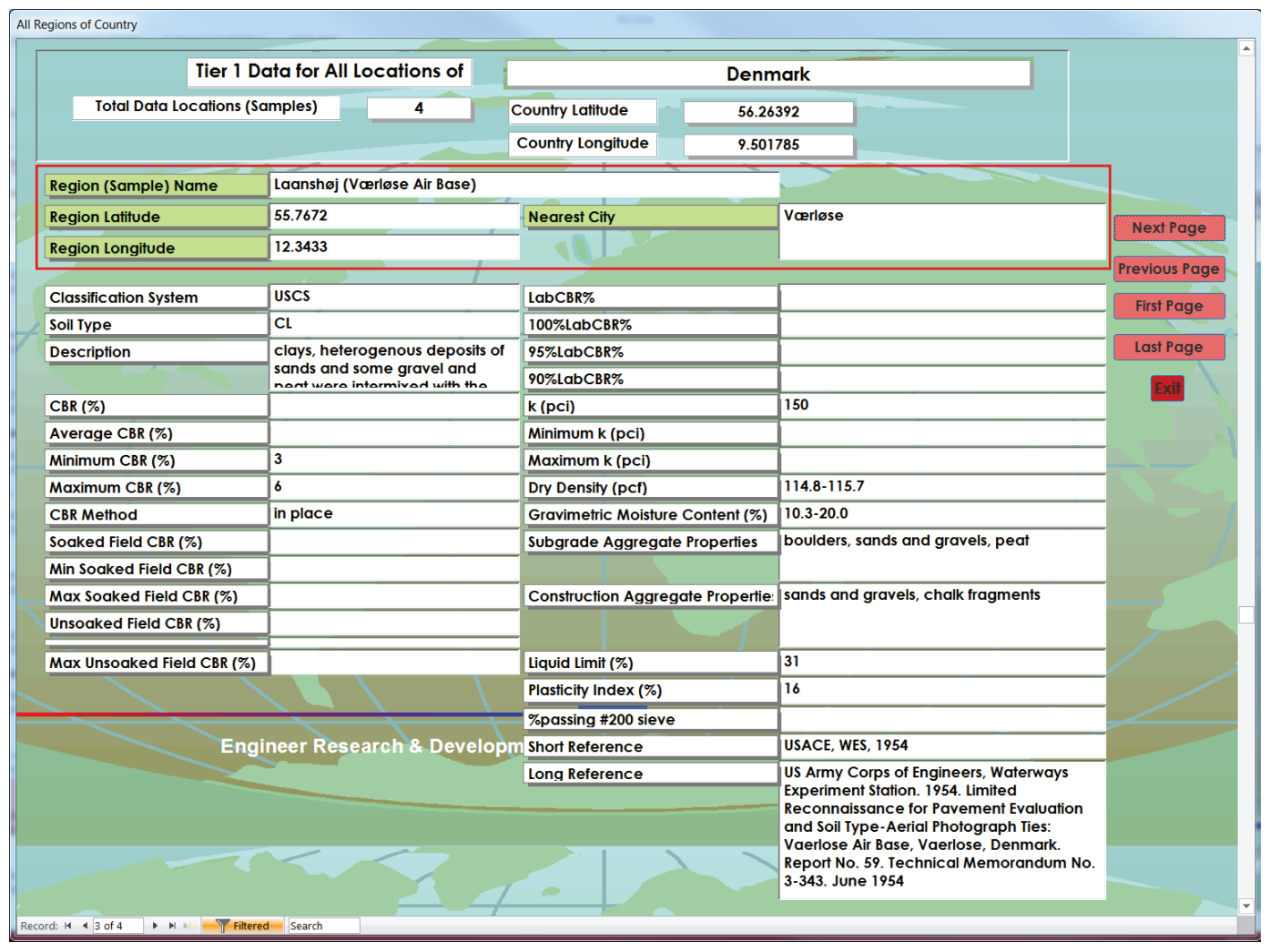


Figure 23. (Cont.)

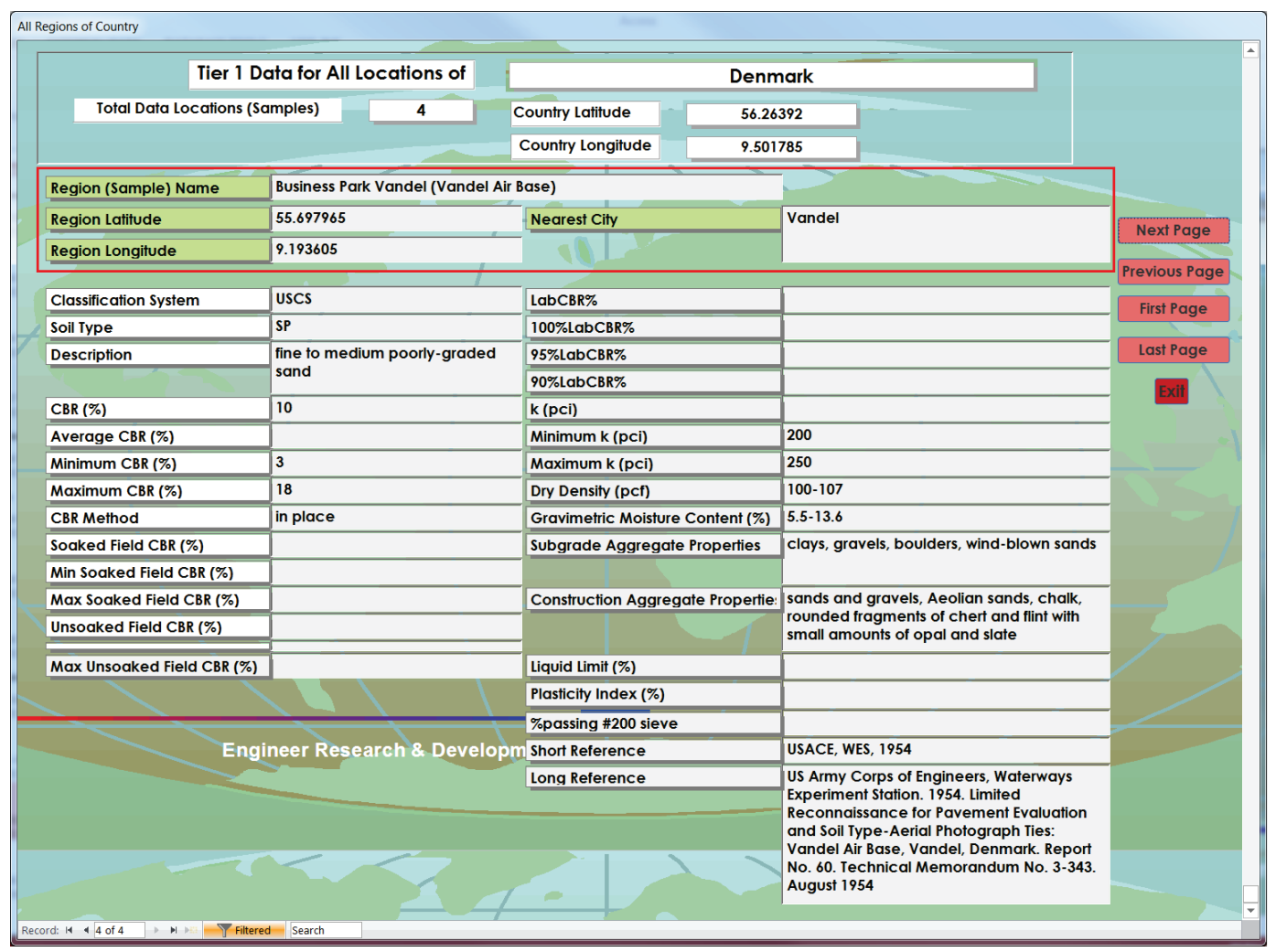

\subsection{Search locations by latitude and longitude}

The database has the option to search for soil data by location using the latitude and longitude of the site. For example, a search was performed for a location with latitude of $32^{\circ}$ and longitude of $7^{\circ}$ (Figure 24). By clicking Search for Locations, the database search options finds two locations in Morocco (Figure 24). The user then can open the data by clicking Open Data in front of the region (site). The results for these two locations are shown in Figure 25 and Figure 26. By knowing the names of these locations, the user then can use other options of the database to get more information and options to print the data or save them in a file. 
Figure 24. Display dialog of search option for a soil data location by latitude and longitude.

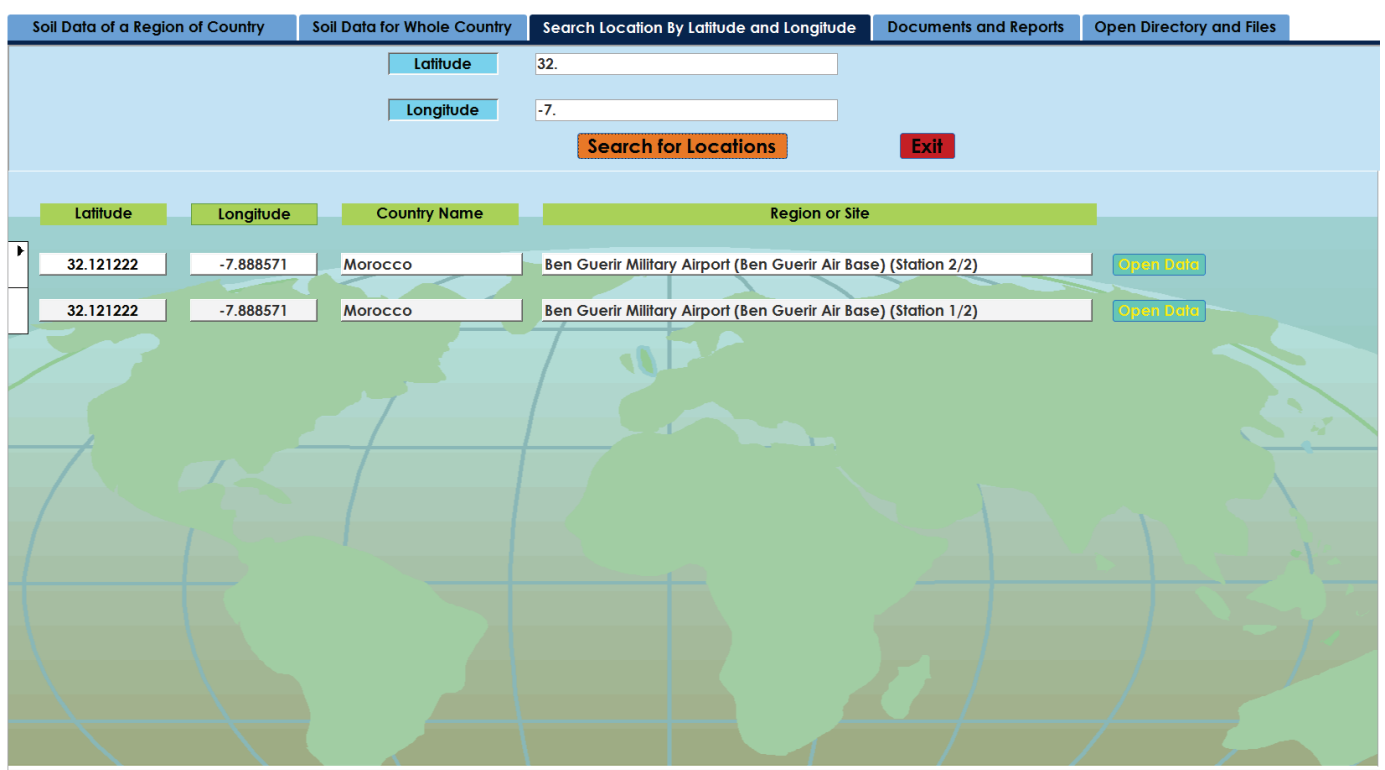

Figure 25. Search result of an example locations, location 1.

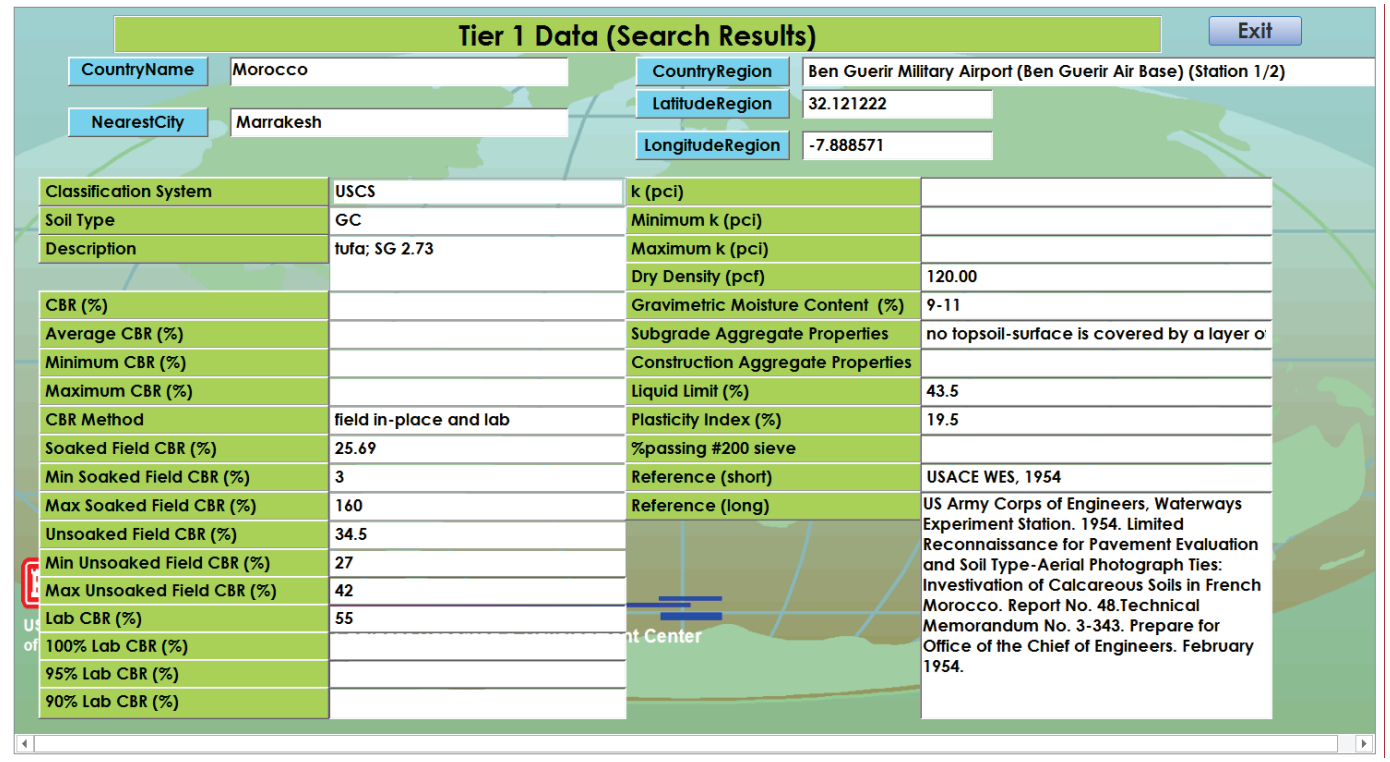


Figure 26. Search result of an example location, location 2.

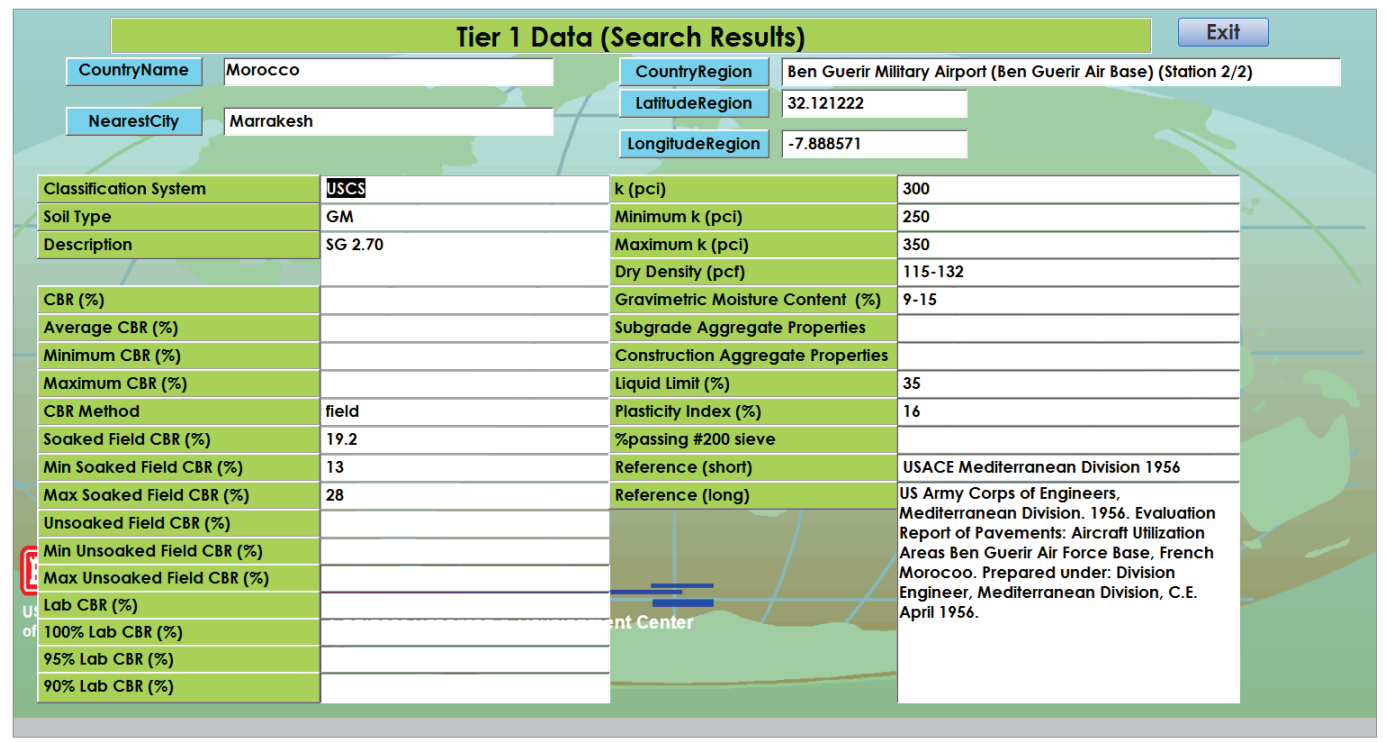

\subsection{Documents and reports}

In addition to this technical report, the user has access to integrated documents and reports in the database. The option for selecting provided documents into the database is under the Documents and Reports option of the main database display dialog. After installing the database, the user must create a directory called $\mathrm{C}: \backslash$ SoilDataBase $\backslash$ Help in the C:

directory of the computer and store provided files in that directory. As an example, the team stored some helpful files in the $\mathrm{C}: \backslash$ SoilDatabsae $\backslash \mathrm{Help}$ directory. By clicking the option Documents and Reports from the main display dialog, the files that can be opened (Figure 27). There is an Exit option to exit this menu. 
Figure 27. Display dialog of the Documents and Reports option.

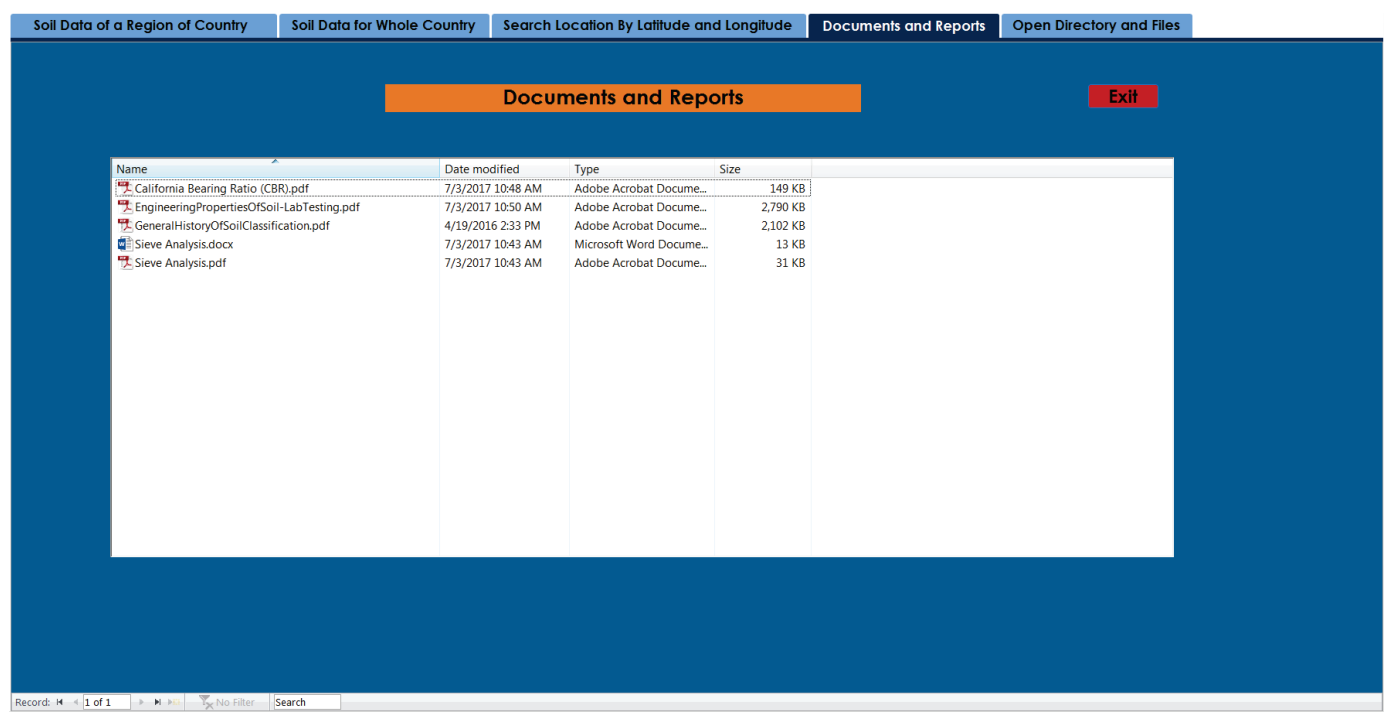

\subsection{Open directory and files}

Another useful option of the database is the Open Directory and Files button. This option in the main menu of the database allows the user to search the computer directory or web sites for more information about the soil data or other information. By selecting Open Directory and Files from the main display dialog of the database, a display window opens as shown in Figure 28. When the user first selects this option, nothing has been selected in File Location or Web Address: the display dialog shows The address is not valid (Figure 28). As the team typed a web address, (e.g., (https://www.defense.gov)), the display dialog shows the website (Figure 29). The user can use the Browse option to search and go to a computer directory and files or click Enter after typing a web address in File Location to open a website (Figure 28). 
Figure 28. Dialog display of Open Directory and Files option of database.

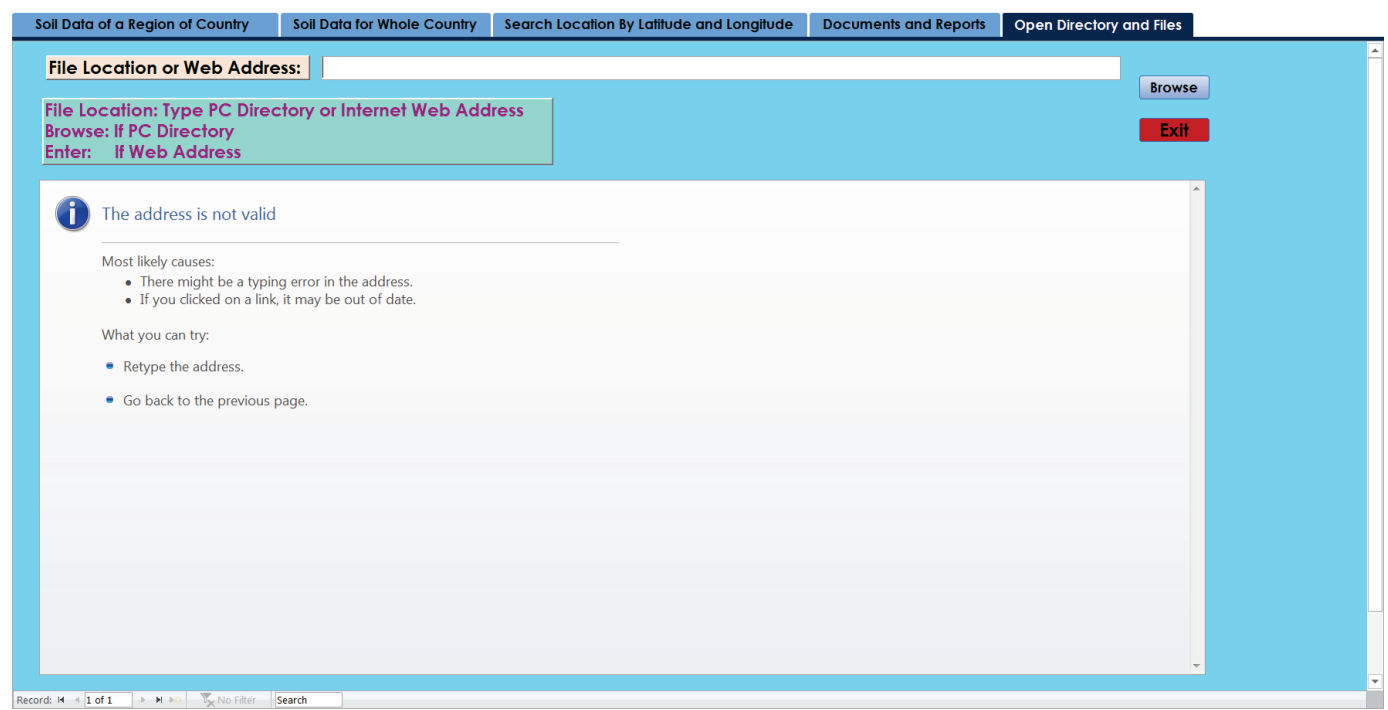

Figure 29. Example of Open Directory and Files option used to open the DoD website.

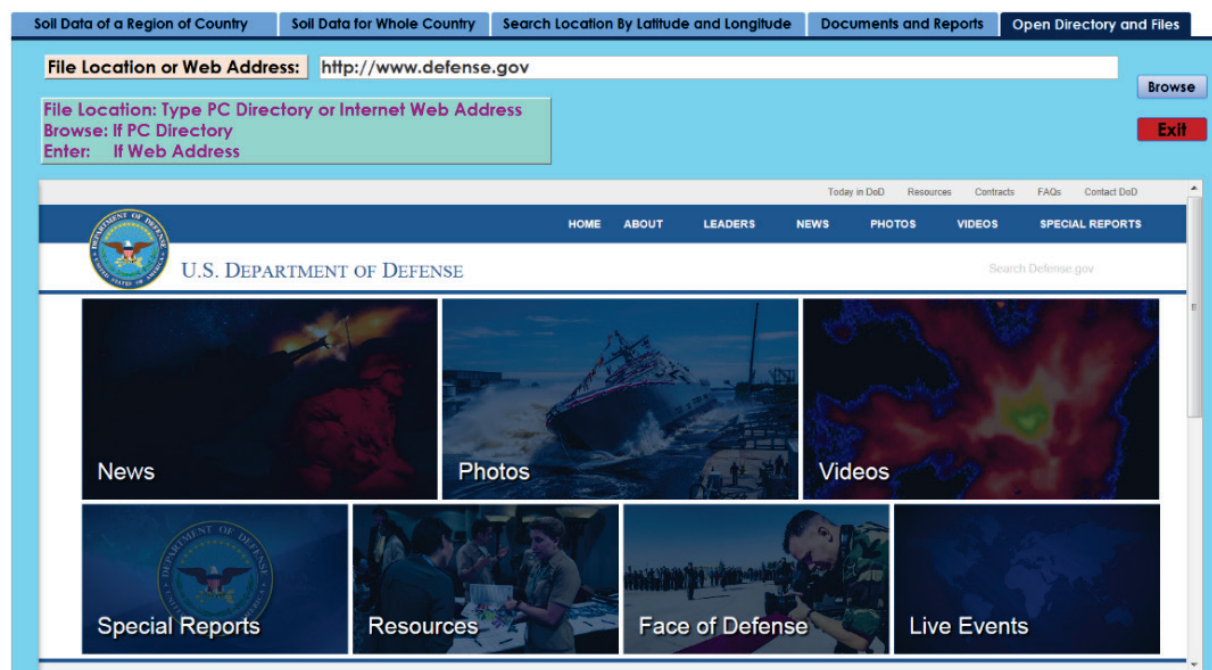

\subsection{General information}

The final option of the database is General Information (Figure 7). This option provides a statistics of number and list of countries with and without data in the database. It also provides list of countries with available and not available Tier 1, Tier 2, and Tier 3 Soil Data in the database (Figure 30). As the database will be added and updated for new data, the general information will change accordingly. 
Figure 30. A dialog display of General Information option.

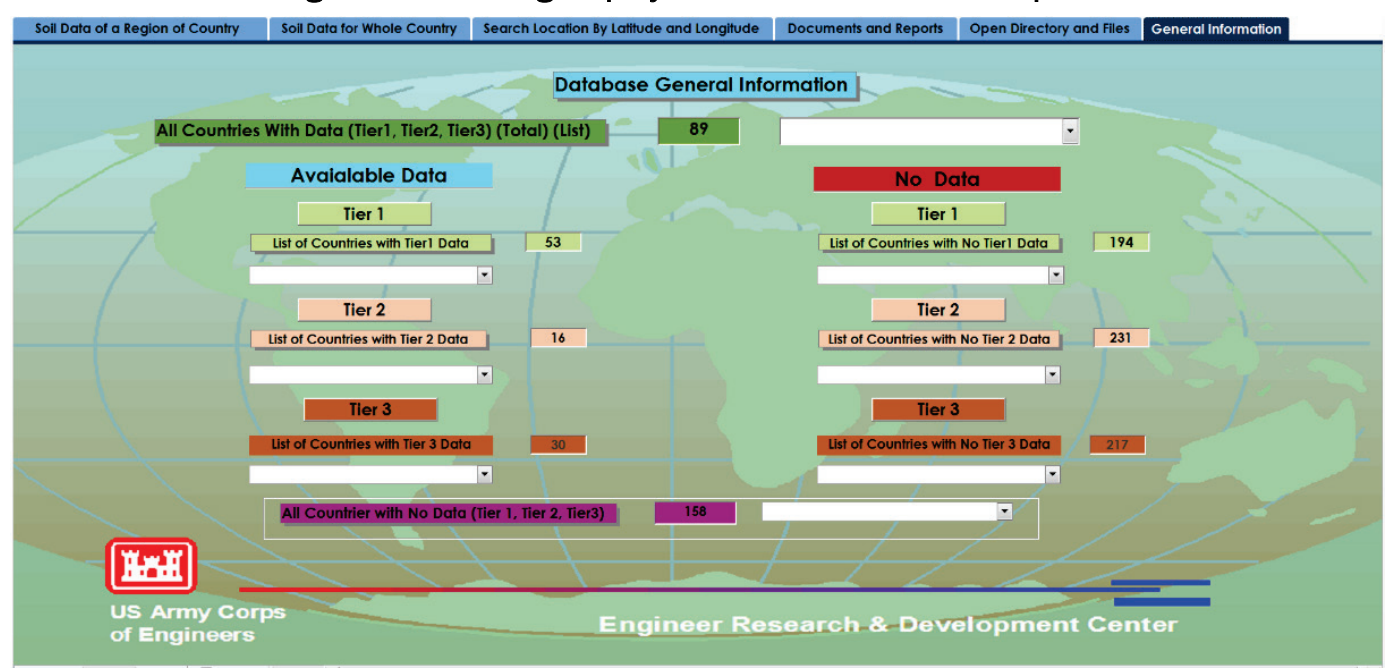




\section{Summary and Conclusions}

Worldwide soil data and databases were collected and reviewed for possible inclusion in a newly developed soil database. The data were ranked according to the credibility of sources and quality of data. The data are included from trusted and verified sources that were labeled as Tier 1 (i.e., ERDC archive soil data and databases) while data from non-verified sources were labeled as Tier 2 and Tier 3. These include data sources such as SSURGO, NSDB, ASRIS, ISRIC, HWSD, ISRIC-WISE, and WRB 2006.

The collected data were integrated into a single, Microsoft Access 2013 standalone database. The MS Access ${ }^{\circledR}$ database and user interface allows for easy access to soil data among the individual data sources and the display of USCS classification soil data or equivalent USCS soil data. The database is very flexible, can be updated easily, and has several useful options including saving the data into a file or printing data for a selected locations. The database has applications for all construction projects involving geo-materials.

The current database is limited to 53 countries of Tier 1 Data, 16 countries of Tier 2 data, and 30 countries of Tier 3 Data. The USA states soil data were available for all U.S. states from the trusted and verified sources (ERDC archive database); however, the data gaps may be added later with Tier 2 or Tier 3 Data. In the database, the USA Tier 1 Data has its selection option and was separated from the data selection option of other world countries.

Using the standalone database described in this report, a web-based tool for accessing the worldwide soil data is under development.

A number of additional tasks should be undertaken to further advance the database for short-term and long-term use:

- Other data sources for all Tier 1, Tier 2 or Tier 3 Data should be sought and added to the database as appropriate and as they become available.

- Experimental measurements should be undertaken for the soil parameters most commonly needed for engineering projects that were not available at the time of this report.

- Existing numerical techniques to convert Tier 3 Data from non-USCS to USCS need to be explored more fully to find out which methods 
provide the greatest accuracy and to determine the degree of error associated with the methods.

- Advances in measurements and computational methods for estimating soil parameters should be explored. 


\section{References}

ASTM International. 2000. Standard Test Methods for Liquid Limit, Plastic Limit, and Plastic Limit, and Plasticity Index of Soils. ASTM D- 4318-00. West Conshohocken, PA: ASTM International.

ASTM International. 2011. Standard Test Method for Expansion Index of Soils. ASTM D4829-11. West Conshohocken, PA: ASTM International.

ASTM International. 2011. Standard Practice for Classification of Soils for Engineering Purposes (Unified Soil Classification System). ASTM D2487-11. West Conshohocken, PA: ASTM International.

Ayers, P., G. Bozdech, J. Freeman, A. Reid, and J. O'Kins. 2011. Development of a Dynamic Visco-Elastic Vehicle-Soil Interaction Model for Rut Depth, Energy and Power Determinations. Presentation to the U.S. Army Research, Development and Engineering Command, Army Tank Automotive Research, Development, and Engineering Center (RDECOM-TARDEC). DTIC ADA548853. Warren, MI: U.S. Army Tank Automotive Research, Development, and Engineering Center.

Batjes, N. H. 2008. Harmonized soil profile data for applications at global and continental scales: Update to the WISE database. (Ver. 3.1). Soil Use and Management 25:124-127. http://doi.org/10.1111/i.1475-2473.2009.00202.x.

Baylot, A. B., M. T. Stevens, J. A. Patterson, G. M. Bandon, and J. G. Green. 2013. Arc-ofInstability and Combatant Command Terrain Geostatistics and Ground Vehicle Mobility Predictions. ERDC/GSL TR-13-3. Vicksburg, MS: U.S. Army Engineer Research and Development Center.

Casagrande, A. 1948. Classification and identification of soils. Transactions of American Society of Civil Engineers 113:901-991.

Cooper, M., L. M. Silveira Mendes, W. Luiz Costa Silva, and G. Sparovek. 2005. A national soil profile database for Brazil available to international scientists. Soil Science Society of America Journal 69:649-652. doi:10.2136/sssaj2004.0140.

Curtis, J. O. 2005. Electromagnetic Poser Attenuation in Soils. ERDC/EL TR-05-5. Vicksburg, MS: U.S. Army Engineer Research and Development Center.

Das, B. M. 2010. Principles of Geotechnical Engineering. $7^{\text {th }}$ ed. Stamford, CT: Cengage Learning, USA.

Das, B. M. and K. Sobhan. 2014. Principles of Geotechnical Engineering. $8^{\text {th }}$ ed. Stamford, CT: Cengage Learning, USA.

Das, B. M. 2016. Principles of Foundation Engineering. SI ed., $8^{\text {th }}$ ed. Boston, MA: Cengage Learning, USA.

FAO/IIASA/ISRIC/ISS-CAS/JRC. 2012. Harmonized World Soil Database (ver. 1.2). FAO, Rome, Italy and IIASA, Laxenburg, Austria. 
Food and Agricultural Organization of the United Nations (FAO). 2006. World Reference Base (WRB) for Soil Resources. A framework for international classification, correlation and communication. Rome, Italy: FAO.

Frankenstein, S. 2014. Fast All Season Soil Strength (FASST) Model Fact Sheet. U.S. Army Corps of Engineers, Engineer Research and Development Center. Hanover, NH. (accessed 20 October 2017), http://www.erdc.usace.army.mil/Media/FactSheets/FactSheetArticleView/tabid/9254/Article/ 476752/fasst-model.aspx

Frankenstein, S., and G. Koenig. 2004. Fast All-Season Soil Strength (FASST). ERDC/CRREL SR-04-1. Hanover, NH: U.S. Army Engineer Research and Development Center.

Garcia-Gaines, R. A., and S. Frankenstein. 2015. USCS and the USDA Soil Classification System. ERDC/CRREL TR-15-4. Hanover, NH: ERDC/CRREL, Hanover, NH: U.S. Army Engineer Research and Development Center.

Hack R., R. Azzam, and R. Charlier. 2004. Engineering Geology for Infrastructure Planning in Europe. Springer-Verleg Berlin Heidelberg, New York. ISBN 0930-0317

Kovacevic, M. S., D. Juric-Kacunic, L. Libric. 2016. Comparison of Unified and European Soil Classification Systems. Sydney, Australia: Australian Geomechanics Society. ISBN 978-0-9946261-1-0.

Liu, T. K. 1967. A review of engineering soil classification systems. Highway Research Record 156:1-22. Washington, DC: National Academy of Sciences.

Mukherjee, S. 2013. The Science of Clays, Applications in Industry, Engineering and Environment. Dordrecht, The Netherlands: Springer.

Oldeman, L. R., and V. W. P. van Engelen. 1993. A world soils and terrain digital database (SOTER)-An improved assessment of land resources. Geoderma 60(1-4):309325, https://doi.org/10.1016/0016-7061(93)90033-H

Skempton, A. W. 1953. The colloidal "activity" of clays, Reprinted from Proceedings of

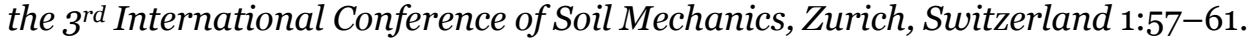

Tingle, J. S., S. L. Tingle, and D. W. Harrelson. 2016. Translating the language of soils: Developing a soil classification system for international engineering projects. GEO-STRATA 20(1):48-52.

U.S. Department of Agriculture (USDA). June 1951. Reconnaissance Soil Survey of Liberia. Agriculture Information Bulletin No. 66, Washington, DC, https://naldc.nal.usda.gov/download/CAT87210307/PDF

1987. Soil Mechanics Level I. Module 3- USDA Textual Soil Classification, Study Guide. Washington, DC: U.S. Department of Agriculture, National Employee Development Staff Soil Conservation Service. Revised February 1987.

1987. Soil Mechanics Level I. Module 2- USDA Textual Soil Classification, Study Guide. Washington, DC: U.S. Department of Agriculture, National Employee Development Staff Soil Conservation Service. Revised February 1987. 
. 1990. Engineering Field Manual. Chapter 4. Elementary soil engineering. Washington, DC: U.S. Department of Agriculture, Soil Conservation Service.

van Engelen V. W. P, and J. A. Dijkshoorn. 2013. Global and National Soils and Terrain Digital Databases (SOTER). Procedures Manual Version 2. International Soil Reference and Information Center (ISRIC) Report 2013-4. 


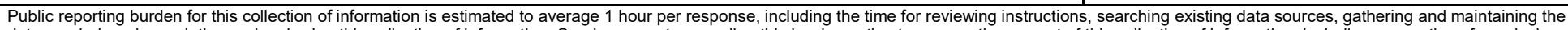

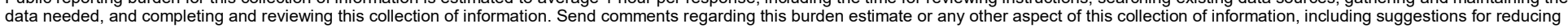

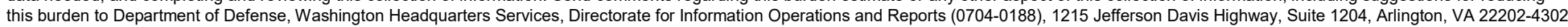

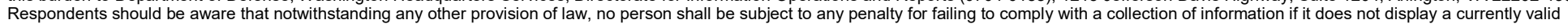
OMB control number. PLEASE DO NOT RETURN YOUR FORM TO THE ABOVE ADDRESS.
1. REPORT DATE (DD-MM-YYYY)
December 2017

\section{TITLE AND SUBTITLE}

Development of an Engineering Soil Database
3. DATES COVERED (From - To)

5a. CONTRACT NUMBER

5b. GRANT NUMBER

5c. PROGRAM ELEMENT

5d. PROJECT NUMBER

6JGGB2

5e. TASK NUMBER

5f. WORK UNIT NUMBER

8. PERFORMING ORGANIZATION REPORT NUMBER

ERDC TR 17-15
U.S. Army Engineer Research and Development Center (ERDC)

3909 Halls Ferry Road, Vicksburg, MS 39180-6199
10. SPONSOR/MONITOR'S ACRONYM(S)

Air Force Civil Engineer Center (AFCEC)

139 Barnes Drive, Tyndall AFB, FL 32403 .

\section{DISTRIBUTION / AVAILABILITY STATEMENT}

Approved for public release; distribution is unlimited.

\section{SUPPLEMENTARY NOTES}

\section{ABSTRACT}

This report describes the development of a standalone engineering soil database that may be used with the design, evaluation, maintenance, and repair of airfields around the world. The soil database was developed using data from different sources. The soil data are divided into three tiers: Tier 1, Tier 2, and Tier 3. Tier 1 Data are soil data that have been measured, collected, and reported by verified U.S. Army Corps of Engineers (USACE) reports based on measurements and testing including the Unified Soil Classification System (USCS). Tier 2 includes data that reports USCS classification, but the data have been collected from non-verified sources such as other non-USACE reports, web sites, and published articles. Tier 3 Data includes data with alternative soil classification systems such as agricultural and geological soil classifications and soil parameters. Tier 3 Data were converted into equivalent USCS classification system. The standalone database described in this report is being converted to a web-based tool for technology transfer. At the time of publication, the database includes Tier 1 Data for 53 countries, Tier 2 data for 16 countries, and Tier 3 Data for 31 countries. The database will be updated periodically as additional data sources are identified and verified.

\section{SUBJECT TERMS}

$\begin{array}{lll}\text { Soils } & \text { Databases } & \text { Air bases } \\ \text { Soils - classification } & \text { Database design } & \end{array}$

Soils - classification Database design

16. SECURITY CLASSIFICATION OF:$$
\text { . }
$$

a. REPORT

Unclassified

\section{b. ABSTRACT \\ Unclassified}

\section{c. THIS PAGE \\ Unclassified}

\section{LIMITATION} OF ABSTRACT

SAR
18. NUMBER OF PAGES

77 19a. NAME OF RESPONSIBLE PERSON

19b. TELEPHONE NUMBER (include area code) 